\author{
UNIVERSIDADE DE SÃO PAULO \\ ESCOLA DE COMUNICAÇÃO E ARTES \\ PROGRAMA DE PÓS-GRADUAÇÃO EM CIÊNCIA DA INFORMAÇÃO
}

O Profissional da Informação e a Gestão da Qualidade em

Serviços de Informação: Capacitação e Mercado de Trabalho

Danielle Thiago Ferreira

Orientador: Prof. Dr. Waldomiro de Castro Santos Vergueiro

São Paulo

2007 


\section{Danielle Thiago Ferreira}

\section{O Profissional da Informação e a Gestão da Qualidade em}

Serviços de Informação: Capacitação e Mercado de Trabalho

Tese apresentada ao Programa de Pósgraduação em Ciência da Informação, Área de Concentração: Cultura e Informação, Linha de Pesquisa: Acesso à informação, da Escola de Comunicação e Artes da Universidade de São Paulo, como exigência parcial para a obtenção do Título de Doutor em Ciência da Informação.

Orientador: Prof. Dr. Waldomiro de Castro Santos Vergueiro

\section{São Paulo}


Catalogação na fonte

FERREIRA, Danielle Thiago.

O Profissional da Informação e a Gestão da Qualidade em

Serviços de Informação: Capacitação e Mercado de Trabalho/

Danielle Thiago Ferreira. São Paulo: [s.n.], 2007.

o0of.

Tese (Doutorado) - Escola de Comunicação e Artes/USP, 2006.

Orientador: Prof. Dr. Waldomiro de Castro Santos Vergueiro

1. Profissional da Informação 2. Gestão da Qualidade 3. Serviços de Informação I. Vergueiro, Waldomiro de Castro Santos II.Título. 


\section{Danielle Thiago Ferreira}

\section{O Profissional da Informação e a Gestão da Qualidade em Serviços de Informação: Capacitação e Mercado de Trabalho}

Tese defendida e apresentada ao Programa de Pós-graduação em Ciência da Informação, Área de Concentração: Cultura e Informação, Linha de Pesquisa: Acesso à informação, da Escola de Comunicação e Artes da Universidade de São Paulo, como exigência parcial para a obtenção do Título de Doutor em Ciência da Informação sob a orientação do Prof. Dr. Waldomiro de Castro Santos Vergueiro.

Aprovada em 12 de junho de 2007.

\section{Banca Examinadora}

Orientador: Prof. Dr. Waldomiro Vergueiro

Profa. Dra. Rose Longo

Profa. Dra. Valéria Valls

Profa. Dra. Dayse Noronha

Prof. Dr. Fernando Modesto 
À minha linda Raíssa, Que, desde a barriga, me acompanha nessa trajetória! 


\section{AGRADECIMENTOS}

A toda a minha Família, em especial aos meus pais, pelo incentivo na construção da minha vida pessoal, acadêmica e profissional e ao Dmitri, pelo amor, apoio e compreensão.

A todos os meus amigos de modo geral e, em especial, ao meu amigo Leonardo Fernandes Souto e a amiga Elisabete da Cruz Neves, pelo incentivo quanto à realização do meu Doutorado.

Ao Prof. Dr. Waldomiro Vergueiro pela orientação, apoio, acompanhamento e dedicação indispensáveis para a construção deste trabalho!

A todos os meus amigos do Sistema de Bibliotecas da Unicamp.

Aos amigos, alunos e professores, da Faculdade de Ciência da Informação da PUC-Campinas.

À Profa. Dra. Valéria Valls, pelo apoio, incentivo e sugestões no decorrer desta pesquisa.

Aos Profissionais da Informação, sujeitos desta pesquisa.

À Sinara Barbanti, pelo trabalho dedicado na revisão gramatical.

A todos que, direta ou indiretamente, ajudaram-me na conclusão deste trabalho. 
"O esforço da qualidade começa na preparação das pessoas."

A. Feigenbaum

"Aprender é a única coisa de que a mente nunca se cansa, nunca tem medo e nunca se arrepende." Leonardo da Vinci 


\title{
O Profissional da Informação e a Gestão da Qualidade em Serviços de Informação: Capacitação e Mercado de Trabalho
}

\begin{abstract}
RESUMO
Esta pesquisa propôs-se a analisar a capacitação do Profissional da Informação na área de Gestão da Qualidade em Serviços de Informação, para tanto foi verificado, por meio de uma pesquisa de campo, o nível de atuação do Profissional da Informação, bibliotecário, na área de Gestão da Qualidade em Serviços da Informação em empresas e também foram pesquisados e identificados as ofertas de cursos stricto e lato-sensu com foco na Gestão da Qualidade em Serviços de informação. Refletiu-se sobre as carências no processo de formação e qualificação do Profissional da Informação e inserção no mercado, analisando-se as exigências de conhecimentos baseados nos estudos internacionais da Special Libraries Association, SLA, competências essas voltadas para a Gestão da Qualidade. Concluiu-se que a pesquisa de campo confirmou a demanda do profissional por capacitação na área da qualidade. Com relação às buscas por ofertas de capacitação, foi possível constatar a diversidade de formas do profissional adquirir este conhecimento, mas também se demonstrou a importância de a Ciência da Informação oferecer tal formação em seus cursos de Pós-graduação.
\end{abstract}

Palavras-chave: Profissional da Informação; Gestão da Qualidade em Serviços de Informação; Profissional da Informação - Mercado de Trabalho. 
The Information Professional and the Quality Management in Information

Services: Qualification and Market Place.

\begin{abstract}
This research analyzed the Information Professional in the Quality Management in Information Services, for this, was verified through a field research the level of performance of the information professional, librarian, in the Quality Management in Information Services in companies and it was also searched and identified. It offers courses stricto and broad sensu with focus in the Quality Management in information services. It was reflected on the lacks, in the formation process and qualification of the information professional and insertion in the market, analyzing the requirements of based knowledge in the international studies of the Special Libraries Association, SLA (1996; 2003), abilities these directed to the Quality Management. Concluded that, the field research confirmed the demand for qualification in quality area, exactly the professional to demonstrate that already acts with sights to the quality in services. With regard to the searches for qualification offers, the diversity of forms to the professional can be evidenced to acquire this knowledge, but it also demonstrated importance of the Information Science to offer such formation in its courses after graduation.
\end{abstract}

Key-words: Information Professional; Quality Management in Information Services; Information Professional -Market Place. 


\section{SUMÁRIO}

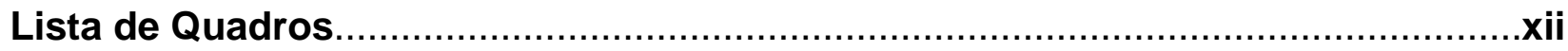

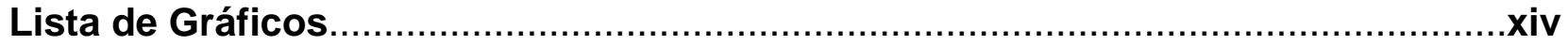

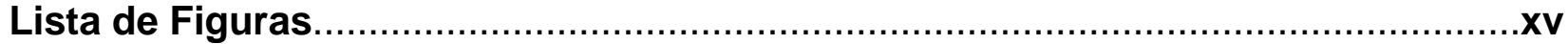

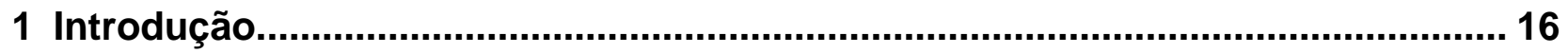

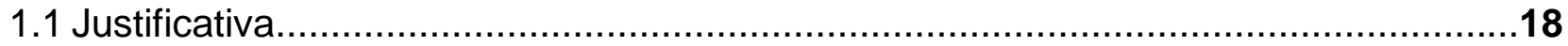

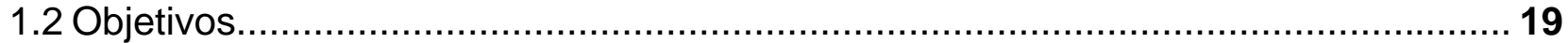

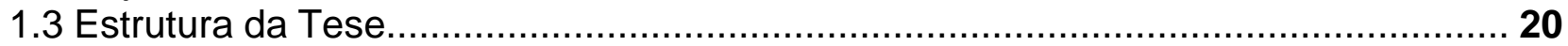

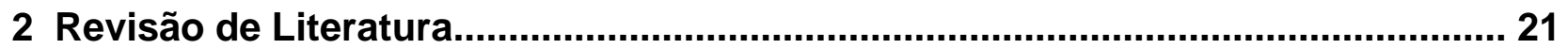

2.1 Reflexão sobre o Profissional da Informação e a atual sociedade ..............................22

2.2 A Gestão da Informação e a Gestão da Qualidade.............................................. 24



2.2.2 Gestão da Qualidade: Conceitos e Fundamentos............................................ 26

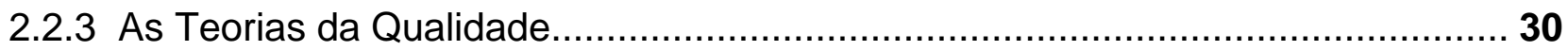

2.2.4 Gestão da Qualidade em Serviços de Informação............................................. 34

2.3 O Mercado de trabalho do Profissional da Informação............................................. 43

2.3.1 As novas funções e o perfil dos Profissionais da Informação................................51

2.3.2 A formação e as competências do Profissional da Informação

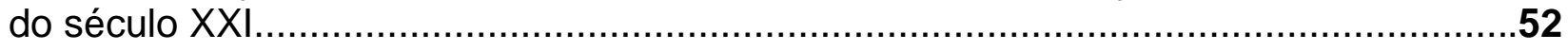

2.4 Educação continuada e o Profissional da Informação............................................61 6

2.4.1 Mudanças no padrão de qualificação do Profissional da Informação:

intercâmbios de conhecimento e desenvolvimento curricular .......................................64 64

3 Metodologia



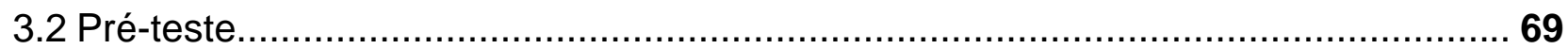

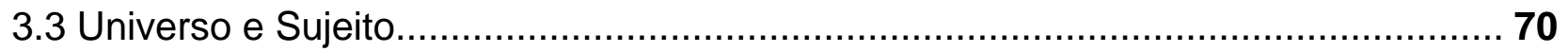

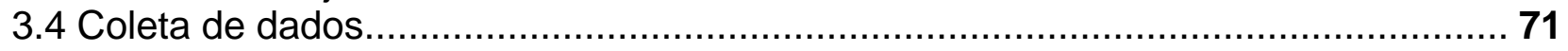

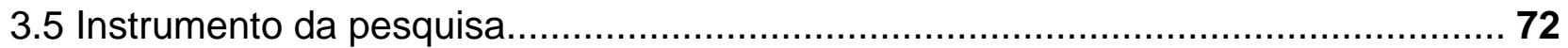

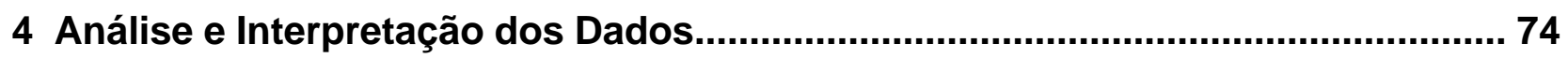

4.1 Pesquisa sobre a atuação do Profissional da Informação....................................... 75

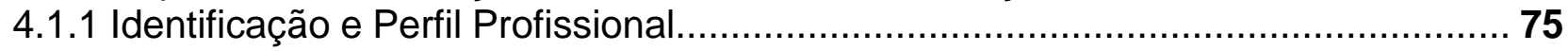

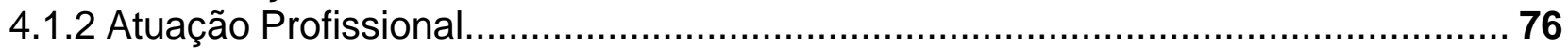

4.1.3 Avaliação dos usuários e os serviços prestados.............................................. 77

4.1.4 Trabalho voltado para os conceitos básicos visando à Qualidade......................... 78

4.1.5 Técnicas e programas da Qualidade utilizadas................................................. 79

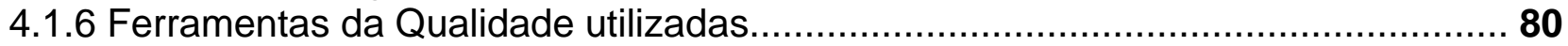

4.1.7 Nível de preparação pessoal para aplicação dessas técnicas, programas e 


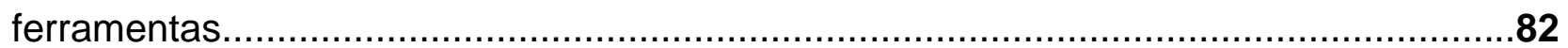

4.1.8 Conhecimento específico para se trabalhar com vista para a Qualidade.............84

4.1.9 Cursos realizados para a atuação profissional.............................................85

4.1.10 Disponibilidades para a educação continuada....................................... 86

4.1.11 Competências para atuar no Serviço de Informação neste novo cenário e a Gestão da Qualidade............................................................... 89

4.1.11.1 Competências Técnicas.............................................................89

4.1.11.2 Competências Pessoais............................................................... 91

4.2 Pesquisa sobre as ofertas de educação continuada e

cursos de Pós-graduação na área da Qualidade............................................94

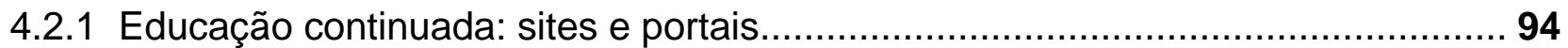

4.2.2 Ciência da Informação: Cursos Lato-sensu e Stricto-sensu

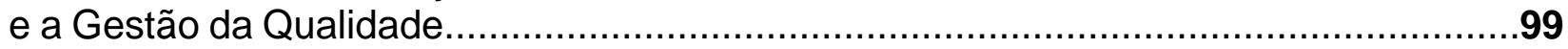

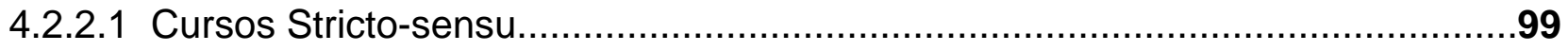

4.2.2.2 Cursos Lato- sensu em Qualidade voltados para Serviços de

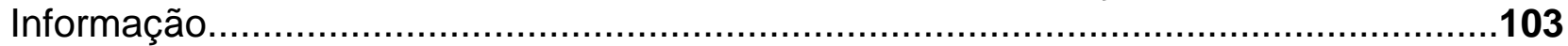

4.2.2.3 Cursos Lato-sensu na área da Qualidade.......................................107

4.2.2.4 Cursos com menos de 360 horas....................................................111

4.2.2 Cursos stricto-sensu na área de Ciência da Informação: conteúdos voltados

para a Gestão da Informação e Gestão de Serviços de Informação........................ 113

4.2.3 Reflexão sobre o currículo básico dos cursos de Graduação

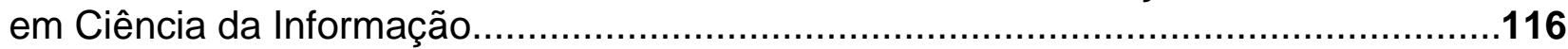

5 Conclusões e Recomendações...................................................................... 118

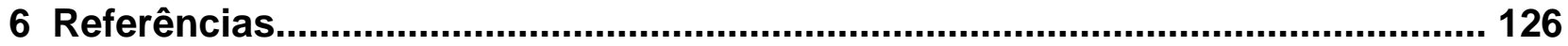

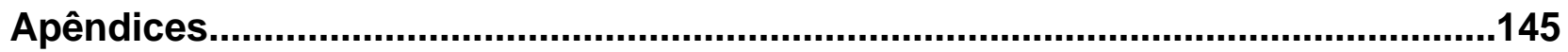

APÊNDICE 1: Questionário

APÊNDICE 2: Carta de Apresentação

APÊNDICE 3: Carta de Agradecimento

Anexos

ANEXO 1: MEC- Proposta de diretrizes curriculares - Ciência da Informação

ANEXO 2: Pós-graduação - Strictu-Senso - Ciência da Informação

ANEXO 3: Pós-graduação - Latu-Senso 


\section{LISTA DE QUADROS}

Quadro 1: Qualidade: definições clássicas...............................................................27

Quadro 2: Evolução do Controle da Qualidade.................................................32

Quadro 3: Trabalhos sobre a aplicação da Gestão da Qualidade

em Serviços de Informação.

Quadro 4: Principais estudos internacionais sobre o mercado de trabalho do Profissional da Informação.

Quadro 5: Principais estudos brasileiros sobre o mercado de trabalho do Profissional da Informação.

Quadro 6: Relação das competências técnicas com grau de prioridade $1 \ldots \ldots \ldots \ldots \ldots \ldots \ldots \ldots . . . . . . . . .90$

Quadro 7: Relação das competências técnicas com grau de prioridade $2 \ldots \ldots \ldots \ldots \ldots \ldots \ldots \ldots . . . . . . . . .90$

Quadro 8: Relação das competências pessoais com grau de prioridade 1 .....................92

Quadro 9: Relação das competências pessoais com grau de prioridade 2 .....................92

Quadro 10: Consultorias relacionadas à Qualidade...........................................96

Quadro 11: Cursos e treinamentos relacionados à Qualidade ..................................97

Quadro 12: Universidade Federal de Santa Catarina -

Programa de Pós-Graduação em Ciência da Informação

Quadro 13: USP / ECA - Programa de Pós-Graduação em

Ciência da Informação (início deste programa em 2006).

Quadro 14: UNB - Programa de Pós-Graduação em

Ciência da Informação e Documentação.

Quadro 15: Faculdade de Sociologia e Política de São Paulo /FESP -

Curso de Especialização "Gerência de sistemas e serviço de informação".

Quadro 16: Universidade Central Paulista- UNICEP/ São Carlos

MBA em Gestão de Unidades de Informação.

Quadro 17: Centro Universitário Augusto Motta -UNISUAM Curso de Especialização em Sistema de Informação e Qualidade Total.

Quadro 18: Universidade Estácio de Sá - Sistemas de Qualidade e produtividade Foco em Sistemas para Gestão Integrada. 
Quadro 19: UNICAMP - Faculdade de Engenharia Mecânica /Mestrado

Profissional - Gestão da Qualidade Total...........................................................109

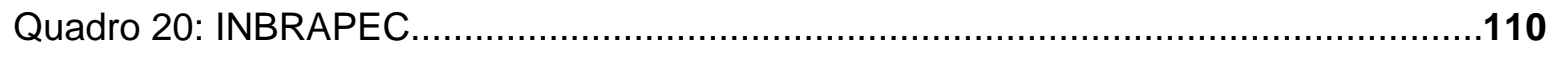

Quadro 21: Cursos sobre Gestão da Qualidade com menos de 360 horas....................112

Quadro 22: Proposta de diretrizes curriculares do MEC

para a área da Ciência da Informação..................................................................... 116 


\section{LISTA DE GRÁFICOS}

Gráfico 1: Serviços de informação..................................................................

Gráfico 2: Métodos para avaliação dos Serviços de Informação.............................78

Gráfico 3: Técnicas da Qualidade utilizadas nos Serviços de Informação ............80

Gráfico 4: Ferramentas da Qualidade utilizadas no Serviço de Informação............81

Gráfico 5: Métodos de capacitação para atuar com Gestão da Qualidade

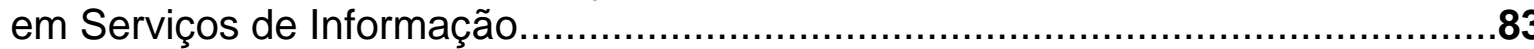




\section{LISTA DE FIGURAS}

Figura 1: Exemplo de web site que caracteriza um Portal relacionado à Gestão do Conhecimento e da Qualidade.

Figura 2: Exemplo de web site que caracteriza serviço de Consultoria relacionado à Qualidade.

Figura 3: Exemplo de web site que caracteriza treinamentos relacionados à Qualidade. 
1 Introdução 
A discussão sobre a formação do Bibliotecário ou Profissional da Informação no país está sempre em xeque, carecendo de olhar crítico de quem a faz ou com ela se relaciona, a fim de superar, melhorar e fazer avançar o modo com que está sendo feita. Como exercer este olhar crítico é uma das preocupações recorrentes dos pesquisadores da área e, particularmente, desta pesquisa.

A pesquisa por mim elaborada, na ocasião do Mestrado, mostrou o reconhecimento do Profissional da Informação, pelo mercado de trabalho, mas não a do profissional advindo da área da Ciência da Informação; assim sendo, recomendou que houvesse o diálogo entre as Instituições formadoras, as entidades de classe e os empregadores do Profissional da Informação, para estudarem as formas ou pontos a serem trabalhados para seu efetivo reconhecimento, visto que o problema principal parece estar na ausência do diálogo entre esses segmentos (FERREIRA, 2002b).

Diante deste problema e focando esta pesquisa para o profissional atuante, busquei então traçar uma meta de pesquisa que trabalhasse com a avaliação da atuação em setores em que o Profissional da Informação deve estar presente, como a área da Gestão da Qualidade, diretamente ligada à Administração da Informação, quando do trabalho deste profissional no mercado emergente ou empresarial.

Como problema desta pesquisa, vejo o fato de que o mercado emergente, ou seja, as empresas exigem uma atuação que busca modelos de organização com padrões de qualidade; se o mercado não reconhece este profissional, surge uma dúvida muito crucial: será que ele, ao atuar com a Gestão da Qualidade, está atuando com excelência? Haja vista que tal aspecto é prioritário em empresas. 


\subsection{Justificativa}

A motivação para iniciar esta pesquisa surgiu quando do término do mestrado, com a intenção de continuar com a temática voltada para o Profissional da Informação e o mercado de trabalho. Assim, visto o novo parâmetro do mercado emergente deste profissional, tive a motivação para, nesta pesquisa, estudar a área da Gestão da Qualidade de Serviços de Informação.

Como menciona Vergueiro (2002) "o mundo caminha para a qualidade", os Profissionais da Informação também devem se ajustar a essa nova realidade, levando os programas de qualidade para dentro de seus espaços de trabalho, incluindo os de serviços informacionais. Assim sendo, e, segundo Vanti (1999), sistemas de informações - como por exemplo as bibliotecas -, estão cada vez mais preocupados com um ambiente de qualidade e tentam melhorar sua imagem e serviços administrando-os com eficiência e efetividade, na busca de oferecer produtos e serviços que satisfaçam às necessidades do cliente.

De acordo com Silva (2000), para se chegar a este nível de excelência e de desempenho, o serviço ou sistema de informação "dependerá sempre da qualidade profissional de seu administrador", já que este transforma palavras e idéias em conhecimentos e resultados satisfatórios. Assim, reafirma-se a importância deste trabalho no sentido de verificar e avaliar, na realidade e na prática, a qualificação, a capacitação e o perfil do Profissional da Informação para sua atuação na área da Gestão da Qualidade em Serviços de Informação.

Assim sendo, como hipótese deste trabalho afirmo que: o Profissional da Informação precisa ter capacitação adequada na área de Gestão da Qualidade para atuar no mercado emergente. Para validar tal hipótese, trabalhei os objetivos apresentados a seguir. 


\subsection{Objetivos}

\section{Geral}

Analisar a capacitação do Profissional da Informação, Bibliotecário, na área de Gestão da Qualidade em Serviços de Informação.

\section{Específicos}

- Identificar o nível de atuação do Profissional da Informação, bibliotecário, na área de Gestão da Qualidade em Serviços da Informação.

- Identificar a oferta de educação continuada na área de Gestão da Qualidade em Serviços de Informação.

- Identificar as carências no processo de formação e qualificação do Profissional da Informação e sua inserção no mercado de trabalho, analisando as exigências de conhecimentos técnicos baseados nos estudos internacionais da Special Libraries Association, SLA.

- Refletir sobre o processo de qualificação do Profissional da Informação, que atuará e dos que já atuam em Serviços de Informação em empresas, voltado para a Gestão da Qualidade. 


\subsection{Estrutura da Tese}

A elaboração desta pesquisa, consolidada na apresentação da tese, conta com a seguinte estrutura:

1) Introdução: com as intenções e objetivos da pesquisa, justificativa e estrutura da tese.

2) Revisão de literatura: contando com o estudo exaustivo dos tópicos pertinentes à temática Gestão da Qualidade em Serviços de Informação; mais estudos sobre: o Profissional da Informação e o mercado de trabalho; a Gestão da Informação e a Gestão da Qualidade e o Profissional da Informação: ambiente e atuação neste novo contexto.

3) Análises e discussão: da pesquisa de campo e das buscas de ofertas de educação continuada e cursos de Pós-Graduação pertinentes ao estudo em questão.

4) Conclusões: contendo as considerações e conclusões sobre os conceitos do estudo acerca da pesquisa de campo e ofertas de educação continuada na área da Gestão da Qualidade em Serviços de Informação. São apresentados ao final, além das referências, os anexos e apêndices que completaram e deram base a este estudo. 
2 Revisão de Literatura 
A revisão de literatura desta tese incluiu referencial teórico sobre 0 Profissional da Informação: mercado de trabalho, formação e perfil no atual contexto relacionando-o com a Gestão da Qualidade em Serviços de Informação.

\subsection{Reflexão sobre o Profissional da Informação e a atual sociedade}

Cabe iniciar esta reflexão apontando para o fato de que a sociedade vem passando por grandes mudanças e complementando esta afirmação, Cunha (2000a, p.1) optou por designá-las como sendo, "tecnológicas, econômicas e sociais". Assim, tomando esta realidade como ponto de partida, discute-se, nos próximos itens, essas mudanças e tendências que refletem e refletirão diretamente na atuação do Profissional da Informação. Tais mudanças são cruciais no mundo do trabalho, onde, segundo Ferreira (2002b), tem-se a diminuição da participação da força de trabalho humano voltada às tarefas rotineiras, repetitivas e atividades consideradas não criativas são terceirizadas e tem-se a valorização do capital intelectual e das profissões ditas estratégicas, relacionadas à Gestão da Informação.

Vale destacar que as mudanças que afetam todas as outras profissões intensificam-se quando ligadas às novas tecnologias da informação e as tendências da administração. Portanto, não excluem o Profissional da Informação; ao contrário, necessitam ainda mais de sua atuação.

Com relação às tecnologias, tais mudanças fizeram com que se desenvolvessem novas atividades e novos perfis profissionais. Com tais inovações que pode-se denominar como sendo o ponto de partida dessa nova Era, a Era do Conhecimento e da Informação, que vive em constante mutação, na qual tem-se a certeza de que o profissional precisa estar preparado para enfrentar questões como: lidar com o "acesso" e gerenciar o "excesso" de informações. Este profissional, quando atuante, em qualquer área ou campo de trabalho, precisa estar sempre atento aos novos produtos informacionais e que, por conseqüência, 
influencia nos serviços e nas atividades biblioteconômicas que também serão remodelados.

Com relação à Administração, fala-se na Era do Conhecimento, do Capital Intelectual e da Inteligência Competitiva sob a óptica das organizações (SENGE, 2000; CASTELS, 1999; DRUCKER, 2000; DAVENPORT \& PRUSAK, 1998). que torna o momento atual inédito é o crescimento do investimento intangível mais do que o investimento físico (FERREIRA, 2002b), e a economia e a administração estão cada vez mais baseadas em conhecimento. Isto significa dizer que o ser humano em seu âmbito de atuação deve ser cada vez mais preparado para produzir e gerir conhecimento. Nesta perspectiva, segundo Mattos, (1982, p.21), todas as áreas da organização precisam ser repensadas. Portanto, o atual mundo globalizado exige profissionais cada vez mais qualificados e com habilidades para tomar decisões e para a prática de relações interpessoais.

Diante dessa grande mudança porque passa o perfil do Profissional da Informação, o Bibliotecário, também o seu ambiente de trabalho evoluiu com as novas tecnologias. Segundo Cunha (2000a, p.2), o desenvolvimento da Sociedade de Informação "criou um ambiente que desestabiliza muitas de nossas idéias sobre informação e sua disponibilização". As Unidades de Informação, as Bibliotecas ou os Centros de Informação agora são espaços de compartilhamento e estão abertos para o mundo, através de sistemas, redes e Internet, que como Cronin (1993) retrata são "bibliotecas sem paredes".

Portanto, considerando que informação e conhecimento passam a ser matéria-prima que exigem gerenciamento, e diante de seus conceitos considerados "interdisciplinares" (SARACEVIC, 1995), o Profissional da Informação, Bibliotecário precisa estar atento às exigências de eficácia que envolve o mercado das profissões da Informação. 
Assim, a Ciência da Informação é considerada a área que tem por finalidade estudar os fenômenos acerca da informação e todas as fases de seu ciclo, desde a geração até a sua representação, processamento e disseminação (FERREIRA, 2002b). Portanto, para que o profissional bibliotecário trabalhe com a administração da informação e do conhecimento -- não só em empresas mas em qualquer tipo de organização, -- entende-se que é necessário que o mesmo leve em conta conceitos-chave, tais como: a Gestão da Informação e a Gestão da Qualidade, analisados a seguir.

\subsection{A Gestão da Informação e a Gestão da Qualidade}

\subsubsection{Gestão da Informação}

Fazendo aqui uma breve reflexão sobre essa temática, inicia-se com Dias e Belluzzo (2003), que caracterizam a Gestão da Informação "como um conjunto de conceitos, princípios, métodos e técnicas utilizados na prática administrativa colocada em execução pela liderança de um Serviço de Informação".

Para completar esta definição, sob o ponto de vista operacional, temos também a definição dada por Davenport (1998, p. 173), que trata a Gestão da Informação como um processo definido por "um conjunto estruturado de atividades que incluem o modo como as empresas obtêm, distribuem e usam a informação e o conhecimento".

De acordo com esses autores, a Gestão da Informação possui pontos essenciais para o desenvolvimento de suas políticas que compreendem dentre eles "a importância da qualidade, a produção com criatividade e a satisfação do cliente". Portanto, para que a organização alcance objetivos voltados para a produtividade, competitividade, inovação e desenvolvimento é necessário que se aplique, em seu Serviços de Informação, novos princípios de gestão, como os conceitos da qualidade, da gestão de pessoas e marketing. Isso resulta na 
satisfação dos clientes, na otimização dos resultados, na melhoria da imagem, na agregação de valor a informação e na criação de um ambiente de aprendizado contínuo (DIAS E BELLUZZO, 2003), necessitando, assim, de um profissional que lidere, gerencie e administre com eficiência essa informação.

Segundo Davenport (1998, apud FERREIRA, 2002b), é possível definir um processo de gerenciamento da Informação por meio das seguintes etapas:

1) administração de exigências, em que se combinam as necessidades de informação do usuário e os canais fornecedores;

2) plano de ativos informacionais, em que se classifica a informação, assim que é obtida, de acordo com a confidencialidade, o tempo que ela deve ser mantida e protegida;

3) plano de sistemas informacionais, em que se planeja 0 armazenamento e a distribuição de dados;

4) aquisição, em que se obtém a informação;

5) análise, em que se analisa o conteúdo da informação para estabelecer níveis de confiabilidade, segurança e qualidade;

6) disseminação, etapa em que se distribui a informação aos que dela necessitam ;

7) o feedback, em que se pergunta aos receptores se a informação adequada foi recebida e distribuída de maneira correta, e se foi dado treinamento suficiente quanto ao uso da mesma.

Todavia, o processo de Gestão da Informação em organizações, segundo Davenport (1998), deve passar por melhorias contínuas e aperfeiçoamentos 
constantes que podem fazer o uso das abordagens da qualidade total ou das abordagens ecológicas - mais voltadas para as pessoas.

Segundo Ferreira (2002b), uma das formas de aprimoramento e refinamento do processo de Gestão da Informação que já se destaca é a Gestão do Conhecimento. Wah (2000, p.51) define a Gestão do Conhecimento como sendo uma ferramenta gerencial para administrar o conhecimento e a informação, agregando-lhe valor ao filtrá-la e sintetizá-la, permitindo aos seus utilizadores conseguir a informação necessária para passar à ação.

Este conceito, que evidencia a Gestão do Conhecimento, surgiu no início da década de 1990 (TERRA, 2000; FLEURY \& OLIVEIRA J., 2001) e, a partir de então, as empresas vêm utilizando-o para facilitar o fluxo de informação em seus diversos setores.

Partindo-se agora para o principal foco desta pesquisa há uma outra forma de aprimoramento da Gestão da Informação que seria o uso de conceitos voltados para a qualidade, suas ferramentas e/ou, a gestão baseada na qualidade de serviços, que serão discutidos a seguir.

\subsubsection{Gestão da Qualidade: conceitos e fundamentos}

Cada vez mais, a qualidade de bens e serviços torna-se uma variável fundamental para a capacidade competitiva, ou seja, para que uma organização consiga melhorar a sua competitividade é necessário que ela coloque produtos de qualidade e que estes produtos ou serviços sejam gerados por meio de um processo produtivo que também tenha qualidade. Deve-se buscar a satisfação do cliente, garantindo a preferência aos produtos, portanto, a longevidade dos negócios da empresa. 
Este conceito tornou-se importante nos sistemas produtivos, visto a introdução de técnicas de produção em massa, na década de 1920.

A Gestão da Qualidade implica primeiramente, segundo Dias e Belluzzo (2003), "na compreensão do conceito do termo 'Qualidade' e as situações que o envolvem nas organizações prestadoras de serviços". Outra definição que espelha bem o conceito de qualidade nas organizações é: "a qualidade é a organização como um todo e o seu processo de produção voltada à melhoria contínua" (PALADINI, 2000, p.20).

Ainda com relação ao termo 'Qualidade', Ferreira (1986 apud Valls, 1998), a define como "propriedade, atributo ou condição das coisas ou das pessoas, capaz de distinguí-las das outras e de lhes determinar a natureza".

Existe o que se convencionou chamar de "definições clássicas", citadas por Valls (2005), que compreendem definições de autores como Crosby, Deming, Feigenbaum, Ishikawa e Juran, precursores do tema (OAKLAND, 1994), em que todos as apresentam com diferentes palavras:

\section{Quadro 1: Qualidade: definições clássicas}

\begin{tabular}{|l|l|}
\hline Crosby (1975) & Qualidade é a conformidade do produto às suas especificações. \\
\hline Deming (1985) & $\begin{array}{l}\text { Qualidade é redução da variabilidade. É o caminho para a } \\
\text { prosperidade, por meio do aumento da produtividade, da redução } \\
\text { de custos, da conquista de mercados e da expansão do } \\
\text { emprego. }\end{array}$ \\
\hline Ishikawa (1988) & $\begin{array}{l}\text { Qualidade é desenvolver, projetar, produzir e comercializar um } \\
\text { produto que seja sempre mais econômico, mais útil e sempre } \\
\text { satisfará o consumidor. }\end{array}$ \\
\hline Juran (1991) & $\begin{array}{l}\text { A qualidade consiste nas características do produto que vão ao } \\
\text { encontro das necessidades dos clientes, proporcionando a } \\
\text { satisfação em relação ao produto; é a ausência de falhas. }\end{array}$ \\
\hline Feigenbaum (1994) & $\begin{array}{l}\text { Qualidade é a correção dos problemas e de suas causas ao } \\
\text { longo de toda série de fatores relacionados com marketing, } \\
\text { projetos, engenharia, produção e manutenção, que exercem } \\
\text { influência sobre a satisfação do usuário. }\end{array}$ \\
\hline
\end{tabular}

Fonte: Moretti, 2003. 
Outra definição é dada pela NBR ISO 9000 (ABNT, 2000, p. 8), que a define como "conjunto de atividades coordenadas para dirigir e controlar uma Organização, no que diz respeito à qualidade".

Atualmente, a grande competição econômica e as intensas inovações tecnológicas são fatores que impulsionaram as empresas a buscar a implementação de Sistemas de Gestão da Qualidade, para melhorar o oferecimento de seus produtos e serviços.

O Homem da sociedade moderna é completamente diferente na sua forma de pensar e de agir ou de se comportar, em outras palavras, pode-se dizer que está surgindo o "homem qualitativo", mais do que nunca preocupado com a qualidade, seja ela de vida, de produtos ou serviços. Neste sentido, segundo Vergueiro (2002), "nunca antes essas questões estiveram tão presentes nas preocupações dos seres humanos". Assim, o autor completa dizendo que:

A busca da qualidade é provavelmente uma das características da segunda metade do Século XX. A Qualidade dos produtos maciçamente produzidos e comercializados, buscando atender a um mercado que cada vez mais desconhece fronteiras territoriais. Qualidade dos serviços recebidos das mais diversas organizações, como hotéis, lojas de departamento...Qualidade da prestação de serviços das categorias profissionais antes pouco questionadas, como advogados, professores, médicos, engenheiros, bibliotecários. Qualidade do meio ambiente em que se vive, encarado agora de maneira muito mais sistêmica e globalizante, com os limites territoriais cada vez menos decisivos no relacionamento internacional. Qualidade das atividades de lazer, vistas como iniciativas em busca de se obter o máximo de benefício para o tempo livre disponível. (p.11)

De acordo com Barbedo e Turrioni (2003), a "obtenção da qualidade no setor de serviços pode ser vista como um processo contínuo e o cliente é membro fundamental para o reconhecimento das organizações na comunidade a que esta serve", suas necessidades, satisfeitas ou não, podem "determinar o prestígio e sobrevivência de uma organização dentro do mercado". Assim, houve a necessidade das empresas terem um sistema de garantia da qualidade implantado, que dê confiabilidade ao cliente de que o produto é fabricado de acordo com as especificações previamente aceitas ou abordadas. E esta 
necessidade levou os países europeus a criarem uma série de normas de garantia da qualidade, hoje mundialmente aceitas e conhecidas como as normas internacionais ISO Série 9000.

Segundo Luz (2002), a ISO 9000 é um conjunto de normas que estabelece direcionamento para a implementação de um Sistema de Gestão da Qualidade. E esse conjunto é baseado em oito princípios (ABNT, 2000) focados no processo de melhoria de uma organização, são eles: foco no cliente, liderança, envolvimento de pessoas, abordagem de processo, abordagem sistêmica para a gestão, melhoria contínua (global), abordagem factual para tomada de decisão e benefícios mútuos nas relações com os fornecedores.

Diante desses conceitos, entende-se que a Gestão da Qualidade traz benefícios para toda a organização, desde sua comunidade interna até a externa seus clientes - e engloba melhorias em todos as dimensões, sejam econômicas, ambientais e sociais. Assim, para entender mais o assunto, o próximo item enfocará as teorias e histórico da qualidade, destacando sua evolução. 


\title{
2.2.3 As Teorias da Qualidade
}

A respeito do termo "qualidade", no âmbito das Ciências Administrativas, foram instituídas as mais diversas teorias, e essa variedade ocorre, segundo Vergueiro (2002), "porque cada um de seus idealizadores encara o ambiente organizacional de maneira ligeiramente particular", pois "cada teórico da qualidade defende a adoção de estratégias próprias". Assim sendo, estudiosos como: Fayol, Mayo, Deming, Juran, Ishikava, Crosby, Peters, Imai e Fiegenbaum pesquisaram e instituíram propostas de aplicação dessas teorias.

Vergueiro (2002, p.19) continua sua afirmação a respeito das denominações sobre as teorias da qualidade, dizendo que:

\begin{abstract}
todas elas devem sua gênese à evolução do pensamento teórico da ciência administrativa, que a partir de um determinado momento, buscou considerar o ambiente no qual as tomadas de decisão deveriam ocorrer e, desta forma, adequar o processo de administração às características do momento histórico e às peculiaridades de sua clientela.
\end{abstract}

De acordo com Valls (2005), da administração cientifica à gestão por processos foi traçado um longo caminho que contribuiu para a evolução do conceito da Gestão da Qualidade, ampliando sua aplicabilidade nos mais diversos tipos de organizações.

A gestão de processos compreende um instrumento na melhoria contínua na qualidade relacionada a uma seqüência de tarefas e atividades utilizadas na entrada (input), que gera uma saída (output) para um cliente específico, interno ou externo, gerando resultados concretos. Além disso, os processos necessitam da retro-alimentação (feedback) que viabiliza mudanças significativas na condução dos mesmos (REIS e BLATTMAN, 2004). 
Para relatar um pouco da evolução da Gestão da Qualidade, seguem as principais características do histórico desta evolução, baseados no trabalho de perspectiva histórica do conceito da qualidade, feito por Valls (2005, p.21):

a) No início do século $X X$, tem-se a publicação do livro "Princípios da Administração Cientifica" de Taylor (1911).

b) Em 1922 e 1923, Radford e Shewart publicaram livros sobre o controle de qualidade em manufatura.

c) De 1938 a 1945, foram publicados padrões de qualidade e Deming atua como consultor.

d) Em 1947, foi fundada a ISO - International Organization for Standardization com o objetivo de padronizar rotinas industriais.

e) A década de 50 foi um período importante para a evolução dos conceitos da qualidade, quando, por exemplo, foi publicado o primeiro padrão da ISO, e Deming, Juran e Feigebaum começaram suas atividades de treinamento e consultoria no Japão.

f) Nas décadas de 60 a 90, houve a consolidação de difusão das idéias ocidentais no Japão, sobre a gestão, o sistema e o controle estatístico da qualidade. Neste período, destaca-se Kaoru Ishikawa considerado uns dos importantes autores sobre o tema.

g) No século XXI, a ISO publicou a série ISO 9000 versão 2000, fazendo com que os Sistemas de Qualidade das empresas que tivessem certificação migrassem para esta nova versão.

Para complementar os históricos da qualidade, no quadro 2, apresenta-se uma evolução do controle de qualidade feita por Feigenbaum (1994) através de etapas que distinguem por quem eram feitos esses controles, até chegar aos dias atuais, visando à Gestão da Qualidade: 


\section{Quadro 2: Evolução do Controle da Qualidade}

\begin{tabular}{|l|l|}
\hline ANO & Controle da qualidade \\
\hline 1900 & Controle da Qualidade pelo Operador: cada um controlava seu serviço. \\
\hline 1918 & $\begin{array}{l}\text { Controle da Qualidade pelo Supervisor: o supervisor assumia a } \\
\text { responsabilidade da qualidade referente ao trabalho da equipe. }\end{array}$ \\
\hline 1937 & $\begin{array}{l}\text { Controle da Qualidade por Inspeção: eram verificados todos os processos de } \\
\text { execução do produto. }\end{array}$ \\
\hline 1960 & $\begin{array}{l}\text { Controle Estatístico da Qualidade: quando surgiram as sete ferramentas } \\
\text { básicas da qualidade: fluxograma, Folha de verificação, Diagrama de Pareto, } \\
\text { Diagrama de causa-e-efeito, histograma, Diagrama de dispersão e carta de } \\
\text { controle (é aplicado em organizações até hoje). }\end{array}$ \\
\hline 1980 & $\begin{array}{l}\text { Gerenciamento da Qualidade: método amplo no qual foram surgindo novos } \\
\text { instrumentos além dos estatísticos (custos, confiabilidade e zero defeitos). }\end{array}$ \\
\hline
\end{tabular}

Fonte: Moretti (2003).

Hoje, toda atividade e/ou planejamento de um projeto deveria utilizar das ferramentas da qualidade para buscar indicadores de avaliação e de melhoria, com foco na satisfação do cliente.

Segundo Vergueiro (2002), as ferramentas para a Gestão da Qualidade que podem ser utilizadas pelos Serviços de Informação; destacam-se: Fluxograma, Gráfico de Pareto, Diagrama de causa-e-efeito, Folha de verificação, Histograma, Diagrama de distribuição, Tabela de controle, Gráfico de estratificação, Brainstorming, Técnica nominal de grupo, Análise de campo de forças, Checklist.

A Qualidade atua, também, no sentido de reorientar as estruturas organizacionais, de modo a proporcionar o equilíbrio entre as orientações de estratégias e as necessidades operacionais, buscando a eficiência e a eficácia nos processos da organização.

Segundo Fleury (1993), a questão da Qualidade passa pela valorização da satisfação do cliente. A autora afirma que: 
Isso, por si só, requer que o trabalhador esteja mais integrado e participativo na definição e realização do que é produzir com qualidade. As técnicas, os programas para se alcançar a qualidade e produtividade são bastante variados, porém têm pontos em comum: a estratégia organizacional voltada para a necessidade do cliente, a eliminação de perdas e a responsabilidade partilhada no cumprimento de metas (FLEURY, 1993).

Para dar sustentação à idéia de que o trabalhador deve ter o conhecimento do que é produzir com qualidade, Ishikawa já principiou seus estudos a partir da premissa de incentivar a necessidade de ampliar a educação e o treinamento para a qualidade por meio dos "Círculos de Controle de Qualidade".

Segundo Xavier (2001), "como resultado do processo de evolução das inúmeras técnicas de administração empresarial que vem ocorrendo ao longo dos anos, surge a Gestão da Qualidade, baseada em diferentes abordagens" e uma delas é a Gestão da Qualidade em Serviços de Informação. Portanto, para finalizar este item conclui-se que a Gestão pela Qualidade pode ser inserida no planejamento funcional de um Serviço de Informação. 


\subsubsection{Gestão da Qualidade em Serviços de Informação}

A questão da velocidade e do valor que a informação tem hoje para a sociedade, além de ser temática crucial e recorrente, é um componente fundamental para qualquer decisão, compreensão e competição das principais atividades produtivas das organizações. A informação, hoje, é transmitida a qualquer pessoa, a qualquer hora e em qualquer lugar, não tendo limites de espaço e tempo, facilitando a comunicação e o acompanhamento das tendências atuais de inovação (DIAS E BELUZZO, 2003). Portanto, para se conseguir esse domínio sobre qualquer tipo de informação para o seu negócio, uma organização precisa fazer uso do que é chamado de Serviço de Informação, que pode ser definido como:

a combinação de processos relacionados ao ciclo informacional dos setores científicos e produtivo, dependendo de pessoas e de uma plataforma de tecnologia, organizados para o alcance de objetivos voltados à inovação e desenvolvimento, produtividade e competitividade (DIAS E BELUZZO, 2003, p. 26).

Para completar, Lapeyere (1998) define o Serviço de Informação como: "uma atividade de respostas às necessidades de informação dos clientes e representa um valor econômico, mesmo que não corresponda à produção de um bem material".

Segundo Vergueiro (2002), pode-se verificar um "número crescente de iniciativas de aplicações dos conceitos e propostas da qualidade em serviços de informação". E, neste setor, também pode-se dizer que o objetivo primário de se começar programas de qualidade é o desejo de melhorar o processo de Gestão de Serviços ao cliente ou melhorar o controle estatístico do processo. (VALLS e VERGUEIRO, 1998).

Ainda, segundo Valls e Vergueiro (1998), a área da Informação costuma trabalhar com indicadores de qualidade. Estes métodos são tradicionalmente 
internacionais e possuem propostas para Bibliotecas Públicas e Universitárias (BROPHY, COULLING, 1966), e são denominados "padrões" ou "indicadores de desempenho". Esses indicadores devem mensurar, segundo Hernon e Altman (1996), a extensão, a efetividade e a eficiência dos programas e serviços da Biblioteca (VALLS e VERGUEIRO, 1998).

Para exemplificar, uma metodologia utilizada quanto aos indicadores em um Sistema de Informação pode-se citar a de Huidobro (1995), na qual o objetivo é salientar que "o indicador a ser estabelecido deve estar baseado em um índice de satisfação do usuário relacionado ao serviço prestado" (p.14).

Outra metodologia importante apresentada por Valls e Vergueiro (2006), é a de Boekhorst (1995) que evidencia as iniciativas da IFLA com relação ao estabelecimento de indicadores da qualidade para Bibliotecas Acadêmicas. São eles: uso geral da Biblioteca e suas facilidades; qualidade da coleção; qualidade da catalogação; disponibilidade da coleção; serviço de referência e satisfação do usuário.

Segundo Longo e Vergueiro (2003):

este interesse pela aplicação da Gestão da Qualidade em Serviços de
Informação é de fácil explicação: não são preocupações novas para os
profissionais da informação, tendo em vista ações como: estudo de uso e
de usuário, avaliação da coleção, avaliação da recuperação da
informação constituem enfoques visando avaliar tanto a qualidade dos
serviços como o cumprimento dos objetivos institucionalmente
estabelecidos pelo Serviço de Informação.

Destacando agora os estudos internacionais sobre a Gestão da Qualidade em Serviços de Informação, há os trabalhos de Guy St. Clair (1996), Peter Brophy e Kate Coulling (1996), que demonstram as iniciativas relacionadas à Gestão da Qualidade em Serviços de Informação com exemplos práticos dos benefícios gerados, em instituições, com essa implantação. 
No âmbito nacional, há também trabalhos voltados para a Gestão da Qualidade em Serviços de Informação, aplicações e relatos desde 1990.

A base teórica sobre o assunto se tornou mais consistente depois do último trabalho de Valls e Vergueiro, publicado em 2006, o qual conseguiu sistematizar os temas relacionados à Gestão da Qualidade em Serviços de Informação, e isto foi necessário, visto que os pesquisadores estudavam o tema de maneira exploratória e pioneira.

Segundo Valls (2005), tanto as Escolas e Faculdades de Ciência da Informação e Biblioteconomia e profissionais ambientados em Instituições de Ensino como alguns de Centros de Informação especializados, já vêm utilizando as técnicas e teorias da Gestão da Qualidade em seus serviços. A partir daí, a referida autora idealizou um quadro contendo todo o relato desses trabalhos com seus autores, comentários e técnicas aplicadas, enriquecendo a base teórica nacional sobre o assunto. Tal quadro compreende os primeiros trabalhos na área, como o de Areco de 1992, até um dos últimos da própria autora em 2004. Portanto, será apresentado, a seguir, um quadro baseado na aplicação dos conceitos de Gestão da Qualidade em Serviços de Informação no Brasil, apresentando o seu autor, a técnica utilizada e a forma de divulgação que foi complementado com outros estudos relevantes realizados após 2004. 
Quadro 3: Trabalhos sobre a aplicação da Gestão da Qualidade em Serviços de Informação

\begin{tabular}{|c|c|c|}
\hline AUTOR & MÉTODOS UTILIZADOS & DIVULGAÇÃO \\
\hline Areco (1992) & Método Deming & $\begin{array}{l}\text { Trabalho apresentado em } \\
\text { Evento }\end{array}$ \\
\hline $\begin{array}{lll}\text { Belluzzo } \\
(1993)\end{array}$ & Método Deming & Artigo de periódico \\
\hline Braga (1993) & $\begin{array}{l}\text { Programa de gerenciamento de } \\
\text { rotinas (diagrama de árvore) }\end{array}$ & $\begin{array}{l}\text { Trabalho apresentado em } \\
\text { Evento }\end{array}$ \\
\hline Pinto (1993) & $\begin{array}{lcr}\text { Definição } & \text { da } & \text { missão/ } \\
\text { normalização } & \text { de } & \text { processos } \\
\text { enfatizando o fluxo de clientes }\end{array}$ & Artigo de periódico \\
\hline \begin{tabular}{lll|}
$\begin{array}{l}\text { Rocha } \\
(1993)\end{array}$ & e & Gomes \\
\end{tabular} & Normalização dos processos & Artigo de periódico \\
\hline Caldeira (1994) & Aplicação do 5S & Artigo de periódico \\
\hline Vieira (1994) & Ciclo PADCT & Artigo de periódico \\
\hline Rocha Filho (1995) & Missão / Aplicação 5S & Artigo de periódico \\
\hline Belluzzo (1995) & \begin{tabular}{lrrr|} 
Capacitação & \multicolumn{2}{c|}{ de } & \multicolumn{2}{r}{ recursos } \\
humanos e & a & Gestão da \\
Qualidade & em & Bibliotecas \\
universitárias & & & \\
\end{tabular} & Tese de Doutorado \\
\hline $\begin{array}{l}\text { Silva, Almeida } \\
\text { Belluzzo (1995) }\end{array}$ & $\begin{array}{l}\text { Normalização de processos I } \\
\text { Ciclos de Qualidade }\end{array}$ & Ensaio APB \\
\hline Barbalho (1996) & $\begin{array}{llll}\begin{array}{l}\text { Ferramentas } \\
\text { Certificação }\end{array} & \text { da } & \text { ISO } & 9000 / \\
\end{array}$ & Artigo de periódico \\
\hline Barbalho (1997) & $\begin{array}{l}\text { Certificação de conformidade dos } \\
\text { SI }\end{array}$ & Artigo de periódico \\
\hline Ferreira (1997) & 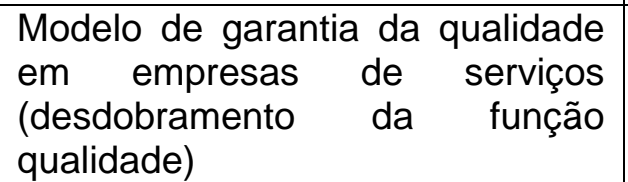 & Dissertação de Mestrado \\
\hline $\begin{array}{l}\text { Vergueiro e Belluzzo } \\
(1997)\end{array}$ & $\begin{array}{l}\text { Indicadores de Qualidade em } \\
\text { Bibliotecas Universitárias }\end{array}$ & $\begin{array}{l}\text { Trabalho apresentado em } \\
\text { Evento }\end{array}$ \\
\hline Valls (1998) & \begin{tabular}{llll|} 
Profissional da & Informação & nos \\
Sistemas da & Qualidade & em \\
Empresas & & & \\
\end{tabular} & Dissertação de Mestrado \\
\hline Vergueiro et al (1998) & 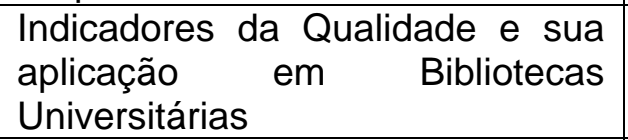 & $\begin{array}{l}\text { Trabalho apresentado em } \\
\text { Evento }\end{array}$ \\
\hline Vanti (1999) & Aplicação do 5S na prática & Artigo de periódico \\
\hline Vergueiro et al (1999) & $\begin{array}{l}\text { Gestão da Qualidade em Sl/ } \\
\text { Bibliotecas Universitárias }\end{array}$ & $\begin{array}{l}\text { Trabalho apresentado em } \\
\text { Evento }\end{array}$ \\
\hline Baptista (2000) & $\begin{array}{l}\text { Nível de satisfação do cliente em } \\
\text { Bibliotecas Universitárias }\end{array}$ & $\begin{array}{l}\text { Trabalho apresentado em } \\
\text { Evento }\end{array}$ \\
\hline \begin{tabular}{lll|} 
Linguanotto et & al \\
$(2000)$ & & \\
\end{tabular} & $\begin{array}{l}\text { Indicadores de Qualidade para o } \\
\text { serviço de referência em } \\
\text { Bibliotecas Universitárias }\end{array}$ & $\begin{array}{l}\text { Trabalho apresentado em } \\
\text { Evento }\end{array}$ \\
\hline
\end{tabular}

(Continua) 


\begin{tabular}{|c|c|c|}
\hline AUTOR & MÉTODOS UTILIZADOS & DIVULGAÇÃO \\
\hline Medeiros e tel (2000) & $\begin{array}{l}\text { Métodos gerenciais de qualidade } \\
\text { e produtividade em Bibliotecas } \\
\text { Universitárias }\end{array}$ & $\begin{array}{l}\text { Trabalho apresentado em } \\
\text { Evento }\end{array}$ \\
\hline 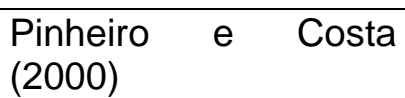 & $\begin{array}{l}\text { Método de Deming em Bibliotecas } \\
\text { Universitárias }\end{array}$ & Artigo digital \\
\hline Santos (2000) & $\begin{array}{l}\text { Projeto e análise de processos em } \\
\text { Bibliotecas }\end{array}$ & Dissertação de Mestrado \\
\hline Silva (2000a) & 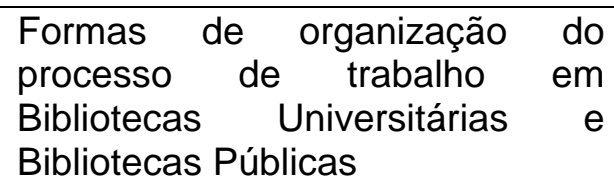 & $\begin{array}{l}\text { Trabalho apresentado em } \\
\text { Evento }\end{array}$ \\
\hline Silva (2000b) & $\begin{array}{llr}\text { Análise } & \text { dos } & \text { objetivos } \\
\text { organizacionais para melhoria da } \\
\text { qualidade em } \\
\text { Universitárias }\end{array}$ & Artigo de periódico \\
\hline Vergueiro (2000) & $\begin{array}{lccc}\text { Aplicação } & \text { da } & \text { Gestão } & \text { da } \\
\begin{array}{l}\text { Qualidade } \\
\text { Informação }\end{array} & \text { em } & \text { Serviços } & \text { de } \\
\end{array}$ & Tese de Livre-docência \\
\hline Vergueiro (2000a) & $\begin{array}{l}\text { Abordagem dos } \\
\text { prestados sob o ponto de vista } \\
\text { dos clientes em Bibliotecas } \\
\text { Universitárias }\end{array}$ & $\begin{array}{l}\text { Trabalho apresentado em } \\
\text { Evento }\end{array}$ \\
\hline Vergueiro (2000b) & $\begin{array}{l}\text { Abordagem } \\
\text { prestados sob o ponto de vista } \\
\text { dos clientes em } \\
\text { Universitárias }\end{array}$ & Artigo de periódico \\
\hline Vergueiro (2000c) & $\begin{array}{l}\text { Implantação da Gestão da } \\
\text { Qualidade em Serviços de } \\
\text { Informaçãol com foco no cliente }\end{array}$ & Artigo de periódico \\
\hline $\begin{array}{l}\text { Vergueiro e Carvalho } \\
(2000 a)\end{array}$ & $\begin{array}{l}\text { Indicadores de Qualidade em } \\
\text { Bibliotecas Universitárias }\end{array}$ & $\begin{array}{l}\text { Trabalho apresentado em } \\
\text { Evento }\end{array}$ \\
\hline $\begin{array}{l}\text { Vergueiro e Carvalho } \\
\text { (2000b) }\end{array}$ & $\begin{array}{lr}\begin{array}{l}\text { Gestão da } \\
\text { Bibliotecas } \\
\text { brasileiras }\end{array} & \begin{array}{r}\text { Qualidade em } \\
\text { Universitárias }\end{array} \\
& \end{array}$ & $\begin{array}{l}\text { Trabalho apresentado em } \\
\text { Evento }\end{array}$ \\
\hline Gomes Filho (2001) & $\begin{array}{l}\text { Método "momento da verdade" } \\
\text { em bibliotecas universitárias }\end{array}$ & Dissertação de Mestrado \\
\hline Silingovschi (2001) & $\begin{array}{lll}\text { Gestão da qualidade em } \\
\text { Bibliotecas Universitárias }\end{array}$ & Artigo digital \\
\hline $\begin{array}{c}\text { Suaiden e Araújo } \\
\text { Junior (2001) }\end{array}$ & $\begin{array}{l}\text { Benchmarking em Bibliotecas } \\
\text { Públicas }\end{array}$ & Artigo de periódico \\
\hline $\begin{array}{l}\text { Vergueiro e Carvalho } \\
\text { (2001) }\end{array}$ & $\begin{array}{l}\text { Indicadores de qualidade em } \\
\text { Bibliotecas Universitárias }\end{array}$ & Artigo de periódico \\
\hline Xavier (2001) & $\begin{array}{l}\text { Estratégias de serviços voltados } \\
\text { para a satisfação do cliente em } \\
\text { Bibliotecas Universitárias }\end{array}$ & Dissertação de Mestrado \\
\hline Amboni (2002) & $\begin{array}{l}\text { Gestão da Qualidade em serviços, } \\
\text { das Bibliotecas Universitárias } \\
\text { Federais }\end{array}$ & Tese de Doutorado \\
\hline
\end{tabular}




\begin{tabular}{|c|c|c|}
\hline \multicolumn{3}{|l|}{ (continuação) } \\
\hline AUTOR & MÉTODOS UTILIZADOS & DIVULGAÇÃO \\
\hline Ferreira (2002a) & Aplicação 5S & $\begin{array}{l}\text { Trabalho apresentado em } \\
\text { Evento }\end{array}$ \\
\hline Fonseca et al (2002) & $\begin{array}{l}\text { Indicadores de Qualidade em } \\
\text { Bibliotecas Universitárias }\end{array}$ & $\begin{array}{l}\text { Trabalho apresentado em } \\
\text { Evento }\end{array}$ \\
\hline Gomes Filho (2002) & $\begin{array}{llr}\text { Aplicação } & \text { de } & \text { técnicas } \\
\text { administrativas } & \text { em } & \text { Bibliotecas } \\
\text { Universitárias } & & \\
\end{array}$ & $\begin{array}{l}\text { Trabalho apresentado em } \\
\text { Evento }\end{array}$ \\
\hline Martins et al (2002) & $\begin{array}{l}\text { Identificação dos requisitos do } \\
\text { cliente baseado na proposta de } \\
\text { Garvin em } \\
\text { Universitárias }\end{array}$ & $\begin{array}{l}\text { Trabalho apresentado em } \\
\text { Evento }\end{array}$ \\
\hline Ramos (2002) & $\begin{array}{l}\text { Padrões para } \begin{array}{l}\text { avaliação da } \\
\text { qualidade } \\
\text { Universitárias }\end{array} \\
\text { em }\end{array}$ & $\begin{array}{l}\text { Trabalho apresentado em } \\
\text { Evento }\end{array}$ \\
\hline Sampaio et al (2002a) & $\begin{array}{lll}\text { Implantação do PAQ em } & \text { em } \\
\text { bibliotecas universitárias } & \\
\end{array}$ & $\begin{array}{l}\text { Trabalho apresentado em } \\
\text { Evento }\end{array}$ \\
\hline Sampaio et al (2002b) & $\begin{array}{l}\begin{array}{l}\text { Identificação dos } \\
\text { cliente requisitos do } \\
\text { Universitárias }\end{array} \\
\end{array}$ & $\begin{array}{l}\text { Trabalho apresentado em } \\
\text { Evento }\end{array}$ \\
\hline Silva (2002) & $\begin{array}{l}\text { Gestão da Qualidade Total em } \\
\text { Serviços de Informação }\end{array}$ & $\begin{array}{l}\text { Trabalho apresentado em } \\
\text { Evento }\end{array}$ \\
\hline Vergueiro (2002) & $\begin{array}{l}\text { Gestão da Qualidade em Serviços } \\
\text { de Informação }\end{array}$ & Livro \\
\hline $\begin{array}{l}\text { Vergueiro e Carvalho } \\
(2002 \mathrm{a})\end{array}$ & $\begin{array}{l}\text { Gestão da Qualidade } \\
\begin{array}{l}\text { Bibliotecas Universitárias } \\
\text { enfoque na certificação }\end{array} \\
\text { com }\end{array}$ & $\begin{array}{l}\text { Trabalho apresentado em } \\
\text { Evento }\end{array}$ \\
\hline $\begin{array}{l}\text { Vergueiro e Carvalho } \\
(2002 \mathrm{~b})\end{array}$ & $\begin{array}{llr}\text { Indicadores } & \text { de } & \text { qualidade e } \\
\text { marketing } & \text { em } & \text { Bibliotecas } \\
\text { Universitárias } & & \\
\end{array}$ & Artigo de periódico \\
\hline Barbêdo et al (2003) & $\begin{array}{l}\text { Método desdobramento da função } \\
\text { qualidade (QFD) em Bibliotecas } \\
\text { Universitárias }\end{array}$ & $\begin{array}{l}\text { Trabalho apresentado em } \\
\text { Evento }\end{array}$ \\
\hline $\begin{array}{lll}\begin{array}{l}\text { Barbêdo } \\
(2003 a)\end{array} & \text { e Turrioni } \\
\end{array}$ & $\begin{array}{l}\text { Modelos administrativos e ISO } \\
9000 \text { em Bibliotecas Universitárias }\end{array}$ & $\begin{array}{l}\text { Trabalho apresentado em } \\
\text { Evento }\end{array}$ \\
\hline $\begin{array}{l}\text { Barbêdo e } \text { Turrioni } \\
(2003 \mathrm{~b})\end{array}$ & $\begin{array}{l}\text { Estágio evolutivo e dimensões da } \\
\text { qualidade (Garvin) em Bibliotecas } \\
\text { Universitárias }\end{array}$ & Artigo de periódico \\
\hline $\begin{array}{lll}\text { Longo } & \text { e } & \text { Vergueiro } \\
(2003) & & \end{array}$ & $\begin{array}{l}\text { Gestão da Qualidade Total em } \\
\text { Serviços da Informação do setor } \\
\text { público }\end{array}$ & Artigo de periódico \\
\hline Santos et al (2003) & Técnica de gestão de processos & Artigo de periódico \\
\hline $\begin{array}{l}\text { Vergueiro e Carvalho } \\
(2003)\end{array}$ & $\begin{array}{l}\text { Gestão da Qualidade em } \\
\text { Bibliotecas brasileiras }\end{array}$ & Artigo de periódico \\
\hline Amboni (2004) & $\begin{array}{l}\text { Gestão da Qualidade em serviços, } \\
\text { das Bibliotecas Universitárias } \\
\text { Federais }\end{array}$ & $\begin{array}{l}\text { Trabalho apresentado em } \\
\text { evento }\end{array}$ \\
\hline
\end{tabular}


(continuação)

\begin{tabular}{|c|c|c|}
\hline AUTOR & MÉTODOS UTILIZADOS & DIVULGAÇÃO \\
\hline Andrade (2004) & $\begin{array}{l}\text { Gestão da qualidade, indicadores } \\
\text { de padrões em Bibliotecas } \\
\text { Universitárias }\end{array}$ & Dissertação de Mestrado \\
\hline Barbêdo (2004) & $\begin{array}{l}\text { Sistema de Gestão da Qualidade } \\
\text { em Serviços aplicado em } \\
\text { Bibliotecas Universitárias }\end{array}$ & Dissertação de Mestrado \\
\hline $\begin{array}{lrl}\text { Castro } & \text { Filho } & \text { e } \\
\text { Vergueiro (2004) }\end{array}$ & $\begin{array}{l}\text { Gestão de pessoas sob a ótica } \\
\text { das teorias da Qualidade }\end{array}$ & $\begin{array}{l}\text { Trabalho apresentado em } \\
\text { evento }\end{array}$ \\
\hline Fonseca et al (2004) & $\begin{array}{l}\text { Indicadores da Qualidade para a } \\
\text { gestão de } \\
\text { Universitárias }\end{array}$ & $\begin{array}{l}\text { Trabalho apresentado em } \\
\text { evento }\end{array}$ \\
\hline $\begin{array}{ll}\text { Gomes } & \text { Filho } \\
\text { Honesko (2004) }\end{array}$ & $\begin{array}{l}\text { A Qualidade e empreendedorismo } \\
\text { em Unidades de Informação }\end{array}$ & Livro \\
\hline Igami et al (2004) & $\begin{array}{l}\text { Uso do SERVQUAL em Unidades } \\
\text { de Informação }\end{array}$ & $\begin{array}{l}\text { Trabalho apresentado em } \\
\text { evento }\end{array}$ \\
\hline Martins e Lotti (2004) & $\begin{array}{l}\text { Implantação da Norma ISO } \\
\text { 9001:2000 em Bibliotecas }\end{array}$ & $\begin{array}{l}\text { Trabalho apresentado em } \\
\text { evento }\end{array}$ \\
\hline $\begin{array}{lcc}\text { Moretti } & \text { e } & \text { Pereira } \\
\text { Junior }(2004) & \end{array}$ & $\begin{array}{llrr}\text { Auditorias em } & \begin{array}{l}\text { Sistemas } \\
\text { Gestão da } \\
\text { Qualidade } \\
\text { Bibliotecas }\end{array} & & \text { em } \\
\end{array}$ & $\begin{array}{l}\text { Trabalho apresentado em } \\
\text { evento }\end{array}$ \\
\hline Nunes e Silva (2004) &  & $\begin{array}{l}\text { Trabalho apresentado em } \\
\text { evento }\end{array}$ \\
\hline Rebello (2004) & $\begin{array}{l}\text { Pesquisa de satisfação de usuário } \\
\text { de Bibliotecas Universitárias } \\
\text { baseada no SERVQUAL }\end{array}$ & Artigo de periódico \\
\hline $\begin{array}{l}\text { Reis e Blattmann } \\
(2004)\end{array}$ & $\begin{array}{l}\text { Gestão de processos em Serviços } \\
\text { de Informação }\end{array}$ & Artigo de periódico \\
\hline Saad et al (2004) & $\begin{array}{l}\text { Prêmio paulista de Qualidade de } \\
\text { Gestão }\end{array}$ & $\begin{array}{l}\text { Trabalho apresentado em } \\
\text { evento }\end{array}$ \\
\hline Salasario (2004) & $\begin{array}{l}\text { Avaliação da Qualidade através } \\
\text { da ótica dos usuários/clientes }\end{array}$ & $\begin{array}{l}\text { Trabalho apresentado em } \\
\text { evento }\end{array}$ \\
\hline Sampaio (2004a) & $\begin{array}{l}\text { Curso a distância sobre Qualidade } \\
\text { em Serviços de Informação }\end{array}$ & $\begin{array}{l}\text { Trabalho apresentado em } \\
\text { evento }\end{array}$ \\
\hline Sampaio (2004b) & $\begin{array}{llll}\text { Programa de avaliação } & \text { da } \\
\text { Qualidade }\end{array}$ & Artigo de periódico \\
\hline Sampaio et al (2004) & $\begin{array}{l}\text { Avaliação da Qualidade em } \\
\text { Bibliotecas Universitárias }\end{array}$ & Artigo de periódico \\
\hline Valls (2004) & $\begin{array}{l}\text { ISO } 9001 \text { e sua aplicação nos } \\
\text { Serviços de informação }\end{array}$ & Artigo de periódico \\
\hline $\begin{array}{l}\text { Bonetti e Machado } \\
(2005)\end{array}$ & $\begin{array}{l}\text { Gestão da Qualidade aplicada em } \\
\text { Bibliotecas Universitárias da } \\
\text { região Sul }\end{array}$ & $\begin{array}{l}\text { Trabalho apresentado em } \\
\text { evento }\end{array}$ \\
\hline
\end{tabular}




\begin{tabular}{|c|c|c|}
\hline \multicolumn{3}{|l|}{ (continuação) } \\
\hline AUTOR & MÉTODOS UTILIZADOS & DIVULGAÇÃO \\
\hline Dalpizzo et al (2005) & $\begin{array}{l}\text { Psicologia organizacional e a } \\
\text { Gestão da Qualidade }\end{array}$ & $\begin{array}{l}\text { Trabalho apresentado em } \\
\text { evento }\end{array}$ \\
\hline Valls (2005) & $\begin{array}{l}\text { ISO } 9000 \text { e sua aplicação nos } \\
\text { Serviços de Informação }\end{array}$ & $\begin{array}{l}\text { Trabalho apresentado em } \\
\text { evento }\end{array}$ \\
\hline Valls (2005) & $\begin{array}{l}\text { Gestão da Qualidade em Serviços } \\
\text { de Informação no Brasil baseado } \\
\text { na ISO } 9001\end{array}$ & Tese de Doutorado \\
\hline Vicentini (2005) & $\begin{array}{l}\text { Indicadores de Qualidade em } \\
\text { Bibliotecas Digitais }\end{array}$ & $\begin{array}{l}\text { Dissertação de Mestrado } \\
\text { Profissional }\end{array}$ \\
\hline Martins (2004) & $\begin{array}{l}\text { Indicadores de Qualidade em } \\
\text { sistemas de Bibliotecas }\end{array}$ & $\begin{array}{l}\text { Dissertação de Mestrado } \\
\text { Profissional }\end{array}$ \\
\hline Cardoso e Luz (2005) & $\begin{array}{l}\text { Gestão da Qualidade aplicado em } \\
\text { Serviços de informação de } \\
\text { Arquivos }\end{array}$ & Artigo de periódico \\
\hline Rozados (2005) & $\begin{array}{l}\text { Indicadores como ferramenta de } \\
\text { avaliação }\end{array}$ & $\begin{array}{l}\text { Trabalho apresentado em } \\
\text { evento }\end{array}$ \\
\hline Rozados (2005a) & $\begin{array}{l}\text { Uso de indicadores na Gestão de } \\
\text { recursos de informação }\end{array}$ & Artigo de periódico \\
\hline Zanella (2005) & $\begin{array}{l}\text { Qualidade de Serviços em } \\
\text { Biblioteca Universitária }\end{array}$ & $\begin{array}{l}\text { Trabalho apresentado em } \\
\text { evento }\end{array}$ \\
\hline Walter (2005) & $\begin{array}{lllll}\begin{array}{l}\text { Aplicação } \\
\text { Biblioteca }\end{array} & \text { da } & \text { ISO } & 9000 & \text { em } \\
\end{array}$ & Artigo de periódico \\
\hline $\begin{array}{lll}\text { Valls } & \text { e } & \text { Vergueiro } \\
(2006) & & \end{array}$ & $\begin{array}{l}\text { Gestão da qualidade em Serviços } \\
\text { de Informação com base na ISO } \\
9000\end{array}$ & de periódico \\
\hline $\begin{array}{l}\text { Valls e } \\
(2006 a)\end{array}$ & $\begin{array}{l}\text { Nova revisão de literatura sobre a } \\
\text { Gestão da Qualidade em Serviços } \\
\text { de Informação }\end{array}$ & le periódico \\
\hline Ferreira (2006) & $\begin{array}{l}\text { Profissional da Informação e a } \\
\text { Gestão da Qualidade em Serviços } \\
\text { de Informação / capacitação e } \\
\text { educação continuada }\end{array}$ & $\begin{array}{l}\text { Trabalho apresentado em } \\
\text { evento }\end{array}$ \\
\hline $\begin{array}{l}\text { Guimarães } \\
\text { (2006) }\end{array}$ & $\begin{array}{l}\text { Indicadores de desempenho de } \\
\text { Bibliotecas no campo da saúde }\end{array}$ & Artigo de periódico \\
\hline $\begin{array}{l}\text { Barbêdo e Vergueiro } \\
(2006)\end{array}$ & $\begin{array}{l}\text { Qualidade em Bibliotecas } \\
\text { Universitárias Públicas }\end{array}$ & $\begin{array}{l}\text { Trabalho apresentado em } \\
\text { evento }\end{array}$ \\
\hline
\end{tabular}

Fontes: Adaptado dos trabalhos de Valls e Vergueiro (1998), Valls (2005) e Valls e Vergueiro (2006). 
Da análise realizada por meio do quadro apresentado, pode-se concluir que a literatura nacional na área de Gestão da Qualidade em Serviços de Informação não é extensa, mas tem evoluído e interessado a alguns profissionais que buscam melhorias em seus ambientes de trabalho. Constata-se que o ambiente mais citado, como ambientes de aplicação ou estudo de caso são as Bibliotecas Universitárias e pouco foi encontrado em outros ambientes, como o empresarial, por exemplo. Constata-se também que a maioria das divulgações foi feita por meio de artigos de periódicos, talvez seja esse o meio mais rápido de divulgar resultados práticos; seguido pelos trabalhos apresentados em eventos; e pesquisas acadêmicas como temática em dissertações de Mestrado e tese de Doutorado.

Portanto, uma das importâncias da divulgação desses estudos é compartilhar com os pares - profissionais da informação - as teorias e técnicas de Gestão da Qualidade que foram eficientes, ou não, cada um no seu contexto. Isso não se levando em conta que existem ainda muitas práticas e pesquisas feitas sobre o tema, mas que não são divulgadas.

Continuando a revisão de literatura, parte-se agora para um dos temas importantes a serem discutidos nesta pesquisa: o Profissional da Informação, Bibliotecário. No próximo item será relatada uma revisão de estudos sobre a evolução do mercado de trabalho, da formação e do perfil desse profissional, para que, mais brevemente, se possa relacioná-los aos princípios da Gestão da Qualidade. 


\subsection{O Mercado de trabalho do Profissional da Informação}

Este tópico tem por finalidade relatar as principais pesquisas sobre 0 mercado de trabalho dos Profissionais da Informação, permitindo com isso, analisar as mudanças por que passam os ambientes de trabalho desse profissional.

Estudos que analisam o mercado de trabalho encontram-se em diferentes parâmetros dentro da Ciência da Informação, por exemplo, pode-se realizar a análise salientando aspectos específicos das profissões da Informação, tais como: "levantamento das funções exercidas, os novos espaços ocupados, a interação com outras profissões, estabelecimento de paralelos entre as atividades tradicionais e as novas, também estudos sobre os cursos e escolas que formam esses profissionais" (CUNHA, 2000b, p.7).

O embasamento para se estabelecer a relação das pesquisas existentes foi a literatura de Cunha (2000b, 2000c, 2000d), com revisão especialmente elaborada sobre o mercado de trabalho do Profissional da Informação e que contemplam os principais estudos brasileiros e alguns internacionais, publicados entre 1969 e 1998.

Para elucidar tal revisão, a seguir haverá a apresentação de dois quadros: um com os principais estudos internacionais e outro com os principais estudos brasileiros. E ainda para complementar haverá também a exposição de alguns dos principais estudos e pesquisas brasileiros sobre o perfil e mercado de trabalho do Profissional da Informação, que foram publicados de 1998 até 2006. 
Quadro 4: Principais estudos internacionais sobre o mercado de trabalho do Profissional da Informação

\begin{tabular}{|c|c|c|}
\hline ANO & AUTOR/PAÍS & DESCRIÇÃO \\
\hline 1969 & $\begin{array}{l}\text { Wasserrman e Bundy - } \\
\text { Estados Unidos }\end{array}$ & $\begin{array}{l}\text { Primeiro estudo sobre a mudança de perfil do } \\
\text { Profissional da Informação }\end{array}$ \\
\hline 1975 & $\begin{array}{lll}\text { Harmon } & - & \text { Estados } \\
\text { Unidos } & & \end{array}$ & Desenvolvimento da idéia de mercado emergente \\
\hline 1978 & $\begin{array}{l}\text { Neelameghn } \\
\text { Internacional }\end{array}$ & $\begin{array}{l}\text { Princípios para a elaboração de políticas relativas à } \\
\text { formação do pessoal de bibliotecas }\end{array}$ \\
\hline 1981 & $\begin{array}{l}\text { Debons et al - Estados } \\
\text { Unidos }\end{array}$ & $\begin{array}{l}\text { Pesquisa sobre o mercado de trabalho da } \\
\text { Informação }\end{array}$ \\
\hline 1983 & Cronin - Inglaterra & $\begin{array}{l}\text { Categorização do mercado emergente da } \\
\text { Informação }\end{array}$ \\
\hline 1984 & $\begin{array}{l}\text { Chen, Raskin e Tebbets } \\
\text { - Estados Unidos }\end{array}$ & $\begin{array}{l}\text { Categorização do mercado emergente } \\
\text { Informação }\end{array}$ \\
\hline 1984 & Soenem - França & $\begin{array}{l}\text { Primeiro estudo francês sobre o mercado de } \\
\text { trabalho dos documentalistas }\end{array}$ \\
\hline 1986 & $\begin{array}{l}\text { Griffiths e King - Estados } \\
\text { Unidos }\end{array}$ & Caracterização do ambiente de Informação \\
\hline 1987 & Moore - Inglaterra & $\begin{array}{l}\text { Categorização do mercado emergente da } \\
\text { Informação }\end{array}$ \\
\hline 1991 & Mostafa - Inglaterra & $\begin{array}{l}\text { Reflexão entre o mercado tradicional e o mercado } \\
\text { emergente da Informação }\end{array}$ \\
\hline 1992 & FID - Internacional & Criação do Grupo Especial MIP \\
\hline 1996 & SLA - Internacional & $\begin{array}{l}\text { Mercado, competências e perfil do bibliotecário do } \\
\text { século } 21\end{array}$ \\
\hline 1997 & FID - Internacional & $\begin{array}{l}\text { Enquête sobre o moderno profissional da } \\
\text { informação }\end{array}$ \\
\hline 1998 & $\begin{array}{l}\text { ADBS (Association dês } \\
\text { professionnels } \\
\text { ínformation et de la } \\
\text { documentacion }\end{array}$ & $\begin{array}{l}\text { Estudo francês da associação de profissionais } \\
\text { sobre o mercado emergente }\end{array}$ \\
\hline 2003 & SLA - Internacional & $\begin{array}{l}\text { Revisão: Mercado, competências e perfil do } \\
\text { bibliotecário do século } 21\end{array}$ \\
\hline
\end{tabular}

Fonte: Adaptado de Cunha, 2000b, p.9. 
O marco inicial dos estudos sobre o mercado de trabalho dos Profissionais da Informação da área da Ciência da Informação é 1969, com um estudo dirigido por Wasseman \& Bundy, nos Estados Unidos. Estes autores deram início a estudos que refletiram sobre a mudança do mercado de trabalho do Profissional da Informação.

Outros marcos importantes são os estudos internacionais realizados pela FID (Federação Internacional de Informação de Documentação) de 1997, pela ADBS (Association des Professionnels de l'Information et de la Documentation) de 1998 e pela SLA (Special Libraries Association) de 1996 e 2003. Nesses trabalhos foram desenvolvidos estudos fundamentais na definição de critérios para a identificação dos mercados emergentes e o novo perfil do Profissional da Informação.

Em relação aos trabalhos nacionais, segue o quadro:

Quadro 5: Principais estudos brasileiros sobre o mercado de trabalho do Profissional da Informação

\begin{tabular}{|l|l|l|}
\hline ANO & AUTOR & DESCRIÇÃO \\
\hline 1976 & Polke, Araújo e Cesarino & $\begin{array}{l}\text { Análise do mercado do bibliotecário em } \\
\text { Belo Horizonte }\end{array}$ \\
\hline 1984 & Robredo et al & Perfil do Profissional da Informação \\
\hline 1986 & Maia & $\begin{array}{l}\text { Serviços não convencionais desenvolvidos } \\
\text { por Profissionais da Informação }\end{array}$ \\
\hline 1987 & $\begin{array}{l}\text { Botelho Corte; } \\
\text { Figueiredo }\end{array}$ & $\begin{array}{l}\text { Considerações sobre o mercado de trabalho } \\
\text { do bibliotecário na região Centro-Oeste; } \\
\text { Capacitação profissional }\end{array}$ \\
\hline 1990 & $\begin{array}{l}\text { Tarapanoff; } \\
\text { Muller; Robredo Miranda; }\end{array}$ & $\begin{array}{l}\text { Profissional e as novas tendências; } \\
\text { Capacitação profissional; Perfil e formação; } \\
\text { Considerações sobre o mercado de trabalho } \\
\text { do bibliotecário em bibliotecas } \\
\text { especializadas do Distrito Federal }\end{array}$ \\
\hline
\end{tabular}




\begin{tabular}{|c|c|c|}
\hline \multicolumn{3}{|c|}{ (Continuação) } \\
\hline ANO & AUTOR & DESCRIÇÃO \\
\hline 1991 & Ciancioni & $\begin{array}{l}\text { Estudo sobre a mudança do perfil do } \\
\text { Profissional da Informação }\end{array}$ \\
\hline 1992 & Lopes, Poblacion e Viá & $\begin{array}{l}\text { Estudo sobre o mercado de trabalho dos } \\
\text { Profissionais da Informação e os egressos } \\
\text { da Escola de Comunicação e Artes da USP }\end{array}$ \\
\hline 1993 & Tálamo & $\begin{array}{l}\text { Estudo sobre os cursos de Graduação e } \\
\text { mercado de trabalho do bibliotecário }\end{array}$ \\
\hline 1994 & Montalli & $\begin{array}{l}\text { Estudo do profissional de Bibliotecas } \\
\text { Universitárias frente às novas tecnologias }\end{array}$ \\
\hline 1995 & $\begin{array}{lll}\text { Marengo; } & \text { Mostafa } \quad \text { e } \\
\text { Pacheco. } & & \end{array}$ & $\begin{array}{l}\text { Análise do mercado de trabalho do } \\
\text { bibliotecário na grande São Paulo; O } \\
\text { mercado emergente e o Profissional da } \\
\text { Informação }\end{array}$ \\
\hline 1996 & Tarapanoff; Gomes et al & $\begin{array}{l}\text { Estudo sobre perfil profissional; Perfil } \\
\text { profissional e as novas tecnologias }\end{array}$ \\
\hline 1997 & Tarapanoff ; Guimarães & $\begin{array}{l}\text { Estudo sobre educação continuada; Estudo } \\
\text { sobre o Moderno Profissional da Informação }\end{array}$ \\
\hline 2000 & Cunha; Valentim & $\begin{array}{l}\text { Estudo e revisão de literatura sobre o } \\
\text { Profissional da Informação; Coletânea de } \\
\text { textos referentes a formação e perfil } \\
\text { profissional no novo milênio }\end{array}$ \\
\hline 2001 & Hommerding & $\begin{array}{l}\text { Estudo sobre os novos espaços de atuação } \\
\text { do Profissional da Informação }\end{array}$ \\
\hline 2002 & $\begin{array}{l}\text { Ferreira; Neves; } \\
\text { Tarapanoff, Suaiden e } \\
\text { Oliveira; Rodrigues }\end{array}$ & $\begin{array}{l}\text { Pesquisa sobre perfil e mercado do } \\
\text { Profissional da Informação; perfil e } \\
\text { habilidades do Profissional da Informação; } \\
\text { as funções do Profissional da Informação; } \\
\text { Discussão sobre a formação do profissional }\end{array}$ \\
\hline 2005 & Souto & $\begin{array}{l}\text { Coletânea de textos sobre pesquisas } \\
\text { referentes às mudanças relacionadas ao } \\
\text { Profissional da Informação }\end{array}$ \\
\hline 2006 & $\begin{array}{l}\text { Araújo e Rocha, Martins, } \\
\text { Silva, Lima et al }\end{array}$ & $\begin{array}{l}\text { Pesquisas e estudos apresentados no } \\
\text { Seminário Nacional de Bibliotecas } \\
\text { Universitárias, relacionados ao novo perfil } \\
\text { do Profissional da Informação. }\end{array}$ \\
\hline
\end{tabular}

FONTE: Adaptado de Cunha (2000a). 
Dentre os estudos brasileiros e internacionais, identificou-se, a partir do estudo de Cunha (2000b, p.1), a existência do mercado de trabalho tradicional e emergente do Profissional da Informação e este foi analisado por meio de três abordagens relacionadas: funcional (mercado tradicional), institucional e educativa (mercado emergente). Assim sendo, comentar-se-á a seguir estes estudos (quadros 4 e 5) de acordo com as respectivas abordagens:

\section{a) Abordagem funcional}

A abordagem funcional abrange o mercado e as funções tradicionais desse profissional, em que se podem caracterizar estudos que vão desde análises das atividades de Informação, da comparação com outras categorias profissionais, até os que trazem inventários das competências das profissões da Informação (FERREIRA, 2002b).

Nessa abordagem existem duas formas de se analisar o mercado segundo Cunha (2000b): um primeiro olhar parte do interior da profissão para seu exterior, de forma a identificar as possibilidades de emprego desses profissionais; um segundo, analisa o mercado a partir do exterior, do ponto de vista das empresas onde os profissionais trabalham, analisando as funções da Informação em todo tipo de atividade.

Muitos estudos brasileiros de mercado já realizados caracterizaram-se por envolver aspectos teóricos (TARAPANOFF, 1996; MONTALLI, 1994; CIACIOLI, 1991) e entrevistas como o de Maia (1986), que foi um dos primeiros estudos a analisar as funções da Informação realizadas fora da Biblioteca; seguido pelo de Mostafa e Pacheco (1995). O estudo de Tarapanoff (1989) verificou que o mercado de trabalho do Profissional da Informação solicita profissionais com perfis cada vez mais diversificados. Um estudo semelhante foi o de Ferreira (2002b), que analisou o perfil e o mercado de trabalho dos profissionais demandados pelas empresas de recrutamento. 
Por outro lado, alguns estudos envolveram análises a partir das ofertas de emprego divulgadas em jornais, como o de Marengo (1995) e o de Neves (2002), que foram originais em detectar que os empregadores procuram profissionais com características e competências específicas - difíceis de encontrar - concluindo que a formação deve adaptar-se a essa diversificação, pois é a forma de tal profissional ser reconhecido no mercado.

\section{b) Abordagem institucional}

A abordagem institucional caracteriza-se por estudos que envolvem a unidade de Informação onde o profissional está inserido, ou seja, o tipo de profissional é definido em função do espaço de trabalho onde atua. (CUNHA, 2000c). São poucos estudos com essa abordagem, valendo ressaltar o trabalho internacional da FID - Federação Internacional de Informação de Documentação (1992 a 1997) sobre o moderno Profissional da Informação e sua versão brasileira realizada por Tarapanoff (1997).

A partir da década de 90, foram realizados vários estudos - nacionais e internacionais - sobre o perfil do Profissional da Informação e um deles teve o objetivo de identificar os setores onde eram necessárias pesquisas de forma a assegurar que o papel e as funções desses profissionais fossem compreendidos e pudessem encorajar o seu crescimento (FID, 1997).

Nacionalmente, a pesquisa de Tarapanoff (1997) teve o mesmo objetivo deste estudo da FID, evidenciando também a inadequação da formação dos profissionais no Brasil, salientando que o perfil desse profissional ainda é muito conservador, devido à rigidez da lei que regulamenta o exercício da profissão (FERREIRA, 2002b). 
O termo "moderno profissional da informação (MIP)" foi criado pela FID, em 1991, e vale ressaltar, também, outros estudos nacionais, como os de Guimarães (1997), e internacionais, como os de Mason (1990), relacionados ao moderno Profissional da Informação (MIP) e considerados importantes referenciais no assunto.

Ainda relacionado a esta abordagem, salienta-se que o estudo de Cronin (1983) foi o marco sobre pesquisas relacionadas ao mercado emergente e foi referencial para as pesquisas brasileiras de Mostafa e Pacheco (1995); Marengo (1995); Gomes et al (1996); Hommerding (2001); Ferreira (2002b) e Neves (2002).

\section{c) Abordagem educativa}

A abordagem educativa se "fundamenta na pesquisa de uma melhor adequação do conteúdo dos cursos de Biblioteconomia, Documentação e Ciência da Informação às novas atividades dos profissionais da informação" (CUNHA, 2000d, p. 5).

Dentre os principais estudos relacionados a esta abordagem, os internacionais são: Neelameghan (1978), Cronin (1982) e Soenen (1987 e 1990). E os nacionais: Polke, Araújo e Cesarino (1976), Robredo (1984 e 1989), Botelho e Corte (1987), Figueiredo (1987, 1990 e 1993), Miranda (1989), Muller (1989), Vieira et al (1990), Lopes, Poblacion e Via (1992), Vieira (1996), Gomes, Mello e Santos (1996) e Guimarães (1997)

No Brasil, boa parte dos estudos adota a abordagem educativa, pois são modos de avaliar a formação dada a esses profissionais advindos das escolas que oferecem formação na área da Ciência da Informação. (MULLER, 1985, MULLER, 1989, BERAQUET e VALENTIM, 2000, SANTOS, 2000, RODRIGUES, 2002). 
A outra parte desses estudos brasileiros, enfoca o mercado tradicional das Bibliotecas e Centros de Documentação e poucos autores preocupam-se com os novos espaços de trabalho, com exceção do trabalho de Vieira et al. (1990), pois esta autora publicou os resultados práticos da pesquisa e as modificações que afetaram os conteúdos dos cursos de formação deste profissional. Pode-se citar outros importantes estudos, os quais também trabalharam sobre esta abordagem a partir do ano de 2000, como o de Ferreira (2002b) e o de Neves (2002).

Pode-se identificar e constatar com Cunha (2000d), que a maioria dos estudos de mercado contentam-se em analisar a opinião dos Profissionais da Informação, pois há alguns estudos como o de Lopes, Población e Viá (1992), Vieira et al (1990) e Ferreira (2002b) que levam em conta a opinião dos empregadores. Considera-se importante este outro enfoque, pois permite fazer uma análise das competências e formação requerida por organizações as quais necessitam do trabalho deste profissional.

Estudos enfocando o mercado de trabalho do Profissional da Informação são abundantes, mas esta é uma temática ainda carente de estudos freqüentes e concorda-se, segundo constatação de Cunha (2000d), que estes estudos, principalmente os brasileiros, não são contínuos. Da mesma forma, é de grande importância a divulgação dos resultados destes estudos.

Finalizando este item, pôde-se constatar a identificação de um grupo de pesquisa consolidado sobre o perfil do Profissional da Informação e o seu mercado de trabalho (Grupo de pesquisa mercado de trabalho do Profissional da Informação da Universidade de Brasília, formado em 2000) e, além disso, a discussão em torno desta temática também está cada vez mais freqüente em eventos da área (MARTINS, 2006; SILVA, 2006; ARAUJO e ROCHA, 2006; LIMA et al, 2006). 


\subsubsection{As novas funções e o perfil dos Profissionais da Informação}

Segundo Mostafa (1991 apud Ferreira, 2002), as mudanças do mercado emergente repercutem no mercado tradicional e ambos não devem ser tratados como "entidades separadas". Desta forma, tendo em vista que as profissões da Informação têm-se caracterizado pela variedade e multiplicidade de suas funções, parece plausível que um mesmo profissional realize, ao mesmo tempo, as atividades consideradas tradicionais e as emergentes.

O referencial de estudo sobre o mercado emergente são os trabalhos internacionais de Cronin (1983), Stiffler e Day (1993), e nacional de Valentim (2000). Nestes estudos, viu-se a evolução do mercado impulsionada pelas novas tecnologias que transformam a natureza e a forma do trabalho informacional, concluindo que é no mercado emergente que se desenvolvem funções como a de gestor de recursos informacionais, gerente de sistemas de Informação, trabalhador do Conhecimento, gestor do conhecimento, ou seja, surgem os perfis emergentes da profissão. Ainda completando essa idéia, Cunha (2000d) relacionou as principais funções do mercado emergente, que não são novas, mas que enfrentaram e continuam enfrentando mudanças nestes últimos anos:

- Gestor da Informação e coordenador de fluxos de Informação: desempenham as atividades de coordenação e de síntese das atividades funcionais da instituição, cuja finalidade é resolver as necessidades de Informação;

- Auditor e consultor de Informação: faz uma interação personalizada com o usuário para a resolução de um problema, avaliação e aplicação da Informação;

- Analista da Informação: analisa o valor da Informação para ajuda na tomada de decisões; 
- Conceptor de sistemas de Informação: desenvolve atividades relativas a soluções relacionadas à interface entre usuários, comunicação e aconselhamento na área de informática;

- Educador: realiza atividades que envolvem a formação do usuário, relacionadas à Internet, recursos da rede, organizar informações, acesso às bases de dados.

Por fim, observou-se que os Profissionais da Informação apresentam funções híbridas que podem vir a requerer características de bibliotecário, documentalista, gestor, profissional de informática ou especialista de comunicação, ou seja, não há um perfil único para esta função. O que se pode dizer é que existem perfis específicos associados a um ou a vários papéis.

\subsubsection{A formação e as competências do Profissional da Informação do século XXI}

Tomando por base os Serviços de Informação, estes possuem como característica principal a prestação de serviços à comunidade e sociedade em geral, de forma tangível ou intangível. E, assim, todo o trabalho de processar, transmitir e disseminar a informação depende das pessoas, de seus talentos e de suas competências (DIAS e BELLUZZO, 2003). Portanto, não existe organização e não existe sucesso sem pessoas, as quais são consideradas elemento fundamental capaz de acumular e gerir conhecimento.

Diante desses aspectos, surge a preocupação com relação à formação do Profissional da Informação e o desenvolvimento de suas características de liderança e de ser gestor de Serviços de Informação baseados no modelo participativo e no trabalho em equipe. Reforçando esse papel de líder, segundo Pinheiro e Macieir (1998), "o líder lidera por se destacar e influenciar um grupo", ou seja, um indivíduo influencia outros a se comprometerem e buscarem objetivos 
comuns, ações estas que influenciam também o papel do Profissional da Informação.

Com base neste conceito, vale lembrar que o líder de um Serviço de Informação deverá interagir com uma equipe multidisciplinar. Portanto, em que consiste a formação desse profissional?

Segundo Dias e Belluzzo (2003), essa formação consiste no desenvolvimento de competências múltiplas sendo estas englobadas por conceitos de competência - tais como: processos de trabalho; técnicas; organização; fluxos de trabalho e cadeia produtiva; serviços; analise do impacto sobre os clientes e as competências sociais e análise comportamental.

Como questão curiosa e preocupante, Dias e Beluzzo (2003) afirmam que, na prática, são poucas as organizações que possuem e fazem uso de Serviços de Informação. E justificam, por meio de Davenport (1998), que o grande obstáculo para esse uso efetivo é a "falta de formação dos empresários" para esse fim, qual seja o tratamento da informação (aquisição, organização, análise, síntese, armazenamento, recuperação e disseminação da Informação).

A maioria desses serviços se resume a acervos internos na organização, que não possuem orientações de acesso e pesquisa da Informação e uso das tecnologias. Surge aí a questão da função do Profissional da Informação, que segundo Aranha (2000), vai além da de meros organizadores e controladores do acesso às estantes. Estes devem atuar como portais do conhecimento, quer dizer, devem ser mapeadores e auditores de fontes internas e externas de Informação.

No dia-a-dia, esse profissional precisa analisar dados e informações, comunicar-se intensivamente com os demais componentes de sua equipe e possuir conhecimentos globais do ramo da organização. Dessa forma, analisando mais profundamente a atuação e formação do Profissional da Informação, 
entende-se que é de extrema importância sua readequação para enfrentar as mudanças que vêm ocorrendo no mundo do trabalho. Por isso, segundo Valentim (2000 apud Ferreira, 2002b), a atualização contínua do Profissional da Informação é fundamental.

Complementando essa reflexão sobre as competências do Profissional da Informação, deve-se ressaltar o estudo feito pela SLA, Special Libraries Association, intitulado "Competencies for Special Librarians of the 21st Century" (1996), sobre as habilidades e competências que o profissional deverá desenvolver e apresentar para sua atuação no mercado atual e futuro. Atualmente, tem-se uma edição revisada deste documento, datada de junho de 2003.

Esse estudo apresentou os dois principais tipos de competências para o Profissional da Informação neste novo milênio: profissionais e pessoais.

Profissionais (ou técnicas): identifica-se por um conjunto de conhecimentos sobre os recursos de Informação e o acesso a estes, além de habilidades para usar a tecnologia, a administração e a pesquisa para melhorar e desenvolver novos os serviços e produtos de Informação existentes; Pessoais: conjunto de habilidades, atitudes e valores que permitem aos profissionais da informação trabalhar eficientemente, serem bons comunicadores, compreenderem a importância da educação permanente para a promoção de suas carreiras, compreenderem a natureza de suas atribuições, agregarem valor às informações usadas nas organizações e sobreviverem no novo mundo do trabalho (SLA, 1996).

O SLA (1996 e 2003) construiu uma relação, transcrita a seguir, das principais competências dentro das categorias profissionais técnicas e pessoais: 


\section{Competências Profissionais (técnicas):}

- conhecimento especializado do conteúdo dos recursos de Informação existentes na Biblioteca, incluindo a habilidade de avaliá-los criticamente e filtrá-los;

- conhecimento especializado dos assuntos de interesse da organização onde esse profissional atua;

- habilidade de desenvolver e administrar serviços de Informação convenientes, acessíveis e de baixo custo que estejam alinhados com as orientações estratégicas da organização;

- habilidade para oferecer excelente treinamento e apoio aos usuários dos Serviços de Informação existentes na organização;

- habilidade para levantar necessidades de Informação, desenvolver e vender serviços e produtos de Informação com alto valor agregado, atendendo às necessidades identificadas;

- saber usar a tecnologia da Informação para adquirir, organizar e disseminar informação;

- saber usar abordagens apropriadas de negócios e de marketing para comunicar a importância dos Serviços de Informação para a cúpula administrativa da organização;

- saber desenvolver produtos de Informação específicos para uso interno ou externo à organização ou para clientes individuais;

- saber avaliar os resultados do uso da Informação e conduzir pesquisas voltadas para a solução de problemas de Gestão de Informação; 
- saber aprimorar continuamente os Serviços de Informação em resposta às mudanças nas necessidades;

- ser um membro efetivo da alta gerência e atuar como consultor em questões de Informação dentro da organização.

\section{Competências Pessoais:}

- comprometer-se com a excelência no desempenho de suas atividades profissionais;

- buscar desafios e visualizar novas oportunidades dentro e fora da organização;

- ter uma visão geral e abrangente da organização;

- buscar parcerias e alianças;

- criar um ambiente de respeito mútuo e confiança;

- ter habilidades efetivas de comunicação;

- trabalhar bem em equipe;

- exercer liderança;

- planejar, priorizar e focar os pontos críticos da organização;

- comprometer-se a aprender durante toda a vida e a planejar a carreira pessoal;

- ter habilidade pessoal para negócios e saber criar novas oportunidades;

- reconhecer o valor das redes de contato pessoal e profissional;

- ser flexível e otimista em tempos de mudanças constantes. 
Portanto, fica evidente que os profissionais da área de Ciência da Informação devem revisar o que fazem de melhor e reafirmar o compromisso com a ampliação de suas competências e o crescimento profissional, a fim de que possam agregar valor aos Serviços de Informação que thes são designados e disponíveis a seus usuários. Segundo Santos (2000), tal profissional necessita fazer uso de seus conhecimentos para selecionar os melhores recursos informacionais, sejam eles impressos e eletrônicos - e atender a demanda de Informação de seus usuários com o recurso mais adequado e no tempo certo. Também precisa entender o papel crítico que a Informação tem para as organizações e para os indivíduos e desenvolver uma visão holística das necessidades e dos usos da informação dentro do contexto dessas organizações (FERREIRA, 2002).

De acordo com o estudo do SLA (1996 e 2003), esta nova era abriu oportunidades para as organizações produzirem e usarem novos produtos de Informação. Assim sendo, os Profissionais da Informação podem atuar como os principais colaboradores no desenvolvimento, no marketing e no uso dos produtos de Informação, além de especificar e avaliar sistemas de acesso à Informação que sejam adequados às necessidades de seus usuários. A informação certa no tempo certo pode beneficiar a organização, evitando decisões sem embasamento e perdas financeiras.

O documento da SLA, edição de 2003, destaca também novos tópicos de competências pessoais que estão sendo estudados pelo Comitê de Desenvolvimento de Competências, para a próxima edição do documento. São eles:

- procurar oportunidades novas e desafios no ambiente externo;

- observar o todo: enxergar a Biblioteca ou Serviço de Informação como parte de um grande processo de tomada de decisões; 
- comunicar-se eficazmente; saber apresentar idéias claras, sucintas e entusiásticas através da escrita ou verbalmente;

- apresentar idéias claramente, negociá-las sendo confiável e persuasivo;

- criar parcerias e alianças;

- construir um ambiente de respeito e de confiança mútuos, avaliando a diversidade;

- empregar a aproximação da equipe, reconhecendo e balanceando colaboração e liderança;

- calcular os riscos, mostrando coragem e tenacidade quando enfrentar opositores;

- Planejar, priorizar e focar o que é crítico;

- demonstrar planejamento de carreira pessoal;

- pensar criativamente e inovadoramente, procurar o novo ou reinventar oportunidades;

- reconhecer o valor do trabalho em rede profissional;

- balancear trabalho, família e obrigações comunitárias;

- manter flexibilidade e positivismo em um time de mudança contínua;

- comemorar suas realizações e de parceiros.

Diante dessas competências, e do questionamento do papel do Profissional da Informação nas empresas, mais especificamente na área de Gestão da 
Qualidade, tem-se o início da construção de uma base teórica sólida nacional, que permita um estudo aprofundado do tema, sendo que estudos como estes sobre a Gestão da Qualidade em Serviços de Informação e a participação do profissional da informação em sistemas da qualidade encontra-se com mais frequência em trabalhos internacionais (BROPHY, COULLING, 1996; ST CLAIR, 1996).

Visto o ambiente em que as teorias da qualidade podem ser aplicadas, temse, agora, a atenção voltada para o profissional que pode atuar neste campo. Neste sentido, é importante salientar que esta preocupação com a qualidade não é uma ação nova para os bibliotecários, segundo Whitehall (1992 apud Valls, 1998). Na verdade, a preocupação é discernir "questões de aprimoramento de seu serviço e o estabelecimento de uma nova cultura organizacional centrada na melhoria de serviços, proposta maior da Gestão da Qualidade" (VALLS, 1998).

Segundo Dias e Belluzzo (2003), a edição de 2001 dos Critérios de Excelência do Prêmio Nacional da Qualidade $(P B Q P, 2001)$ possui um item que se dedica ao "Desenvolvimento do Capital Intelectual"; portanto, verifica-se que a capacitação é importante para desencadear o processo de aprendizagem na organização. A ISO 9000 (2000) também corrobora o valor da Informação e do Conhecimento e se preocupa com o tratamento destes aspectos para a tomada de decisões na organização.

Assim, o desenvolvimento das competências do Profissional da Informação, está se tornando cada vez mais importante no ambiente organizacional, principalmente quando estes estudos vêm atrelados aos princípios da qualidade nos Serviços de Informação (DIAS e BELLUZZO, 2003). E para completar tal afirmação tem-se a relação das competências primordiais do Profissional da Informação atuante em empresas, relatada por estes autores:

- noção generalizada da tecnologia, com visão integrada do tratamento e uso da Informação; 
- sensibilidade para antever os vários usos possíveis da Informação e do Conhecimento coletados ou produzidos internamente;

- capacidade de articulação com os diversos agentes do fluxo e ciclo da Informação (geração, coleta, armazenamento, disseminação e acervo);

- conhecimento das técnicas e recursos das Tecnologias da Informação (redes, hipertexto, hipermídia, recuperação e armazenamento de texto, arquivamento eletrônico de documentos e novas mídias de armazenamento);

- capacidade de análise e síntese;

- mecanismos para contornar o problema da relevância da Informação face ao seu crescente volume;

- familiaridade com a estrutura, categorização, indexação, fontes de informação, mecanismos de transferência de dados e com os softwares disponíveis.

Finalizando a abordagem sobre as competências e dando início a outra temática da revisão de literatura desta pesquisa, citamos Santos (2000, p.116) que afirma: "todas as oportunidades do mercado de trabalho estarão abertas para o Profissional da Informação, Bibliotecário, que possuir um projeto de vida profissional em que a educação continuada seja meta permanente". Portanto, realiza-se a seguir uma análise sobre a Educação Continuada no processo de aprimoramento dos conhecimentos técnicos desses profissionais, para atuação com a Gestão da Qualidade em Serviços de Informação. 


\subsection{A Educação continuada e o Profissional da Informação}

Neste item da revisão de literatura foi realizada uma reflexão sobre o processo de formação continuada do Profissional da Informação, complementando os enfoques sobre as competências, perfil e formação neste novo milênio, ressaltando alguns trabalhos importantes que destacaram especificamente esta temática, analisados a seguir.

Durante muito tempo, a "educação formal básica foi considerada tarefa para um período etário no qual o homem completaria sua educação no sentido de atender à exigência de aquisição de conhecimentos, hábitos e maneiras de viver aceitos pela sociedade" (SILVA, s.d.).

Silva (s.d.) ainda afirma que: "a formação universitária não deveria ser vista como o ponto final, mas como o ponto de partida que determina, como prática, a qualidade do processo como um todo". E acredita que "o estudante deva receber durante seu curso todas as informações necessárias para o exercício satisfatório de sua profissão na sociedade". Portanto, esta educação pode ser vista como a "reconstrução ou reorganização de experiências, que esclarece e aumenta o sentido destas" e também que "a aptidão do homem para dirigir o curso de experiências sucessivas" (SILVA, s.d.). Ou seja, a educação "deveria sair do campo exclusivo dos conhecimentos e situar-se na própria vida cotidiana".

Diante destas afirmações, conceitua-se a educação continuada, como "atividades formais e informais de aprendizagem, através das quais os indivíduos elevam seus conhecimentos, atitudes e competências (STONE,1986). Ou seja, a educação continuada é aquela que "se faz ao longo da vida, para propiciar a atualização e prevenir a obsolescência do profissional".

A educação continuada reforça o currículo, garante atualização profissional e mais conhecimento, proporcionando novas oportunidades no mercado e na 
própria vida. Além disso, manter-se permanentemente atualizado é quase uma questão de sobrevivência hoje na sociedade brasileira, que passa por transformações significativas, com reflexos no mercado de trabalho e na competência exigida dos profissionais.

A educação continuada não está só relacionada ao exercício da profissão, mas também à ampliação da capacidade de se auto-realizar, desenvolver outros conhecimentos e aptidões que completem a própria pessoa e tragam o reconhecimento perante a sociedade.

Historicamente, o conceito de educação continuada para o Profissional da Informação surgiu em 1876, com a fundação da ALA, American Library Association. Esta associação estabeleceu os primeiros padrões de formação para as escolas. Hoje, por exemplo, o tema "educação continuada" é pauta em importantes seminários e congressos da área de Biblioteconomia e Ciência da Informação.

Em 1898, Dewey já defendia a necessidade de educação continuada para os Profissionais da Informação; o trabalho de Kremer (1983), em que a autora compara a formação do profissional nos Estados Unidos e no Brasil, espelha isso. Segundo ela, em 1954 o IBBD (Instituto Brasileiro de Biblioteconomia e Documentação, hoje IBICT) instaurou Cursos de Especialização e, finalmente, em 1970, criou o primeiro Curso de Mestrado em Ciência da Informação. O primeiro curso de Mestrado em Biblioteconomia foi criado em 1976 na Universidade Federal de Minas Gerais. Posteriormente, surgiu o curso da Pontifícia Universidade Católica de Campinas, Universidade de Brasília e Universidade Federal da Paraíba.

Segundo Valentim (2000), a educação continuada do Profissional da Informação, "é fundamental" e são caminhos que o profissional pode percorrer para sua devida adequação à realidade empresarial. A autora ainda constata que 
a educação continuada está consolidada nacionalmente, justamente pelo grande número de cursos existentes, que englobam: Extensão e Atualização; Pósgraduação Lato-sensu e Stricto-sensu. Portanto, o grande desafio é "referente à capacidade dos cursos de formação profissional em desenvolver/ajustar seus currículos e cursos de educação continuada às mutações da sociedade de forma a abranger todas as nuanças da área de informação e responder às necessidades dos profissionais". (ARRUDA, MARTELETO e SOUZA, 2000). No entanto, é necessário adequar-se à realidade. Sabe-se que a Lei de Diretrizes e Bases para a Educação (LDB), de 20/12/1996, vem debatendo, desde então, as diretrizes curriculares para a área de Ciência da Informação.

Segundo Porto (2000), a formação se dá enquanto acontece a prática, ou seja, ela não se conclui jamais e a cada momento de reflexão abrem-se possibilidades para novos momentos de formação, com a prática se tornando o "gancho" para a produção do Conhecimento.

Mcgregor (1992, p.194), diz que "todo profissional está empenhado no uso do conhecimento para a consecução de objetivos". Qualquer profissional pode recorrer tanto ao conhecimento científico pessoal e de outros, quanto ao conhecimento obtido através da própria experiência. Considera-se que a primeira fonte é a que dá subsídios para o perfil do profissional. Assim sendo, Mcgregor (1992), considera que:

A aquisição de conhecimento é um processo bastante simples e direto, desde que o indivíduo deseje o novo conhecimento; pois, terá dificuldade de absorver conhecimento aquele profissional que não souber o quanto precisa dele.

Trazendo agora essa reflexão ao contexto da Educação Continuada dos Profissionais da Informação e à relação destes com a capacitação para a Gestão da Qualidade, tem-se que, principalmente no meio empresarial, a capacitação e conhecimento nesta área de atuação é imprescindível. Para justificar essa necessidade, Vergueiro (2002) destaca que é necessário "priorizar a capacitação 
do pessoal para a qualidade e serviço ao cliente". Ou seja, o profissional deve reconhecer a necessidade de adquirir conhecimento nesta área específica, por exemplo. E este deve possuir incentivos - pessoais e da própria organização - e possuir acesso a cursos e programas patrocinados pela organização, visando suprir às suas necessidades.

Outro estudo importante sobre o assunto é o de Belluzzo (1995), no qual a autora trabalhou dois focos: a Gestão da Qualidade e a capacitação de recursos humanos, constatando que a formação na qualidade é essencial para o trabalho nas organizações.

\subsubsection{Mudanças no padrão de qualificação do Profissional da Informação: intercâmbios de conhecimento e desenvolvimento curricular}

Os Profissionais da Informação estão sendo instados a reafirmar sua importância e seu valor para o mundo do trabalho, em meio à transição para um novo modelo de qualificação profissional. É evidente que sempre haverá controvérsias, e uma delas que vem permeando a área da Informação é a retirada de qualquer referência à palavra Biblioteca do nome das instituições de formação profissional, que passariam a ser nomeadas pela expressão Informação ou por Ciência da Informação. O argumento que respalda esta mudança é que a palavra Biblioteca restringe o âmbito de atuação dos profissionais e dificulta a identificação dos mesmos pelo mercado de trabalho, para atuação em outros espaços profissionais.

A tese contrária a essa alteração destaca que o estudo da Informação como fenômeno não fornece o suporte teórico necessário para a complexidade que envolve o conceito de Biblioteca (Crowley e Brace, 1999). Para complementar tal afirmação, a partir de 2007, os Conselhos Regionais, não estão mais autorizando o exercício da profissão aos cursos que formam em Ciência da Informação com habilitação em Biblioteconomia; ou seja, não existe a regulamentação da profissão 
e seria necessário um Conselho Regional para o Cientista da Informação; tal medida depende agora da ação das Diretorias das Faculdades que formam o Cientista da Informação.

Vale reafirmar aqui, novamente, que com o objetivo de identificar como os Profissionais da Informação estão lidando com as mudanças no mundo do trabalho e em seu perfil profissional, a Federação Internacional de Informação e Documentação (FID) criou, em 1991, o Grupo de Interesse Específico sobre Papéis, Carreiras e Desenvolvimento do Moderno Profissional da Informação (SIG FID/MIP), e este grupo realizou uma pesquisa mundial, entre os profissionais da área, para identificar seu perfil "moderno".

No item da pesquisa da FID relativo às mudanças que estão ocorrendo no conteúdo do trabalho nos últimos cinco anos, a tecnologia desponta como a propulsora das principais modificações, seguida por elementos de gestão organizacional e do trabalho. Com relação à educação continuada, esta ocorre principalmente no ambiente de trabalho e é mais voltada para a assimilação de ferramentas gerenciais.

Para finalizar esta revisão de literatura, é importante salientar que estes fatos sinalizam para um desafio referente à capacidade dos cursos de formação profissional para desenvolver/ajustar seus currículos e cursos de educação continuada às mutações da sociedade, visando à abrangência de todas as nuanças da área de Informação e responder às necessidades dos profissionais, sendo que a educação continuada envolve a formação tanto do profissional quanto do docente que forma este profissional, já que o segundo faz o papel de agente de mudanças. Assim, foi possível fazer o levantamento do contexto relacionado com a atuação e com a aprendizagem continuada do profissional objeto desta pesquisa e tais contextos foram analisados nos capítulos seguintes. 
A pesquisa, de caráter qualitativo-exploratório, propôs-se a trabalhar com etapas para melhor redirecionar os aspectos metodológicos quanto à obtenção dos resultados e objetivos. Estas etapas por sua vez, foram: a revisão de literatura baseada nos aspectos pertinentes, ou seja, o Profissional da Informação e a Gestão a Qualidade em Serviços de Informação e, além da revisão, foi desenvolvido um estudo exploratório, para complementar e atingir de maneira mais significativa os objetivos da mesma.

O estudo exploratório teve como objetivos:

- realizar uma pesquisa de campo para buscar Profissionais da Informação atuantes em empresas e, a partir disso, pesquisar suas condições de atuação e capacitação, por meio da aplicação de questionário;

- tabular e analisar os dados obtidos com o questionário aplicado: descrevendo todas as etapas e perguntas do questionário, fazendo um paralelo com os objetivos e hipóteses da pesquisa;

- buscar os cursos de capacitação para o profissional da informação que tenha, como objetivo, formá-lo na área de Gestão, ou seja, tudo que envolva a formação voltada para o mercado atual, sendo uma delas a formação para a Gestão da Qualidade;

- contrapor o tópico da capacitação do profissional da Informação, relacionando os dados obtidos e a pesquisa de campo sobre as instituições e escolas que formam este profissional.

Trabalhou-se, portanto, com dados oriundos da literatura sobre o objeto em estudo e das informações coletadas por meio do questionário somente como 
caráter comprobatório das hipóteses levantadas, já que se trata de uma pesquisa qualitativa.

\subsection{Método}

Nesta pesquisa, utilizou-se a abordagem qualitativa, pois Godoy (1995) afirma que esta é uma forma adequada para entender a natureza de um fenômeno social. E corresponde, também, a uma metodologia de pesquisa não estruturada baseada em pequenas amostras e que fornecem insights e compreensões do problema abordado. Assim, o método qualitativo é a resposta quando se visa a conhecer as motivações do público-alvo, investigando a fundo conceitos e idéias. Suas principais funções são testar as hipóteses levantadas e investigar os assuntos em profundidade, avaliando os fatores emocionais e intencionais no objeto pesquisado (GOMES, 1997).

Com base na análise de Gil (1987, p.44), define-se como estudo exploratório aquele que tem por finalidade "desenvolver, esclarecer e modificar conceitos e idéias, com vistas à formulação de problemas mais precisos ou hipóteses pesquisáveis para estudos posteriores". Portanto, a abordagem qualitativa constituiu o método desta pesquisa, pois foram realizados estudos exploratórios em que foram demonstradas as multiplicidades de dimensões presentes no objeto pesquisado, utilizando os dados coletados e tratados. 


\subsection{Pré-teste}

No exame de qualificação desta pesquisa foram levantadas algumas sugestões quanto ao método para a coleta de dados. A Banca fez a sugestão de se trabalhar com o método de Grupo Focal.

Mas, não se optou por tal método devido à dificuldade de estar reunindo numa mesma data e local o sujeito da pesquisa. Ou seja, optou-se por manter o método de coleta de dados levado a banca, que foi a aplicação do questionário, enviado por e-mail. A opção pelo questionário deveu-se ao fato de que o universo em estudo está disperso no Estado e também se levou em conta o tempo disponível, a flexibilidade e a facilidade quanto ao envio das respostas das pessoas envolvidas já que a maioria possui pouca flexibilidade de horário. Naturalmente, foi necessário monitorar as respostas através de correio eletrônico (e-mail), sendo este também o meio de envio do questionário aplicado.

Assim sendo, para a validação do instrumento de pesquisa, foram realizados dois pré-testes, antes da aplicação definitiva do questionário aos profissionais. Este foi realizado entre os meses de maio e junho de 2006, com o objetivo de verificar a clareza e a objetividade do instrumento elaborado. A partir deste pré-teste, algumas alterações foram realizadas na formulação do questionário sem, no entanto, modificá-lo em sua estrutura. 


\subsection{Universo e Sujeito da pesquisa}

O universo total da pesquisa foi de sete (7) Empresas/ Organizações / Instituições, limitando a localização ao Estado de São Paulo.

Tal amostra intencional foi realizada seguindo os critérios para a seleção das empresas, a seguir:

1) certificação da qualidade (ISO, etc.) através de consulta ao Banco da ABNT de Empresas Certificadas;

2) possuir Biblioteca ou Centro de Documentação liderado por um Profissional da Informação, Bibliotecário, o que limitou bastante o número do universo e sujeitos analisados.

Dentre esses critérios, foram selecionadas as seguintes organizações, para o envio da carta de apresentação para a participação do Profissional da Informação na pesquisa:

\section{Petrobrás \\ Fiocruz \\ Vivo \\ CPFL Energia \\ MetLife Seguradora \\ Câmara Municipal de São Paulo}

O sujeito da pesquisa foi o Profissional da Informação, atuante nas referidas organizações. E para se chegar a estes profissionais especificamente, os critérios utilizados foram os baseados na escolha do universo, que foi a primeira seleção feita. Ou seja, que atuassem nas Bibliotecas ou Centros de Informação de organizações, pois esta pesquisa tem o objetivo de estudar o mercado emergente 
do profissional e não o tradicional, discutindo experiências práticas nestes ambientes, pouco explorados pelo Profissional da Informação advindo da área de Ciência da Informação.

\subsection{Coleta de dados}

A Coleta de dados foi realizada, focando nos objetivos específicos desta pesquisa, para se chegar ao principal, que foi analisar a capacitação do Profissional da Informação, Bibliotecário, na área de Gestão da Qualidade em Serviços de Informação.

Para tanto, utilizou-se do instrumento básico usado em pesquisa social, o questionário (Apêndice 1), que foi enviado aos Profissionais da Informação atuantes ou responsáveis por Bibliotecas ou Centros de Informação da organização.

Assim, em um primeiro momento, identificou-se, depois de escolhida a organização e contactado o seu profissional, o nível de atuação do Profissional da Informação, Bibliotecário, na área de Gestão da Qualidade em Serviços da Informação.

Em um segundo momento, identificou-se a oferta de cursos extracurriculares sobre Gestão da Qualidade em Serviços de Informação, via Internet através do buscador Google, através do qual foram listados os cursos e analisadas as formas de educação continuada do profissional, incluindo as instituições formadoras - públicas ou privadas - que ofereçam cursos voltados para a área de Gestão da Qualidade.

\subsection{Instrumento da pesquisa}


A pesquisa teve como instrumento de coleta de dados um questionário (Apêndice 1), semi-estruturado, para facilitar as respostas às perguntas de múltipla escolha, permitindo comentários e opiniões além das alternativas impostas, forma de enriquecimento da pesquisa, que identificou o profissional, sua área de formação, capacitação e sua atuação com a Gestão da Qualidade.

O questionário contou com quatro partes: a primeira foi reservada à identificação e formação do profissional; a segunda visou identificar as características da atuação do profissional, também relacionando a Gestão da Qualidade; a terceira parte disse respeito à capacitação do profissional; a quarta e ultima parte foi destinada às competências em Gestão.

Tendo por objetivo trazer informações sobre as tendências, perfil e as competências em Gestão da Qualidade relacionadas ao Profissional de Informação no mercado emergente, vista pelo próprio profissional, o questionário enviado buscou coletar os seguintes dados:

1. os serviços que a Biblioteca e/ou Centro de Informação especializado oferece ao seu usuário;

2. avaliação dos usuários dos serviços prestados;

3. trabalho voltado para os conceitos básicos visando a qualidade;

4. técnicas e programas da qualidade utilizadas;

5. ferramentas da qualidade utilizadas;

6. nível de preparação pessoal para aplicação dessas técnicas, programas e ferramentas; 
7. conhecimentos específicos para se trabalhar com vista para a qualidade;

8. cursos realizados ou a serem desenvolvidos sobre Gestão da Qualidade;

9. disponibilidades para a educação continuada;

10. competências para atuar com a Gestão da Qualidade.

Os dados foram coletados, no início do mês de julho de 2006, por meio de correio eletrônico. Foi estipulado um prazo - até o início do mês de agosto de 2006 - para que os sujeitos da pesquisa devolvessem o questionário, sugerindo-se que o mesmo fosse enviado também via correio eletrônico.

O questionário foi enviado juntamente com uma carta de apresentação (Apêndice 2) informando sobre o objetivo da pesquisa, e, após o recebimento do questionário respondido, foi enviada uma carta de agradecimento (Apêndice 3).

Depois destes dados coletados, foi possível analisar os dois últimos objetivos: identificar as carências no processo de formação e qualificação do Profissional da Informação e sua inserção no mercado, analisando as exigências de conhecimentos técnicos e pessoais baseados nos estudos internacionais da Special Libraries Association, SLA e refletir sobre o processo de qualificação do Profissional da Informação que atuará e dos que já atuam em organizações voltadas para a Gestão da Qualidade em Serviços de Informação. 
4 Análise e Interpretação dos dados 
No caso deste estudo exploratório, levou-se em conta não a quantidade e sim a qualidade da pesquisa de campo, que contou com uma escolha intencional dos sujeitos, além do diferencial de utilizar um instrumento de coleta de dados com respostas de múltipla escolha. Como tal pesquisa fundamentou-se no trabalho do Profissional da Informação em relação à sua atuação na área da Gestão da Qualidade, os dados que foram coletados, analisados e interpretados estão ancorados nos aspectos que norteiam a educação continuada deste profissional nesta área.

\subsection{Pesquisa sobre a atuação do Profissional da Informação}

\subsubsection{Identificação e Perfil Profissional}

As primeiras perguntas do instrumento de coleta de dados (Apêndice 1) tiveram o propósito de identificar Profissionais da Informação atuantes em organizações ou empresas, para saber o nível de atuação deste profissional na área da Gestão da Qualidade.

Como já foi demonstrado na metodologia, foram contactados Profissionais da Informação, Bibliotecários, responsáveis e atuantes em Centro de Informação especializado, ou Bibliotecas das seguintes organizações: Fiocruz, Petrobrás, Vivo, CPFL Energia, Metlife Seguradora e Câmara Municipal de São Paulo. Assim, obteve-se um total de seis (6) profissionais identificados, atuantes no cargo de gerência, responsáveis pelo Centro de Informação e /ou Biblioteca e todos com formação em Biblioteconomia. A maioria também trazia, na história profissional, pelo menos um curso de Pós-graduação realizado (na maioria lato sensu). Uma única respondente não o possuía. Já de início, pôde-se detectar que a busca pela educação continuada faz parte da realidade da maioria dos Profissionais da Informação atuantes neste mercado emergente da profissão.

Os cursos são variados, mas destaca-se dentre eles aqueles voltados para a Gestão da Informação, Gestão de Sistemas de Informação, Marketing, Gestão 
de Arquivos Empresariais e Inteligência Competitiva. Todos os profissionais realizaram os cursos entre 2003 e 2006. Assim, pode-se verificar que a tendência por essas temáticas na busca pela educação continuada começou a crescer nestes últimos anos.

\subsubsection{Atuação Profissional}

Na parte II do instrumento de coleta, há o tópico que diz respeito à atuação profissional dos sujeitos.

A primeira questão buscou contemplar os serviços que o Centro de Informação ou Biblioteca oferece a seus usuários, especificamente, para caracterizar este segmento de atuação e verificar se os serviços oferecidos neste mercado se equiparam àqueles oferecidos no mercado tradicional. Dentre as opções que a questão contemplava, destacam-se: pesquisa bibliográfica, atendimento, consulta e empréstimo; pesquisa em banco de dados/periódico eletrônico e outros. O gráfico a seguir demonstra os serviços oferecidos. Pôde-se concluir que os serviços clássicos - como "atendimento, consulta e empréstimo" são os mais oferecidos também neste cenário de atuação.

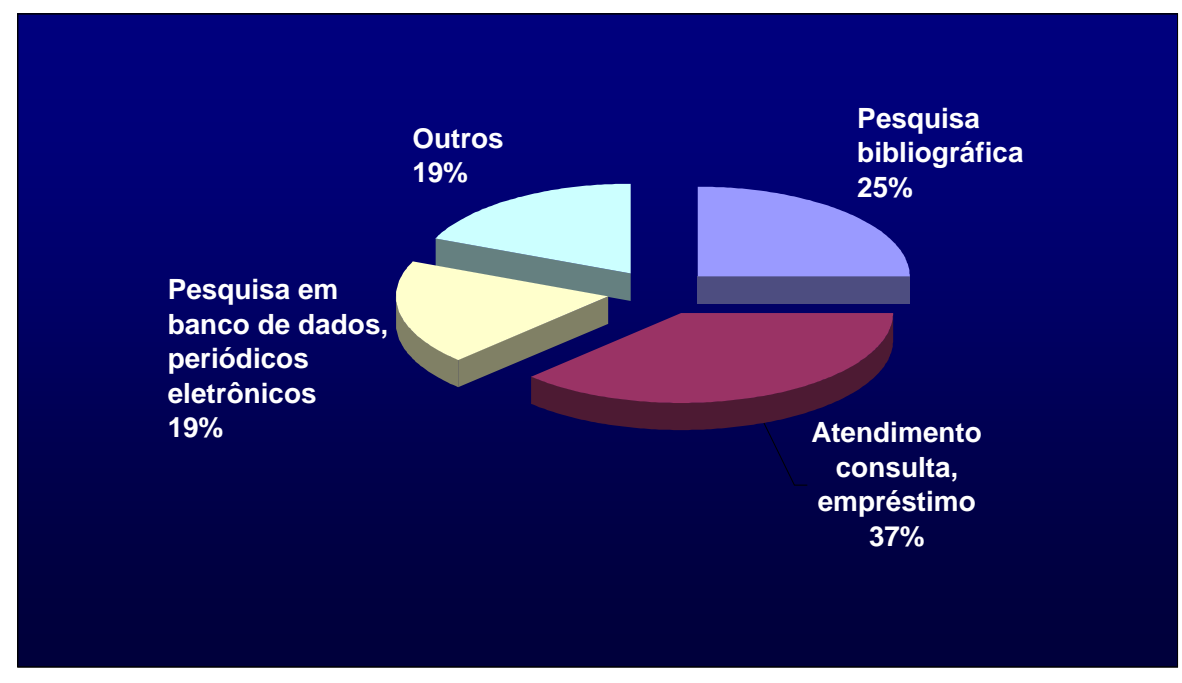

Gráfico 1: Serviços de Informação 
Por outro lado, como diferencial, na questão aberta que distinguiu "outros serviços" foram destaques, como respostas além das opções apresentadas, vários serviços oferecidos, como: GED (Gestão eletrônica de documentos), oferecimento de projetos de organização documental e treinamentos aos usuários. Em outra empresa, temos a particularidade de que a Biblioteca não é constituída "físicamente", em que os "Centros de Informações se constituem em conjunto com a Gerência de Inteligência Estratégica e atendem a demandas de informação do cliente interno". Em uma outra empresa, são oferecidos também serviços com relação ao GED e pesquisa em banco de dados de imagens.

\subsubsection{Avaliação dos usuários em relação aos serviços prestados}

A questão seguinte (2.2) teve o objetivo de verificar se o profissional avaliava a satisfação do usuário quanto aos serviços prestados pela Biblioteca ou Centro de Informação.

A maioria respondeu afirmativamente, ou seja, que avalia de alguma forma a satisfação dos usuários com os serviços prestados por sua Biblioteca. Apenas uma profissional respondeu que, ao invés de avaliação, ela tem um "feedback se os produtos (análises) enviados, atenderam as expectativas". Portanto, com essa questão constata-se que de alguma forma são feitas avaliações que visem à qualidade e à melhoria nesses Serviços de Informação, com foco na satisfação do cliente.

Assim, como continuação da questão anterior, buscou-se verificar as formas de avaliação dos serviços prestados, ou seja, as ferramentas utilizadas pelo profissional, para buscar conhecer a opinião do usuário (2.3 Como você avalia esses serviços prestados ?) e estas são apresentadas no gráfico 2. 


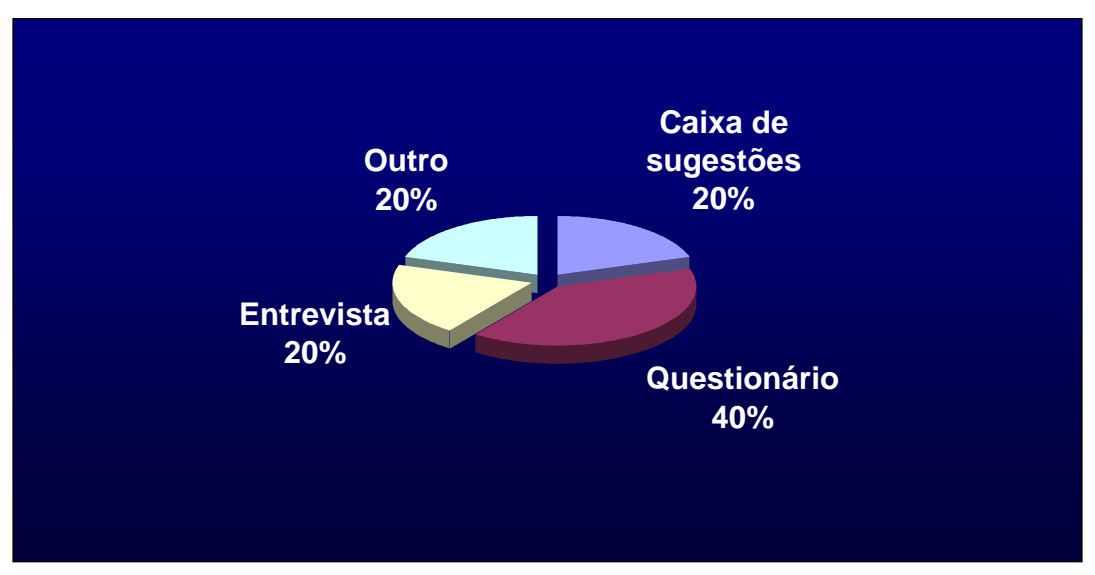

Gráfico 2: Métodos para avaliação dos Serviços de Informação

O questionário é o instrumento mais utilizado; talvez pelo fato de ser, muitas vezes, impessoal e informal, podendo ser aplicado para grandes grupos ou via email. É mais completo e eficaz, se bem elaborado, no que diz respeito à obtenção de um quadro geral do nível de satisfação dos serviços. E, se bem trabalhado, pode fornecer informações imprescindíveis a respeito da qualidade dos Serviços de Informação e ser uma "alavanca" que impulsione a melhoria contínua dos serviços prestados.

No campo "Outros", também foram citados, como formas de avaliação dos serviços a "Avaliação periódica de desempenho", e o "feedback" que a empresa recebe de seus clientes, via e-mail. Também temos um outro procedimento citado que vale a pena destacar, que seria a aplicação do questionário via correio eletrônico para as áreas técnicas da empresa, consideradas formadoras de opinião e do acervo da Biblioteca.

\subsubsection{Trabalho voltado para os conceitos básicos visando à qualidade}

Com relação a esta questão especificamente (2.2 No seu dia-a-dia, você procura trabalhar de forma a utilizar conceitos básicos visando à qualidade quando procuram os serviços de sua Bibliotecal Centro de Informação?), pudemos verificar que $100 \%$ dos Centros de Informação / Bibliotecas que participaram da 
pesquisa e seus profissionais trabalham com vistas à qualidade. Esses "conceitos básicos" têm relação com as perguntas anteriores, sobre a avaliação da satisfação do usuário e como estes são avaliados, partindo-se da premissa de que um conceito básico da qualidade tem a ver com a avaliação dos serviços prestados pela Biblioteca para sua melhoria contínua. Como na pergunta anterior, todos, de alguma forma, afirmaram avaliar seus serviços, pode-se inferir que a preocupação com os conceitos básicos da qualidade foi, ainda que indiretamente, contemplada.

De acordo com a literatura revista, realmente "tudo caminha para a qualidade" e pode-se dizer que a Qualidade ou Gestão da Qualidade é uma prática administrativa que ainda está se inserindo nas organizações privadas, sob todos os enfoques (capital intelectual, responsabilidade social, segurança e saúde do trabalhador). Assim, os Serviços de Informação dessas organizações também necessitam instituir esta rotina. Por isso, o próximo tópico contempla mais especificamente como se dão essas práticas.

\subsubsection{Técnicas e programas da qualidade utilizadas}

Nesta pergunta, o intuito foi saber se o profissional conhece e já utilizou técnicas e programas voltados para a qualidade no ambiente de trabalho, com o objetivo de, também, avaliar os seus serviços e produtos (2.3 Você já utilizou algumas dessas técnicas ou desenvolveu algum desses programas no seu dia-adia ?). 


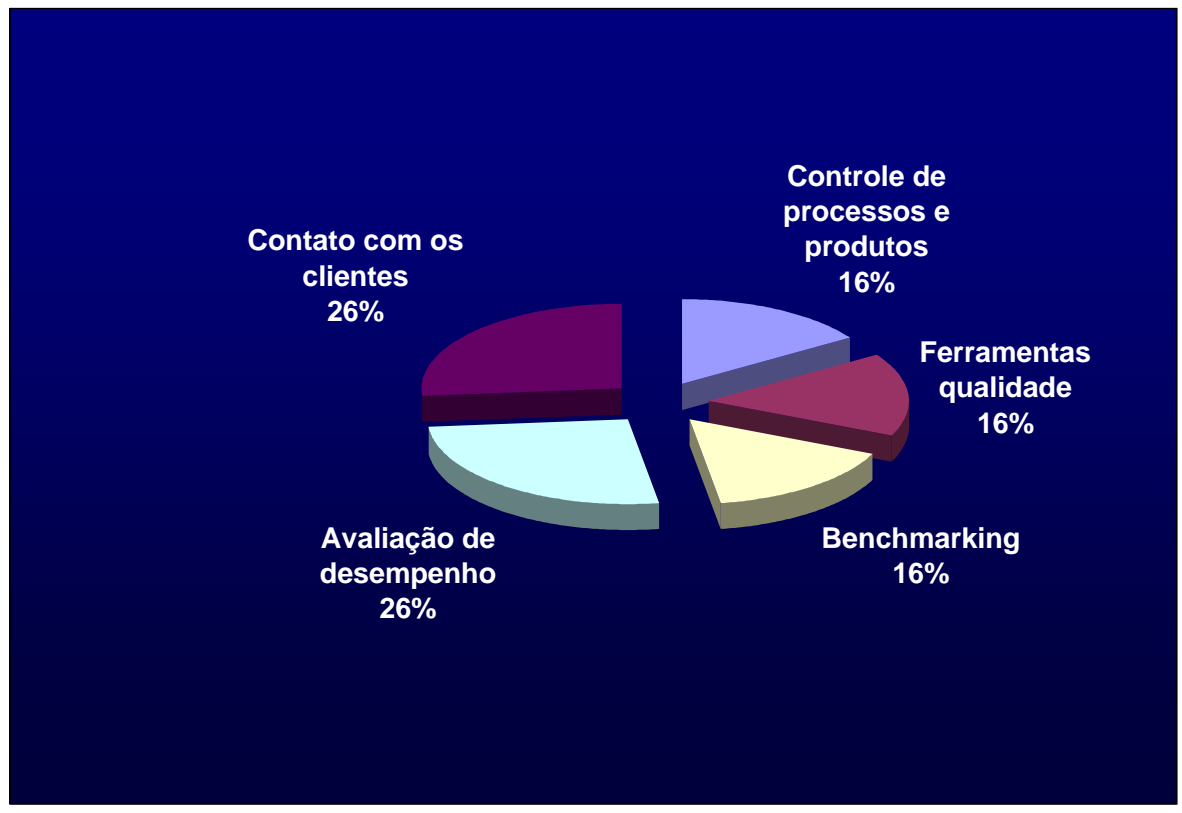

Gráfico 3: Técnicas da Qualidade utilizadas nos Serviços de Informação

Percebe-se que o profissional, em algum momento, já utilizou uma dessas técnicas, sendo que a maioria prefere o contato com os clientes e a avaliação de desempenho. Em segundo lugar, temos técnicas específicas, como as ferramentas da qualidade, benchmarking e controle de processos e produtos, também já utilizadas por alguns dos profissionais. Tem-se, com essa questão, que algumas técnicas, como o contato com os clientes, deixam a avaliação dos serviços um tanto quanto vaga; nesse sentido, as ferramentas da Qualidade poderiam ser instrumentos mais confiáveis de retorno para a Biblioteca que avalia seus serviços, ou seja, os profissionais se limitam a utilizar as técnicas mais informais, deixando em segundo plano as técnicas formais. Talvez o motivo para tal circunstância seja o desconhecimento ou até mesmo a falta de interesse em utilizar tais técnicas.

\subsubsection{Ferramentas da Qualidade utilizadas}


Nesta pergunta especificamente sobre as ferramentas da Qalidade, o objetivo foi conhecer as que já foram utilizadas no cotidiano do gerenciamento do Centro de Informação/ Biblioteca da organização, pelos profissionais (2.4 Você já utilizou alguma dessas ferramentas específicas da qualidade para avaliação e diagnóstico de seu Serviço de Informação?).

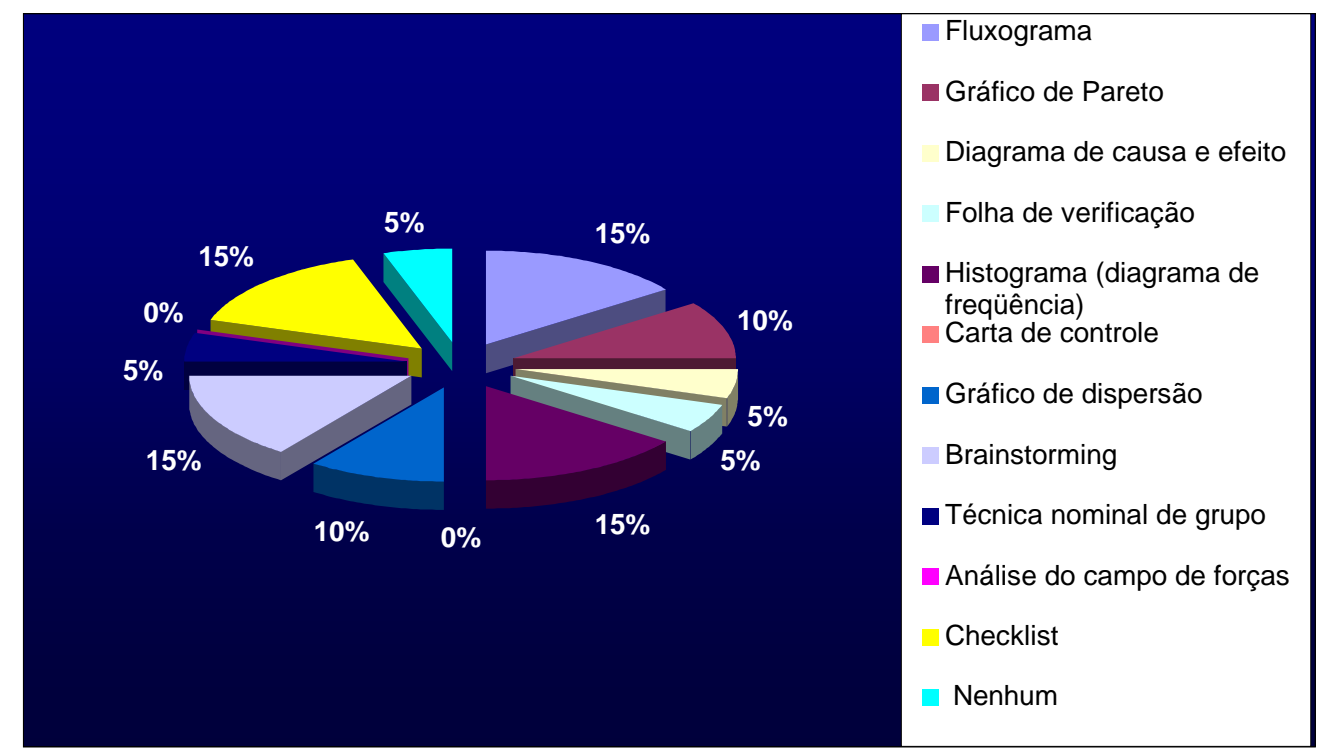

Gráfico 4: Ferramentas da qualidade utilizadas no Serviço de Informação

Pôde-se detectar que a maioria utilizou pelo menos uma dessas ferramentas. Sendo que as mais utilizadas foram: Fluxograma, Histograma (diagrama de freqüência), Brainstorming, Checklist. Em seguida, as menos utilizadas foram: Gráfico de Pareto, Diagrama de causa e efeito, Folha de verificação, Gráfico de dispersão, Técnica nominal de grupo. As nunca utilizadas foram: Carta de controle e Análise do campo de forças, talvez até por desconhecimento dessas ferramentas. E há um profissional nunca utilizou qualquer uma das ferramentas relacionadas, mesmo que avalie a satisfação de seus usuários, conforme analise da pergunta 2.2.

Constata-se aqui que as ferramentas mais utilizadas, realmente, são as mais citadas na literatura de relatos de experiência, sendo elas: Benchmarking, 
gestão de relacionamento com o cliente, SERVQUAL/ LibQUAL, 5S. (BARBÊDO e VERGUEIRO, 2006). Talvez o profissional acredite nestas técnicas, tentando trazê-las ao dia-a-dia do seu trabalho em Serviços de Informação, mas acredita-se também que, por outro lado, há falta de conhecimento, por parte do Profissional da Informação, de outras categorias de ferramentas que possam ajudar no cotidiano e que não são empregadas.

Assim, segue-se para outro tópico que, talvez, poderá justificar o conhecimento das ferramentas e técnicas por alguns desses profissionais.

\subsubsection{Nível de preparação pessoal para aplicação dessas técnicas, programas e ferramentas da Qualidade}

Nesta questão foi lançada a pergunta 2.5 Você se sentiu preparado para aplicar técnicas/ desenvolver projetos voltadas para a Gestão da Informação ou da Qualidade quando precisou? Gostaríamos de saber sobre a preparação pessoal do profissional para a aplicação dessas técnicas, programas e ferramentas da qualidade.

Constata-se que $100 \%$ dos profissionais responderam estarem preparados para o desenvolvimento dessas técnicas. Mas será que efetivamente estão? Vê-se que a grande maioria opta por técnicas informais de programas voltados para a qualidade e não utilizam métodos específicos, como a aplicação de ferramentas,

por exemplo. A grande questão é: será que esses profissionais têm realmente o conhecimento dessas técnicas, e sabem utilizá-las com vistas à qualidade ?

É importante destacar que as técnicas e ferramentas para a qualidade são suporte e cotidiano desses profissionais no seu ambiente de trabalho, e, de acordo com a pesquisa, os profissionais consideram-se aptos a aplicá-las. 
Assim, objetivou-se saber, com a próxima pergunta, as formas de capacitação, ou seja, as primeiras constatações sobre a qualificação desse profissional na área da Gestão da Qualidade (2.6 Como se preparou para aplicar ou desenvolver projetos voltadas para a Gestão da Informação ou da Qualidade?).

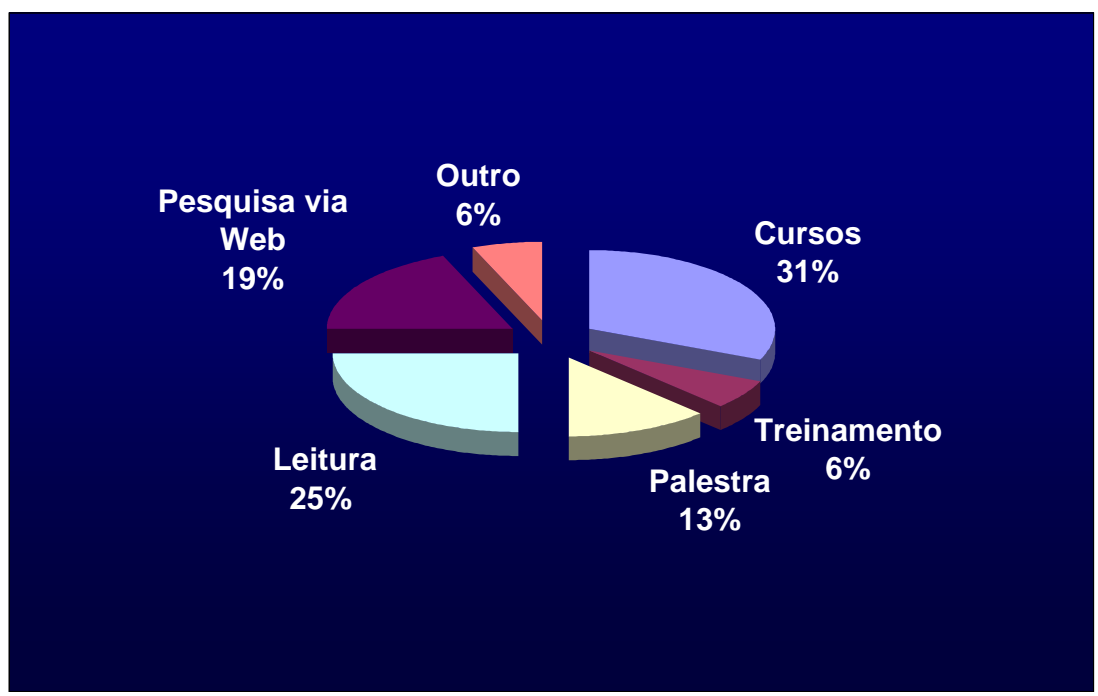

\section{Gráfico 5: Métodos de capacitação para atuar com Gestão da Qualidade em Serviços de Informação}

Segundo o gráfico acima, pode-se afirmar que a maioria dos profissionais se preparou, ou se prepara e se qualifica por meio de cursos, ou seja, esta é a forma mais procurada pelo profissional para a educação continuada. Acredita-se também ser esta a mais eficiente forma de adquirir conhecimento, principalmente, quando são cursos com mais de 360 horas, caracterizados como cursos de Pósgraduação ou Especialização.

Também pode-se considerar leituras, palestras, treinamentos e pesquisas via web, como formas de educação continuada para atuação com Gestão da Qualidade e que também estão presente no cotidiano de preparação do Profissional da Informação.

Vale mencionar que um dos profissionais entrevistados considerou que a preparação também pode vir dos "conhecimentos já adquiridos na graduação e 
expertise no mercado". Não pontuou ou demonstrou interesse por nenhum tipo de educação continuada para esta área específica, mas somente afirmou que é importante estar qualificado para a atuação com Gestão da Qualidade.

\subsubsection{Conhecimento específico para se trabalhar com vista para a Qualidade}

Para reafirmar o tópico da preparação do profissional para a atuação em seu trabalho com foco para a qualidade, julgou-se necessário saber dos profissionais se é importante ter conhecimento específico no assunto (3.2 Você acha que é necessário conhecimento específico, curso ou capacitação para atuar com a Gestão da Informação e a Gestão da Qualidade?). Todos os profissionais entrevistados responderam afirmativamente, ou seja, que é importante estar preparado e qualificado para a atuação com Gestão da Qualidade.

Ainda houve um profissional que complementou afirmando que é importante "principalmente para profissionais que trabalham diretamente com controle documental (Centro de Documentação, Arquivos, etc), no meu caso, o foco é muito mais gestão da informação (conteúdo)". Portanto, temos a nítida impressão que o profissional tem conhecimento sobre a importância desta prática no seu diaa-dia, mas talvez não o conhecimento de como aplicá-la no seu Serviço de Informação. Então, o que falta para esses profissionais? Acesso às ofertas de educação continuada?

Passa-se assim, para a próxima questão que foi saber, diante das formas de preparação para atuação com a Gestão da Qualidade, os cursos a que estes profissionais recorreram. 


\subsubsection{Cursos realizados para atuação profissional}

Da pergunta sobre os cursos e capacitações já realizados voltados para a qualidade (3.1 Você já realizou algum curso/treinamento específico para atuar com a Gestão de Informação ou da Qualidade?) houve um relato dos cursos que estes profissionais já realizaram para atuação nesta área. Praticamente todos os profissionais tinham um curso realizado, podendo ser eles de especialização ou cursos técnicos. Somente um profissional não realizou cursos voltados para esta área, pois justificou não lidar com a Gestão Documental, e sim, com as áreas de Publicidade e Marketing.

Assim, estão listados abaixo os cursos que cada profissional respondente já realizou:

\section{1 - Especialização em Gestão da Informação e curso de Qualidade Total}

2- Padronização para a Gestão Da Qualidade - Curso De Extensão -Faculdade de Engenharia Mecânica - Unicamp

3- Gestão do conhecimento, Gestão de base de dados, Gerenciamento Eletrônico de Documentos

4- Gestão de Projetos, Gestão da Qualidade Total, Gestão do conhecimento, Gestão da Informação

\section{5- Pós-Graduação na FESP}

Pode-se constatar que os profissionais realizaram alguns cursos específicos na área da Gestão da Qualidade, como também cursos que englobam outros focos, como: a Gestão do Conhecimento, Gestão da Informação, Gestão de 
Documentos Eletrônicos e Gestão de Projetos. Também contata-se que a maioria opta por Cursos de Especialização ou Extensão para a busca de capacitação na área desejada. O que talvez explique isso é o crescimento acelerado das tecnologias e mudanças constantes nos ramos do negócio da empresa em que o profissional atua, fazendo com que ele opte por cursos mais rápidos, especializados e focados, para apresentarem soluções em curto prazo para a empresa. Ou o profissional, também, pura e simplesmente, não tem a disponibilidade de realizar cursos mais longos, por não ter o incentivo por parte da organização, o que não é raro ocorrer. Outra constatação também é com relação às ofertas de cursos sobre esta temática que podem não estar suprindo a demanda específica pelos Profissionais da Informação. As análises sobre tal assunto serão exploradas no item 4.2 desta pesquisa.

Outra constatação que pode parecer contraditória - diante das respostas deste questionário - é que, mesmo tendo realizado todos esses cursos, sendo alguns deles voltados somente para a Qualidade, o profissional atuante, pouco desenvolve ou utiliza estas técnicas e ferramentas específicas. Isto pode ser um indicador de que o profissional, objeto desta pesquisa, ainda não se considera suficientemente apto a gerir com vistas à Qualidade seu Centro de Informação.

\subsubsection{Disponibilidades para a educação continuada}

Nesta questão, o intuito foi verificar se o profissional teria disponibilidade e motivação para realizar cursos que o qualificassem em Gestão da Qualidade e $100 \%$ disseram que sim, ou seja, todos eles se consideram motivados em relação ao tema da pergunta e, teoricamente, com disponibilidade para tanto.

No entanto, mesmo que supostamente esses profissionais sintam-se preparados para atuar neste cenário (questão 2.5), e mesmo que anteriormente já tenham se preparado de alguma forma (questão 3.1), eles ainda possuem o interesse em realizar cursos que os qualifiquem na área da Qualidade, ou seja, 
constata-se que ainda precisam de mais segurança e conhecimento para a aplicação dessas técnicas. Assim, a próxima questão teve o objetivo de relatar as sugestões de cursos que ainda gostariam de realizar (3.3 Gostaria de realizar cursos nestas áreas? Se sim, o que gostaria que fosse enfocado nestes cursos?).

De acordo com as respostas, todos sugeriram mais de um curso, e apenas um profissional não gostaria de realizar tais cursos, pois justifica não atuar na área. Segue o elenco das sugestões dadas pelos profissionais:

1- Curso sobre Mapeamento de Processo de Negócio e Gestão de Conteúdo Empresarial;

2- Curso sobre Aprimoramento e Conhecimento do uso Sistemático de Indicadores dentro da Perspectiva de Desenvolvimento da Competência Profissional;

\section{3- Curso sobre Gestão da Informação e do Conhecimento;}

\section{4- Curso sobre Elaboração de projetos.}

De acordo com as respostas, pode-se afirmar que o profissional acredita que esses cursos deveriam estar disponíveis sempre que fosse necessário aplicar ou viabilizar projetos que visem à qualidade. Assim sendo, verifica-se uma demanda de qualificação pontual, rápida e corrente.

Com relação à próxima questão, sobre os profissionais possuírem incentivo para a educação continuada (3.4 Com relação à Educação Continuada, você tem motivação, disponibilidade ou incentivo para atualizar-se? Existe algum incentivo por parte da Empresa/Instituição (ajuda de custo, transporte, etc.)?), temos duas realidades: o incentivo pessoal e o institucional equiparado, ou seja, 3 empresas 
se interessam em patrocinar e motivar o profissional e duas pessoas possuem somente o incentivo pessoal.

Seguem algumas transcrições importantes para que se possa tirar algumas conclusões acerca desta questão:

Tenho motivação advinda do desenvolvimento do meu próprio trabalho e da necessidade de reflexão. Quanto às demais questões levantadas, hoje, a instituição em que atuo procura incentivar a educação continuada, mas é um local em que a alta direção (a Presidência) pode mudar anualmente $e$ as prioridades também.

Sim, a empresa investe na capacitação dos profissionais. Dispomos de todos os recursos.

Tenho motivação, disponibilidade e incentivo da empresa para realizar cursos; a dificuldade é não termos cursos práticos na área de gestão da informação e do conhecimento na cidade de Campinas, apesar de termos duas universidades bastante consolidadas. Os cursos disponíveis que atenda(sic) o mercado empresarial são sempre em São Paulo, Rio de Janeiro ou Belo Horizonte. Precisamos de cursos de pós-graduação nessa área em Campinas.

Sim, penso que é vital para o profissional da informação a atualização constante. A empresa incentiva essa prática.

É mais um incentivo de ordem pessoal que institucional, no caso de capacitação nas áreas de Ciência da Informação e Biblioteconomia. Para as áreas de Marketing/Administração a instituição oferece alguns meios e incentiva o upgrade. No momento, estou finalizando meu Mestrado em Ciência da Informação, mas a empresa já manifesta interesse que as próximas capacitações sejam mais voltadas ao Marketing.

Conclui-se, no caso desses profissionais, que a busca pela qualificação se dá mediante as prioridades da empresa dentro de um determinado momento e isso quando há o incentivo por parte da empresa. Dessa forma, percebe-se que a capacitação pontual na área da Qualidade começa a ser destacada e incentivada. 


\subsubsection{Competências para atuar no Serviço de Informação neste novo cenário e a Gestão da Qualidade.}

Depois de identificadas a importância e mostrados os exemplos de educação continuada para o profissional da informação que atua com a Gestão da Qualidade em Serviços de Informação, o objetivo desta questão foi identificar as competências que o Profissional da Informação considera primordiais para se trabalhar neste novo cenário, tentando trazê-las para a área da Qualidade. Esta foi uma maneira de verificar junto aos profissionais que a busca pela qualificação vem ao encontro do desenvolvimento dessas competências, sejam elas técnicas ou pessoais.

A relação das competências citadas do documento da SLA (2003) foi a base dos estudos desta pesquisa. Elas estão divididas em competências técnicas e competências pessoais que foram avaliadas pelo próprio profissional atuante. Desta forma, pôde-se, com isso, traçar um perfil do profissional que atuará na área de Gestão a Qualidade em Serviços de Informação.

Os profissionais escolheram as competências que achavam mais importantes por ordem de prioridade 'grau 1 e grau 2'. Assim sendo, foi possível dividir as competências em dois grupos, depois da avaliação: grupo 1, em que se contemplam as consideradas mais importantes pelos profissionais; e grupo 2 , relacionados no grau de prioridade 2 .

\subsubsection{Competências Técnicas}

No geral, as competências técnicas da SLA (2003) selecionadas pelos profissionais seguem as tendências de perfil do profissional com vista ao mercado emergente, ou seja, aquele que atua em Serviços de Informação de empresas. Assim, seguem, nos quadros 6 e 7 , as competências indicadas pelos participantes da pesquisa com grau de prioridade 1 e 2 , respectivamente. 


\section{Quadro 6: Relação das competências técnicas com grau de prioridade 1}

\section{$1^{\circ}$ Grupo: competências com grau de prioridade 1}

- conhecimento especializado do conteúdo dos Recursos de Informação existentes na Biblioteca, incluindo a habilidade de avaliá-los criticamente e filtrá-los;

- habilidade de desenvolver e administrar Serviços de Informação convenientes, acessíveis e de baixo custo que estejam alinhados com as orientações estratégicas da organização;

- habilidade para levantar necessidades de Informação, desenvolver e vender serviços e produtos de Informação com alto valor agregado, atendendo às necessidades identificadas;

- saber aprimorar continuamente os Serviços de Informação em resposta às mudanças nas necessidades.

\section{Quadro 7: Relação das competências técnicas com grau de prioridade 2}

\section{$2^{\circ}$ Grupo: competências com grau de prioridade 2}

- ser um membro efetivo da alta gerência e atuar como consultor em questões de Informação dentro da organização;

- saber usar a Tecnologia da Informação para adquirir, organizar e disseminar Informação;

- conhecimento especializado dos assuntos de interesse da organização onde esse profissional atua;

- saber desenvolver produtos de informação específicos para uso interno ou externo à organização ou para clientes individuais;

- saber avaliar os resultados do uso da Informação e conduzir pesquisa voltada para a solução de problemas de gestão de informação;

- habilidade para oferecer excelente treinamento e apoio aos usuários dos Serviços de Informação existentes na organização;

- saber usar abordagens apropriadas de negócios e de marketing para comunicar a importância dos serviços de informação para a cúpula administrativa da organização; 
Diante dessas competências técnicas avaliadas pelo profissional, tem-se algumas (negrito) que, para que sejam desenvolvidas, o profissional tem que ter capacitação voltada também para a Gestão da Qualidade.

A habilidade de desenvolver, administrar e aprimorar um Serviço de Informação, por exemplo, competência considerada a mais importante dentre todas as outras, mostra, implicitamente, que o profissional precisa também conhecer como administrar, como aprimorar esses serviços; portanto, cabe aqui também a competência em Gestão da Qualidade.

Por sua vez, a competência relacionada ao fato de saber avaliar os resultados do uso da Informação, também remete ao conhecimento de metodologias específicas de uso e avaliação de serviços aplicados à Gestão da Qualidade.

\subsubsection{Competências Pessoais}

As competências pessoais da SLA (2003) também foram avaliadas pelos profissionais, do mesmo modo como foram as competências técnicas, por meio de grau de prioridade 1 e 2 . Assim, seguem os grupos das mais importantes detectadas pelo profissional atuante: 
Quadro 8: Relação das competências pessoais com grau de prioridade 1 $1^{\circ}$ Grupo: competências pessoais com grau de prioridade 1

- $\quad$ buscar desafios e visualizar novas oportunidades dentro e fora da organização;

- comprometer-se com a excelência no desempenho de suas atividades profissionais;

- criar um ambiente de respeito mútuo e confiança;

- trabalhar bem em equipe;

- exercer liderança;

- comprometer-se a aprender durante toda a vida e a planejar a carreira pessoal;

- ter habilidades efetivas de comunicação;

- $\quad$ planejar, priorizar e focar os pontos críticos;

Quadro 9: Relação das competências pessoais com grau de prioridade 2

\section{$2^{\circ}$ Grupo: competências pessoais com grau de prioridade 2}

- $\quad$ ter uma visão geral e abrangente da organização;

- $\quad$ ser flexível e otimista em tempos de mudanças constantes;

- buscar parcerias e alianças;

- ter habilidade pessoal para negócios e saber criar novas oportunidades;

- reconhecer o valor das redes de contato pessoal e profissional;

Diante das competências pessoais identificadas e analisadas pelo profissional, verifica-se que todas - independente do grau de prioridade dado pelo profissional respondente - são extremamente importantes para a atuação plena do profissional. Porém, algumas, escolhidas pelo profissional como grau de prioridade 1, têm melhor relação com as ações que visam a busca constante pela qualidade, como: comprometer-se com a excelência no desempenho de suas atividades profissionais; planejar, priorizar e focar os pontos críticos.

Foi possível, por meio destas análises, delinear o profissional que atua em Serviços de Informação com vista a projetos voltados para a Qualidade, 
identificando seu nível de conhecimento acerca de técnicas e programas da área da Gestão da Qualidade e sua ânsia pela educação continuada. Da mesma forma, pôde-se traçar um perfil básico da competência almejada para a atuação deste profissional por meio da seleção das competências técnicas e pessoais, prédeterminadas pela SLA e analisadas pelo profissional respondente, com o qual se constata que, dentre tais competências, tem-se aquelas relacionadas especificamente com o trabalho no desenvolvimento das técnicas em Gestão da Qualidade nos Serviços de Informação.

Vale a pena destacar aqui algumas barreiras que dificultam a implantação ou o trabalho com a Gestão da Qualidade, segundo Vergueiro (1996, apud Barbêdo 2006) e Barbêdo e Turrioni (2003 apud Barbêdo 2006):

- Pouca consciência da força de trabalho das Bibliotecas sobre a necessidade de melhorar a qualidade;

- Atualização contínua e treinamentos;

- Auto-valorização do Bibliotecário;

- Falta de envolvimento do pessoal e de recursos humanos qualificados;

- Melhor compreensão das técnicas de gestão e definição do processo;

- Mudanças de hábitos e atitudes dos profissionais e funcionários;

- Pouco conhecimento de sistemas de Gestão da Qualidade.

Constata-se com isso que as maiores barreiras estão voltadas para a capacitação e qualificação profissional nesta área. Portanto, diante disso, o próximo item desta pesquisa visa complementar esta análise por meio do relato das formas de busca por qualificação, bem como mapear as ofertas de educação continuada para este profissional no desenvolvimento das competências para se trabalhar na área da Qualidade. 


\subsection{Pesquisa sobre as ofertas de educação continuada e cursos de Pós- graduação na área da Qualidade}

\subsubsection{Educação continuada: sites e portais}

Neste capítulo, temos o desenvolvimento de um dos objetivos desta pesquisa que foi "identificar a oferta de educação continuada na área de Gestão da Qualidade em Serviços de Informação", concretizado por meio de levantamento realizado com a ferramenta de busca Google, no mês de maio de 2006, sobre a temática da Qualidade, ou, mais especificamente, sobre ferramentas que visam a capacitar o profissional na área em questão e afins. Para tanto, foram utilizados os termos de pesquisa a seguir: "Cursos" +"Gestão da Qualidade"; "Profissional da Informação"+ "Serviços de Informação" + "Gestão da Qualidade Total".

Considerou-se, como forma de capacitação, tudo aquilo que fosse útil para o conhecimento profissional, e que fossem possíveis de serem mapeados por meio da web, pois sabe-se ser esta uma das formas de busca pela educação continuada que faz parte do cotidiano do profissional. Assim, pode-se encontrar e exemplificar portais relacionados à qualidade, bem como sites sobre consultorias, cursos, treinamentos. Esta análise também inclui estudo das ementas dos cursos de Pós-graduação, lato e stricto-sensu na área da Ciência da Informação e afins.

A seguir, relata-se alguns dos resultados da pesquisa feita na web: 


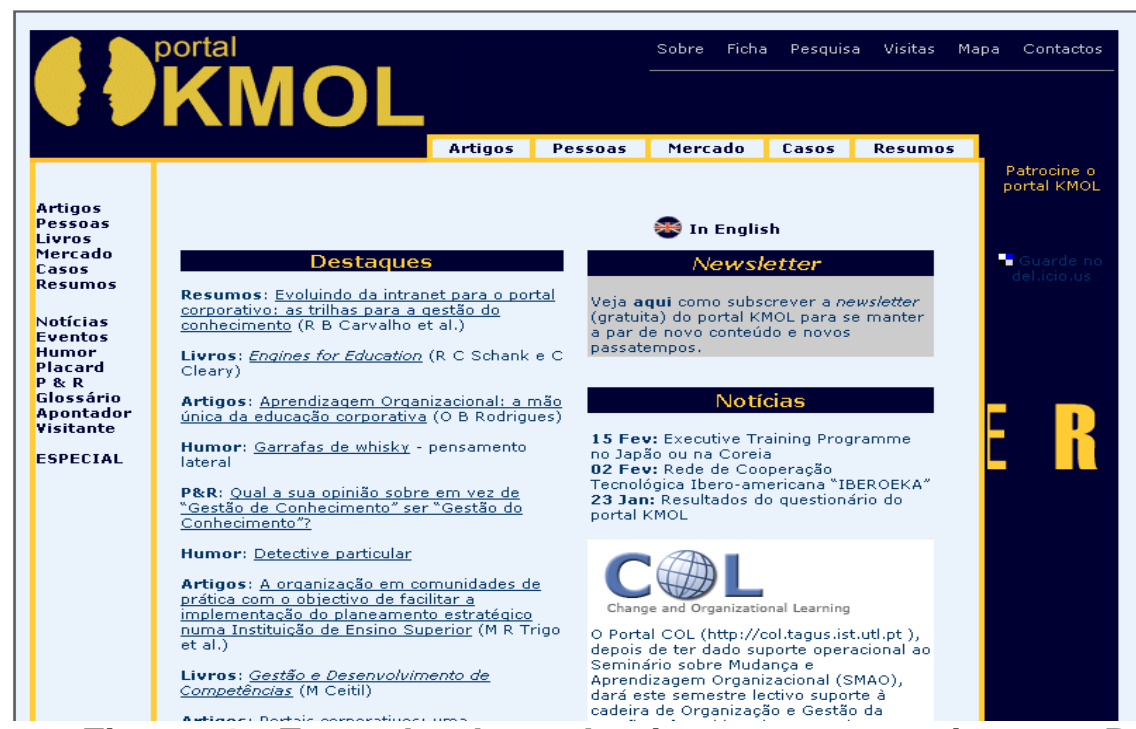

Figura 1: Exemplo de web site que caracteriza um Portal relacionado à Gestão do Conhecimento e da Qualidade (Disponível em: www.kmol.online.pt/ . Acesso em: 22/02/2007)

A figura 1 é um exemplo de portal que traz em seu conteúdo artigos, eventos, novidades, indicações de livros, crônicas, soluções e sistemas de Gestão, também relacionados à Gestão da Qualidade, Qualidade Total, Gestão do Conhecimento, liderança, motivação e aprendizagem organizacional. Pode-se dizer que é uma interessante ferramenta a qual o profissional pode vir a recorrer.

Outros exemplos de web sites (quadro 10 e figuras 2 e 3) são os que oferecem serviços de consultoria na área de Gestão da Qualidade em todos os setores de Informação que ofertam serviços que podem ser terceirizados e contratados. Também oferecem serviços de certificação e indicação de cursos. 
Quadro 10: Consultorias relacionadas à Qualidade

\begin{tabular}{|l|}
\hline CONSULTORIAS \\
\hline www.ogerente.com.br \\
\hline www.tesetreinamento.com.br \\
\hline www.setecnet.com.br \\
\hline http://qualidade.triang.com.br \\
\hline http://www.qualitivity.com.br \\
\hline http://www.jaymegusmao.com.br \\
\hline http://www.nortia.com.br \\
\hline http://scfqualidade.homestead.com \\
\hline http://www.dpss.com.br \\
\hline http://www.control.com.br/ \\
\hline
\end{tabular}

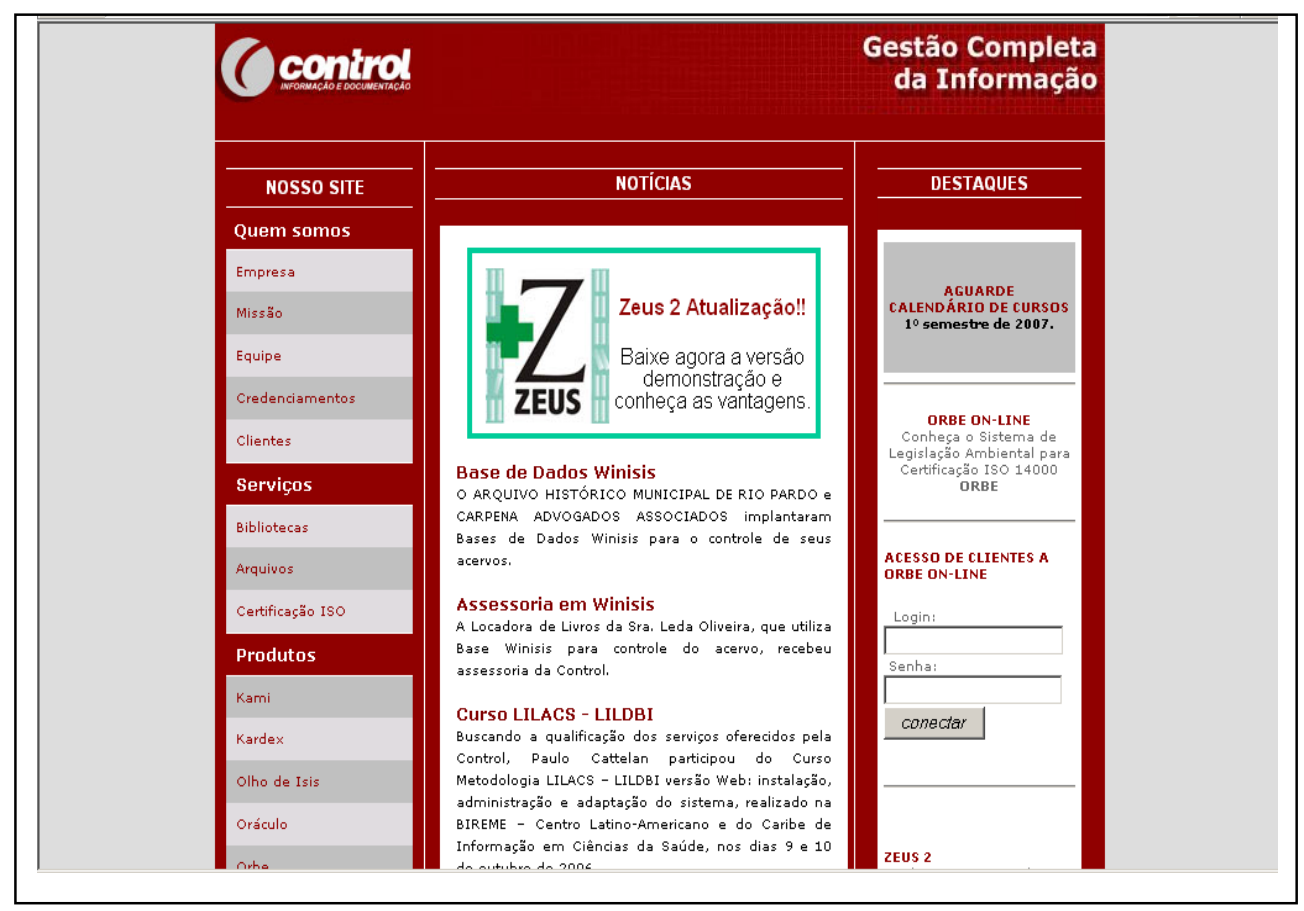

Figura 2: Exemplo de web site que caracteriza serviço de Consultoria relacionado à Qualidade (Disponível em: http://www.control.com.br/ . Acesso em: 22/02/2007) 




Figura 3: Exemplo de web site que caracteriza cursos e treinamentos relacionados à Qualidade (Disponível em: www.girus.com.br/cursos/extens.php . Acesso em: 22/02/2007)

Quadro 11: Cursos e treinamentos relacionados à Qualidade

\begin{tabular}{|l|}
\hline CURSOS E TREINAMENTOS \\
\hline www.testmat.com.br \\
\hline www.visaoeacao.com.br \\
\hline www.sommaonline.com.br \\
\hline www.cathocursos.com.br \\
\hline www.focusbusiness.com.br \\
\hline http://www.urbi.com.br/users/machadoj \\
\hline www.allsul.com.br/all/credenciados/cursos.htm \\
\hline www.sebraesp.com.br/topo/produtos/ \\
capacitação/intermediário/igestaoqualidade.aspx \\
\hline www.faccat.br/noti_20050309_03.html \\
\hline www.formedia.pt/angola/index.htm \\
\hline www.etapa.com.br/cursos \\
\hline www.5a.com.br \\
\hline www.banasqualidade.com.br \\
\hline $\begin{array}{l}\text { www.micropower.com.br } \\
\text { www.girus.com.br/cursos/extens.php }\end{array}$ \\
\hline \hline
\end{tabular}


Os exemplos relatados no quadro 11 , de sites da web sobre cursos que ofertam treinamentos rápidos relacionados à Gestão ou às técnicas da Qualidade, na maioria deles, são cursos contratados sem conteúdo especificamente sobre Gestão da Qualidade em Unidades ou Serviços de Informação.

Pode-se perceber que estas buscas e os resultados de pesquisa via web são importantes fontes de consulta para profissionais que queiram se atualizar e estar atentos às novidades relacionadas ao assunto em questão. A fonte eletrônica é considerada também uma forma de aprendizagem contínua. Assim, pode-se concluir que iniciativas são lançadas e que, se houver pesquisa adequada, o Profissional da Informação conseguirá encontrar ou, ao menos, se situar com relação à ações que poderão ser tomadas visando sua educação continuada.

Diante desta pesquisa via web, visualizou-se a existência de uma forma para a busca de capacitação para o aprimoramento das práticas e conhecimentos da Gestão da Qualidade, foco deste trabalho. Mas será que o Profissional da Informação faz uso dessas ferramentas?

Parte-se agora para outra etapa da pesquisa relacionada às ofertas de educação continuada, cuja análise deu-se através dos Cursos lato e stricto-sensu relacionados à Gestão da Qualidade. 


\subsubsection{Ciência da Informação: Cursos Lato-sensu e Stricto-sensu e a Gestão da Qualidade}

\subsubsection{Cursos Stricto-sensu}

Contemplando um dos objetivos desta pesquisa, buscou-se a relação de todos os cursos de Pós-graduação da área da Ciência da Informação no Brasil, totalizando nove (9), que foram analisados sob o ponto de vista deste estudo, ou seja, o de verificar a existência de tópicos relacionados à Gestão da Qualidade.

Desta forma, foi verificado se os Cursos de Pós-graduação, em algum momento, contemplam estudos sobre a Gestão da Qualidade em sua ementa, linhas de pesquisa, ou disciplina e tais informações foram relacionadas por meio de quadros. Também buscou-se analisar a existência de áreas afins, em que a Gestão da Qualidade possa à vir ser tratada, mas que não estão explícitas nas ementas dessas áreas.

Salienta-se que todas as informações deste Capítulo são baseadas somente na pesquisa de observação feita por meio das home-pages Institucionais e na página da ANCIB (Associação Nacional de Pesquisa e Pós-graduação em Ciência da Informação) e todos os programas comentados estão relacionados no Anexo 2 desta pesquisa. 
Quadro 12: Universidade Federal de Santa Catarina - Programa de Pós-graduação em Ciência da Informação

\begin{tabular}{l}
\hline Área de Concentração: Gestão da Informação Nível: Mestrado Início: 2003 \\
\hline Linha de Pesquisa: Fluxos de Informação \\
\hline Objetivos: Estudar os canais de produção, distribuição e circulação da informação, os \\
processos e suportes informacionais e a apropriação da informação nas unidades de \\
informação, visando construir suportes teóricos para a compreensão do funcionamento \\
das unidades de informação e para o entendimento da dinâmica dos fluxos de \\
informação na sociedade contemporânea.
\end{tabular}

A linha Fluxos de informação inclui estudos e investigações que abrangem:

- a informação no processo decisório das organizações;

- a mediação da informação(científica, organizacional, técnica,etc.);

- $\quad$ as fontes de informação;

- a gestão de processos e serviços informacionais;

- a gestão de qualidade nas unidades de informação;

- as tecnologias da informação;

- as redes de informação;

- os usuários da informação.

O quadro 12 se refere ao Curso de Pós-graduação em Ciência da Informação da Universidade Federal de Santa Catarina que contempla, na área de concentração "Gestão da Informação" e linha de pesquisa "Fluxos de Informação", um tópico de estudo e investigação que diz respeito à Gestão de Qualidade nas Unidades de Informação (grifo quadro 12). Considera-se importante ressaltar que, na maioria das vezes, os estudos sobre Qualidade em Serviços de Informação estarão atrelados às linhas de pesquisa e áreas de concentração referentes à Gestão da Informação ou Gestão de Serviços Informacionais; isto porque o conceito de Gestão da Informação, segundo Dias e Belluzzo (2003), tem seu enfoque voltado para princípios, métodos e técnicas relacionados às práticas administrativas. Neste sentido, a importância da Qualidade é ponto essencial para as políticas de Gestão da Informação (DIAS e BELLUZZO, 2003). 
O objetivo do programa de Pós-graduação da UFSC é estudar a Unidade de Informação e as dinâmicas do uso da Informação e seu fluxo, considerando-se relevante ressaltar tópicos que envolvem a Gestão da Qualidade, para o entendimento da validação e administração desse fluxo de Informação.

\section{Quadro 13: USP I ECA - Programa de Pós-graduação em Ciência da Informação (início deste programa em 2006)}

Área de Concentração: Cultura e Informação Início: Mestrado, 1972 Doutorado, 1980

Objetivo da área: Trata das relações que caracterizam os processos de construção e/ou re-construção do sentido e/ou do produto cultural quando a informação é transformada em conhecimento e o produto cultural, em bem cultural propondo a observação das ações necessárias, no contexto dos equipamentos culturais, para que a informação possa ser preservada e circular socialmente (coleta, seleção, organização, acesso) e a análise dos contextos culturais dentro dos quais estes processos se realizam e adquirem seu sentido social. A inserção dos estudos de informação no contexto social-cultural pretende fornecer uma leitura particular da introdução da Ciência da Informação no escopo das Ciências Sociais Aplicadas.

Linha de Pesquisa: Acesso à Informação

Disciplina: Qualidade em Serviços de Informação

Objetivo: Familiarizar os estudantes com os principais conceitos de qualidade e qualidade em serviços, bem como de sua aplicação ao contexto de serviços de informação.

A disciplina, relacionada no quadro 13 , anteriormente era ligada ao Programa de Ciências da Comunicação da Escola de Comunicação e Artes da USP. No ano de 2006, foi criado e aprovado pelos órgãos competentes da Universidade um programa específico em Ciência da Informação.

A área de concentração 'Cultura e Informação' e a linha de pesquisa 'Acesso à Informação' possuem como um de seus objetivos a pesquisa, 
concepção, planejamento, implementação e avaliação de sistemas e produtos informacionais. Assim, mais especificamente, a disciplina: "Qualidade em Serviços de Informação" contempla estudos voltados somente para a questão da Qualidade, seus conceitos e aplicações. Destaca-se aqui este ponto como um resultado satisfatório diante dos objetivos desta pesquisa, pois é mais uma Instituição que dissemina e ensina sobre tópicos da Qualidade voltados para os Serviços de Informação.

\section{Quadro 14: UNB - Programa de Pós-Graduação em Ciência da Informação e Documentação}

Area de concentração: Transferência da Informação

Início: Mestrado, 1978 e Doutorado, 1992.

Linha de Pesquisa: Gestão da Informação e do Conhecimento

Objetivo: Estudos teóricos, metodológicos e práticos sobre a gestão da informação e do conhecimento em sistemas de informação, bibliotecas, arquivos e demais unidades de informação sobre formação e mercado de trabalho dos profissionais da informação.

Disciplina: Planejamento e Gerência de Unidade de Informação

\section{Bibliografia:}

ABREU, R.C. Círculos de controle da qualidade. Rio de Janeiro: Qualitymark, 1991.

BELLUZO, Regina Célia Baptista e Macedo, Neusa Dias de. A gestão da qualidade em serviços de informação: contribuição para uma base teórica. Ciência da Informação, Brasília, v.22, n.2, p.124-132, maio/ago. 1993.

ISO 9004 - Gestão da Qualidade e Elementos de Sistema da Qualidade. Parte 2 JURAN, J.M. A qualidade desde o projeto; novos passos para o planejamento de qualidade em produtos e serviços. Trad.Nivaldo Montigelli Jr. São Paulo: Livraria Pioneira, 1993.

LINS, Bernardo F.E. Ferramentas básicas da qualidade. Ciência da Informação, Brasília, v.22, n.2; p.153-161, maio/ago.1993.

PARAWTHAMAN, D. Controle de qualidades. São Paulo: McGraw Hill, 1990.

PEIXOTO, Paulo. Gestão estratégica de recursos humanos para a qualidade e produtividade. Rio de Janeiro: Qualitymark,1995.

SCHOLTES, Peter R. Times da qualidade; como usar equipes para melhorar a qualidade. Trad. de Elenice Mazzilli; Lucia Faria Silva. Rio de Janeiro: Qualitymark, 1992.

SMITH, Gerald F. The meaning of quality. Total Quality Management, v.4, n.3, p.235-244, 1993. WALTON, M. O método Deming de Administração. Rio de Janeiro: Marques-Saraiva, 1983. WHITEHALL, Tom. Quality in library and Information Service: a review. Library Management, v.13, n.5, p.23-35, 1992. 
Na Universidade Federal de Brasília (quadro 14), há o programa de Pósgraduação em Ciência da Informação, que possui a disciplina "Planejamento e gerência em Unidades de Informação", área de concentração "Transferência da Informação", que contempla, em sua bibliografia básica, literaturas sobre Qualidade e Qualidade em Serviços de Informação, o que demonstra que o curso tem interesse -- não explícito -- na formação para a Qualidade.

Apresentou-se os Cursos de Pós-graduação Stricto-sensu da área da Ciência da Informação que possuem, explicitamente, em sua ementa ou disciplinas, a temática relevante desta pesquisa. Assim, pode-se verificar que somente 3 cursos de Pós-graduação levam o profissional a refletir sobre o assunto 'qualidade'. No entanto, vale ressaltar que existem também programas de Pósgraduação específicos em Qualidade ou Qualidade Total, ou ISO 9000, na área da Administração. Pôde-se detectar, na pesquisa de campo, que o profissional advindo da área de Ciência da Informação também recorre a estes cursos como forma de capacitação.

\subsubsection{Cursos Lato-sensu em Qualidade voltados para Serviços de Informação}

Apresenta-se a seguir, a relação dos cursos de Pós-graduação Lato-sensu voltados para a Gestão da Qualidade em Serviços de Informação, ou seja, os Cursos de Especialização que possuem conteúdo - ora totalmente ora em parte voltados para a Qualidade. Verificou-se que esses tipos de curso são os mais procurados por profissionais atuantes em Centros de Informação em organizações, como visto e identificado na pesquisa de campo deste trabalho. 


\section{Quadro 15: Faculdade de Sociologia e Política de São Paulo IFESP - Curso de} Especialização "Gerência de Sistemas e Serviço de Informação"

Objetivos: Desenvolver competências para o planejamento e gerenciamento estratégico, a gestão de qualidade e de conteúdo de produtos e serviços de informação. Discutir novas tecnologias para pesquisa, disponibilização, preservação e acesso de informações. Este curso também proporciona conhecimento nas áreas de inteligência competitiva e da gestão de conhecimento.

Disciplina: Gestão da Qualidade e Serviços de Informação
Implantação de sistemas de gestão de qualidade. Fundamentos e aplicabilidade da qualidade em serviços de informação.

Objetivos: Dentro do enfoque apresentado, o Curso tem como objetivo apresentar os fundamentos da Gestão da Qualidade, sua aplicação na área de serviços e especificamente a Qualidade em Serviços de Informação. Complementando a base teórica, serão apresentados também os requisitos e princípios da série de normas ISO 9000 .

Este curso, do quadro 15, iniciou suas atividades na década de 1990 e prioriza em seus objetivos a formação do profissional em Gestão da Qualidade, contando com uma disciplina específica sobre o assunto, em que são trabalhadas toda fundamentação e aplicabilidade em Serviços de Informação.

De acordo com dados institucionais, o Curso especializa nesta área em torno de 20 a 30 profissionais anualmente. Na pesquisa de campo deste trabalho, temos um profissional que se especializou nesta Instituição.

Considera-se esta uma importante fonte de capacitação profissional na área, visto que a maioria dos profissionais da pesquisa de campo prioriza a realização de Cursos de Especialização. Acredita-se que isso ocorra por tais cursos serem específicos em suas temáticas e com carga-horária reduzida quando comparada aos cursos stricto-sensu. 
Quadro 16: Universidade Central Paulista- UNICEPI São Carlos / MBA em Gestão de Unidades de Informação

Objetivos: Capacitar e atualizar profissionais para o exercício de atividades administrativas em Unidades de Informação; proporcionar uma visão gerencial associada aos recursos, serviços e produtos de Unidades de Informação e fornecer referenciais teórico-metodológicos nas áreas relativas à organização da informação e aos aspectos tecnológicos da informação.

Programa: Metodologia do Trabalho Científico. Planejamento Estratégico e

Ferramentas da Qualidade para Gestores da Informação. Administração por Projetos.

Gestão de Pessoas. Marketing para Unidades de Informação

No quadro 16 apresenta-se o curso de MBA (Master Business Administration) em Gestão de Unidades de Informação, oferecido pelo Centro Universitário Central Paulista e que está sendo ministrado na cidade de São Carlos, interior de São Paulo. Formará sua primeira turma no final do ano de 2007 e conta com um total 23 de Bibliotecários inscritos.

Tendo em vista seus objetivos, pode-se concluir que este capacita profissionais em Administração de Serviços de Informação e organização da Informação e, por conseguinte, capacita também na área da Qualidade, deixando isso explícito em seu programa. Além disso, pode ser considerado um Curso de Especialização pertinente à área de Ciência da Informação e pertinente à proposta de capacitação com vista à Gestão da Qualidade em Serviços e Unidades de Informação, haja vista a temática desenvolvida. 
Quadro 17: Centro Universitário Augusto Motta -UNISUAM / Curso de Especialização em Sistema de Informação e Qualidade Total

Carga horária: $\mathbf{4 0 0}$ horas - divididos em 4 módulos
Objetivo: Desenvolver visões estratégicas e analíticas, proporcionando aos
participantes, além do conhecimento técnico, um instrumental que lhes permita:
- estimular as pessoas que integram sua equipe a buscar novas formas de pensar e
- integrar profissionais e conhecimentos objetivando o sucesso da empresa;
- trabalhar na certificação e na implantação do Sistema de Gestão de Qualidade
Total;
- implantar, gerenciar e manter um sistema de informação eficaz em sua empresa.
Módulo - Desafios Gerenciais e de Qualidade - 135 h
Disciplinas:
- Introdução à Gestão da Qualidade Total
- Tópicos Avançados em Qualidade Total

Este curso de especialização, do quadro 17, teve início em março de 2006 e é totalmente desenvolvido para capacitar o profissional, em Gestão da Qualidade em Sistema de Informação, atuante em empresas. É oferecido pelo Centro Universitário Augusto Motta, localizado no Rio de Janeiro, e possui cerca de 60 profissionais que se formarão em 2007.

Um de seus objetivos é capacitar o profissional para a implantação de sistemas de Gestão da Qualidade Total, também o capacitando para a gerência de um Sistema de Informação na empresa. Em decorrência disto, é dividido em quatro módulos, possuindo disciplinas específicas de fundamentação da Qualidade Total, sendo este o módulo que possui maior carga horária. 


\subsubsection{Cursos Lato-sensu na área da Qualidade}

Os cursos de Especialização atingem, de maneira expressiva, os Profissionais da Informação, pois possibilitam sua capacitação nos assuntos específicos pertinentes à área e são oferecidos em carga horária reduzida, quando comparados aos Cursos Stricto-sensu. Estes aspectos também foram salientados nos resultados da pesquisa de campo. Assim, para completar este tópico, também se julgou interessante colocar alguns exemplos de cursos Lato-sensu sobre Qualidade, oferecidos fora do foco do Serviço de Informação e da área da Ciência da Informação, que são relatados nos quadros 18, 19 e 20. 


\section{Quadro 18: Universidade Estácio de Sá - SISTEMAS DE QUALIDADE E PRODUTIVIDADE - FOCO EM SISTEMAS PARA GESTÃO INTEGRADA}

\begin{tabular}{|l|}
\hline Carga horária total: 384 horas/aula $/ 59^{\circ}$. turma em 2006 \\
\hline OBJETIVOS \\
\hline - Aprofundar a percepção da moderna concepção dos sistemas integrados, suas \\
interações com a comunidade e com as noções holísticas de qualidade de vida como \\
fator de desenvolvimento e competitividade.
\end{tabular}

- Capacitar profissionais para um novo mercado em que uma crescente demanda de perfil empreendedor está focada para o trinômio: qualidade de vida, recursos renováveis, responsabilidade social, ergonomia e segurança (O Ser Humano Integral).

- Proporcionar informações para o desenvolvimento de empreendimentos próprios com a utilização da metodologia pertinente a auditorias em sistemas de qualidade e produtividade sem perder de vista a sustentabilidade.

- Possibilitar a utilização de modelos de Gerenciamento de Projetos.

Síntese Histórica dos Processos de Qualidade e Produtividade - 24 h/a síntese histórica dos processos de Qualidade. Educação e treinamento. As mudanças técnico-estruturais (Reengenharia. Benchmark. ABC, ABV e TQM). Qualidade em serviços. A gestão da mudança e as estratégias de implantação. Planejamento multifuncional de Qualidade e Produtividade. Gestão integrada, seus aspectos e tendências. Ergonomia e conforto. Análise de risco, segurança, ambiente e Responsabilidade Social.

\section{Disciplina: Ferramentas da Qualidade}

Ferramentas Básicas: Brainstorming. Votação múltipla. Técnicas de grupo nominal. Diagramas de causa e efeito. Fluxogramas. Análise de campos de força. Matriz GUT. Coleta de dados. Folha de verificação. Estratificação. Diagrama e análise de Pareto. Histograma. Box-plot. Matriz 5W - 1H. Ferramentas gerenciais: Diagrama de seta. Diagrama KJ. A matriz em "T". Pentagrama. Diagrama das relações. Diagrama de afinidades.

\section{Disciplina: Sistemas ISO - 24 h/a}

Normas série ISO 9000. Normas série ISO 14000. Modelos de Normalização e Auditoria. Normas e Procedimentos Operacionais. Estudos de caso. Modelos preconizados. Comentários sobre modelos de gestão integrada. 


\section{Quadro 19: UNICAMP - Faculdade de Engenharia Mecânica Mestrado Profissional - Gestão da Qualidade Total}

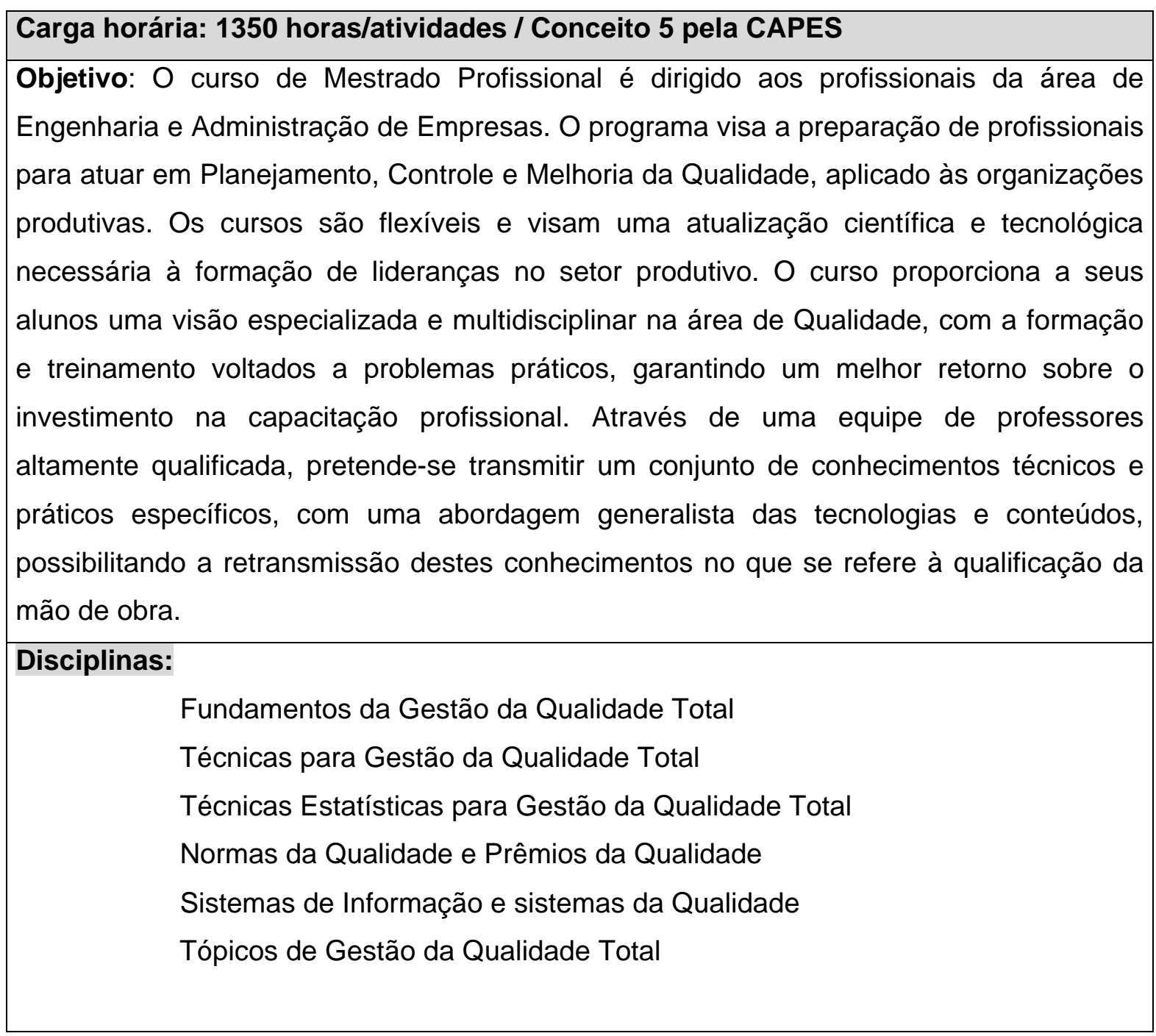


Quadro 20: INBRAPEC -Gestão e Técnicas da Qualidade

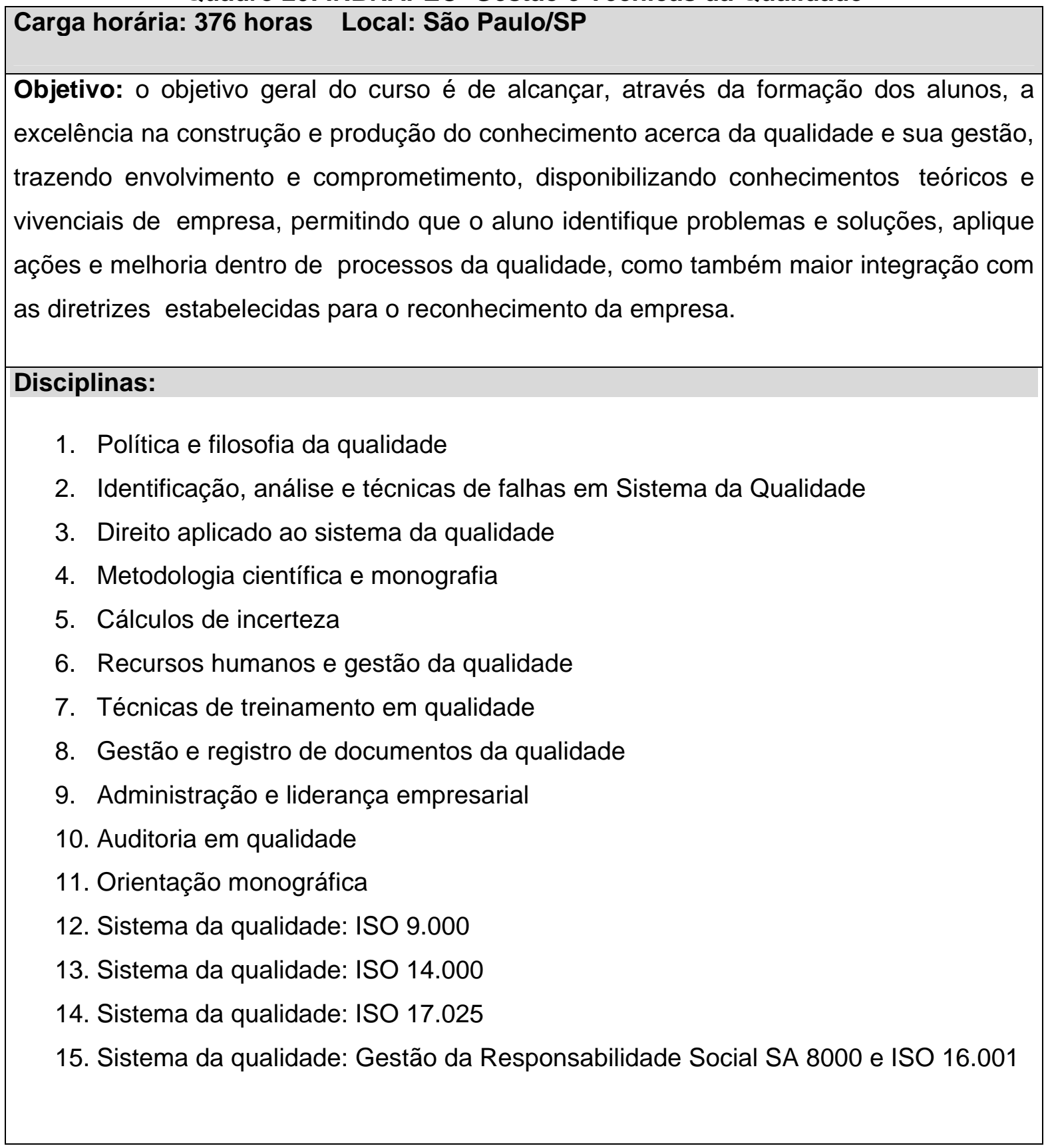


Pode-se constatar que estes são cursos que contemplam o assunto em questão, mas que estão alocados em outras áreas do conhecimento, como Administração e Engenharia Mecânica. Um é ministrado no Rio de Janeiro, capital, e os outros em Campinas e São Paulo, respectivamente.

Possuem longo tempo de existência e carga horária significativa; inclusive um deles possui em sua home-page a nota de avaliação da CAPES, isso quer dizer que, possivelmente, prezam pelo nível das atividades a que objetivam.

\subsubsection{Cursos com menos de 360 horas}

No quadro 21 tem-se três exemplos de cursos rápidos de capacitação que foram oferecidos ao Profissional da Informação nos últimos dois anos, dois no estado de São Paulo e um na cidade do Rio de Janeiro.

Estes cursos e palestras, voltados para a Gestão da Qualidade em Serviços de Informação, tiveram carga-horária de até 16 horas. Pode-se detectar também que estes cursos tiveram suas divulgações feita através da web, forma mais utilizada de divulgação da realização de cursos e palestras com carga horária reduzida. 
Quadro 21: Cursos sobre Gestão da Qualidade com menos de 360 horas Curso FEBAB (São Paulo-SP)/ Bibliotecários e Documentação da Qualidade/ ministrado em 2004 / carga horária 8 horas

Objetivo: Familiarizar os bibliotecários com o assunto Qualidade; Destacar a importância do bibliotecário no desenvolvimento de um Programa de Qualidade; Abrir perspectivas no campo profissional.

\section{Conteúdo:}

1- Conceitos Básicos Da Qualidade

1.1 Qualidade: o que é? A Norma ISO 8402.

1.2 Evolução do Conceito. Nomes famosos em Qualidade.

1.3 Importância da Qualidade em Produtos e Serviços. A competitividade.

1.4 Estudo Comparativo do Desempenho da Indústria Brasileira.

1.5 Informações sobre a série de Normas ISO 9000:2000. Evolução

2- Organização De Um Sistema De Qualidade

2.1 Abordagem sistêmica da Qualidade e suas conseqüências.

2.2 Como implementar um Programa de Qualidade Total (P.Q.T)

2.3 O início do P.Q.T. Os 5 S.

2.4 Indicadores de desempenho. O Prêmio Nacional da Qualidade.

3- A Documentação Do P.Q.T.

3.1 Definições e Tipologia.

3.2 O Manual da Qualidade.

3.3 Os demais documentos válidos como garantia do Sistema da Qualidade.

3.4 Fluxograma do Processo de Elaboração/Revisão.

4- O Papel Do Profissional Bibliotecário Na Organização E Controle Da Documentação Do P.Q.T.

Palestra/ Centro de Memória Bunge (São Paulo-SP)/ Gestão de qualidade em serviços de informação / ministrado em 2006 / carga horária 4 horas

Objetivo: apresentação de aspectos históricos e conceituais da gestão da Qualidade e sua aplicação na área de serviços, bem como análise da Qualidade em Serviços de Informação e da implantação de sistemas de Gestão da Qualidade, com seus principais benefícios e dificuldades.

Workshop MC Business I TREINAMENTO E DESENVOLVIMENTO NAS EMPRESAS (Norma NBR ISO 10015 - Gestão da Qualidade - Diretrizes para Treinamento) (Rio de Janeiro-RJ) / ministrado 09 e 10 de junho de 2006 / carga horária 16 horas 
Essas propostas de cursos podem colaborar para sanar alguns dos problemas detectados na pesquisa de campo, como por exemplo, a oferta de cursos rápidos, específicos e periódicos para o Profissional da Informação. Só resta saber se cursos com carga horária tão reduzida capacitam e qualificam o profissional para alguma área específica. Neste sentido, acredita-se que a assimilação desejável fica comprometida, tendo em vista a atuação profissional.

\subsubsection{Cursos Stricto-sensu na área da Ciência da Informação: Conteúdos voltados para a Gestão da Informação e Gestão de Serviços de Informação}

Dentre os nove cursos de Pós-graduação Stricto-sensu, existentes na área de Ciência da Informação, identificou-se e analisou-se seis cursos, nos quais o seu conteúdo não apresentava estudos sobre a Gestão da Qualidade: IBICT/UFRJ, PUC-Campinas, UFBA, UNESP-Marília, UFMG e UFPB.

O programa de Pós-graduação do IBICT/UFRJ - Instituto Brasileiro de Informação em Ciência e Tecnologia / Universidade Federal Fluminense - é o mais antigo de todos - iniciado na década de 70. Possui uma linha de pesquisa que trata da Gestão da Informação nas organizações e Informação na Gestão Estratégica. Assim, acredita-se que dentro desta linha poderiam ser contemplados tópicos voltados para a Gestão da Qualidade.

A PUC-Campinas possui um programa de Pós-graduação em Ciência da Informação, nível mestrado, iniciado em 1977, que também engloba uma linha de pesquisa na área de Gestão da Informação dentro da área de concentração em Administração da Informação. E conta com uma disciplina nesta linha que trabalha com os métodos de Gestão e aborda conceitos e escolas da Ciência da Administração e sua aplicação ao campo da Ciência da Informação. Talvez, nesta disciplina o programa possa trabalhar a temática da Gestão da Qualidade. 
A Universidade Federal da Bahia (UFBA) possui um programa de Pósgraduação em Ciência da Informação, nível mestrado, desde 1998 que contempla uma linha de pesquisa em Informação e contextos socio-econômicos; e Teoria e Gestão do Conhecimento, dentro da área de concentração Informação e Conhecimento na Sociedade Contemporânea. Ou seja, este programa trata da Gestão da Informação em ambiente organizacional, e, por conseguinte, pode tratar da Gestão da Qualidade nestes ambientes, mas não demonstra isso de forma explicita.

A Universidade Federal do Estado de São Paulo (UNESP), em seu programa de Pós-graduação em Ciência da Informação, nível mestrado iniciado em 1998, possui linhas de pesquisa em Informação e Tecnologia; e Organização da Informação e disciplina específica em Cultura Organizacional e Sistemas de Informação. Esta disciplina trata dos Sistemas de Informação e cultura organizacional em ambientes tradicionais e atualizados, podendo neste tópico incluir aspectos da Gestão da Informação e da Qualidade nestes ambientes.

A Universidade Federal de Minas Gerais, em Belo Horizonte (UFMG), possui no programa de Pós-graduação em Ciência da Informação, nível Mestrado iniciado em 1976; e doutorado - 1997 - a linha de pesquisa em Gestão da Informação. Seu curso objetiva capacitar profissionais que atuem com estudos específicos em Informação Estratégica no ambiente empresarial e também foca aspectos relacionados com a Gestão da Informação e do Conhecimento em contextos organizacionais. Dentre os tópicos da linha de pesquisa estudados há aspectos sobre estão, políticas e Serviços de Informação para negócios, mas não foca a temática sobre a Gestão da Qualidade.

O programa de Pós-graduação em Ciência da Informação da Universidade Federal da Paraíba (UFPB), nível Mestrado, também evidencia linha de pesquisa relacionada à Gestão da Informação (Ética, Gestão e Políticas de Informação), dentro da área de concentração Informação, Conhecimento e Sociedade._ 
Esta linha de pesquisa inclui estudos sobre Ética e Informação, Gestão do Conhecimento, gestão de unidade, de serviços e produtos de Informação, mas não evidencia o estudo sobre a Gestão da Qualidade nesses serviços.

Finalizando esta análise, cabe salientar o fato de que, quando da busca pelos cursos de Pós-graduação relacionados à Qualidade, somente dois cursos de Pós-graduação, especificamente na área de Ciência da Informação - um stricto e outro lato sensu - foram encontrados, relacionando na sua ementa tópicos sobre Gestão da Qualidade: o Curso de Especialização em Gerência de Sistemas e Serviços de Informação, da Fundação Escola de Sociologia e Política de São Paulo; e o Curso de Mestrado em Ciência da Informação, da Universidade Federal de Santa Catarina, área de concentração em Gestão da Informação, linha de pesquisa "Fluxo da Informação". Portanto, dentre os cursos analisados, foram destacadas as linhas de pesquisa e disciplinas que se acredita terem afinidades com o assunto sobre "Gestão da Qualidade", e nas quais o tema poderá ser comentado no curso, mas, explicitamente, esse assunto não foi encontrado na pesquisa feita em suas ementas. Justificando tal constatação, pode-se dizer que a pesquisa feita pela home-page do Curso ou pela página da ANCIB pode não evidenciar de forma objetiva a intenção e o trabalho "em sala de aula" com o tema. E considera-se que seria importante este tópico estar relacionado na ementa de todos os cursos de Pós-graduação, que possuíssem como linha de pesquisa ou área de concentração estudos voltados para a Gestão da Informação ou Gestão de Serviços de Informação. 


\subsubsection{Reflexão sobre o currículo básico dos cursos de Graduação em Ciência da Informação}

O documento do Ministério da Educação (Anexo 1), homologado em 03/01/2004 pelo Conselho Superior de Educação, relaciona a proposta das diretrizes curriculares da área da Ciência da Informação e demonstra que os objetivos curriculares do curso apresentam a temática da 'Qualidade', que aparece como um dos tópicos da disciplina "Gestão de Unidades e Serviços de Informação". Ou seja, esse é o documento no qual as escolas de Ciência da Informação devem basear seu currículo, constatando-se que esses assuntos devem ser trabalhados desde a Graduação.

Segue, no quadro, uma parte deste documento, que exemplifica a proposta das diretrizes curriculares específicas do Ministério da Educação (o documento na íntegra encontra-se no Anexo 1 desta pesquisa).

Quadro 22: Proposta de diretrizes curriculares do MEC para a área da Ciência da Informação

\section{MEC - DEPARTAMENTO DE POLÍTICAS DO ENSINO SUPERIOR}

PROPOSTA DE DIRETRIZES CURRICULARES

ÁREA: CIÊNCIA DA INFORMAÇÃO

Gestão de Unidades e Serviços de Informação: Princípios e evolução da

administração e da teoria organizacional. Funções da administração: planejamento, organização, execução, controle, mensuração e avaliação. Gestão de marketing, de recursos humanos, de recursos financeiros, de recursos físicos, de produção e de materiais. Qualidade aplicada ao contexto das unidades e serviços de informação.

Este documento demonstra que a temática sobre a Gestão da Qualidade faz parte das diretrizes curriculares do curso da Ciência da Informação sendo conteúdo básico desde a Graduação. Assim, o documento justifica a pesquisa sobre a oferta de educação continuada para o profissional da Informação, principalmente no que diz respeito à temática sobre a Gestão da Qualidade, e que 
também deve fazer parte das ementas dos programas de Pós-graduação Stricto ou Lato-sensu da área.

Concluindo, pode-se dizer que "a discussão em torno das qualificações necessárias para que o profissional da informação interaja como sujeito diante das demandas do mundo do trabalho não é recente", assim como, "a necessidade para que os cursos de formação profissional adaptem seus currículos às transformações da sociedade". (ARRUDA, 2000). Assim, percebe-se que a área de Ciência da Informação e, mais especificamente, tópicos que trabalham com a Gestão da Informação, ainda não possuem claramente a iniciativa de ter em seus conteúdos as teorias que abordam o tema da Qualidade, ou a Gestão da Qualidade em Serviços de Informação. Mas, em contrapartida, e de acordo com Valls (1998) a preocupação com a qualidade não é questão nova para os Bibliotecários. Para complementar esta afirmação, Vergueiro e Valls (2006), analisando estudos sobre o tema, perceberam que são crescentes as práticas profissionais relacionadas à temática, que possuem maior concentração nas Bibliotecas Universitárias.

A utilização de conceitos, teorias, ferramentas e certificações da Qualidade em Unidades de Informação são instauradas cada vez mais no cotidiano das Bibliotecas Universitárias, mas percebeu-se - pela literatura - pouca prática em Bibliotecas e Centros de Informação especializados de organizações e empresas. Segundo Valls (2006), a questão é contraditória, visto a grande ocorrência de certificações com base na NBR ISO 9001 nas empresas, confirmando a probabilidade de estar acontecendo o não envolvimento dos Serviços de Informação nesta questão, por falta de capacitação e envolvimento profissional e/ou a não divulgação dessas iniciativas por meio da literatura. 
5 Conclusões e Recomendações 
Esta pesquisa intentou mostrar alguns caminhos que o profissional deve trilhar na sua educação continuada para se adequar à demanda do mercado, que, atualmente, exige, que as Instituições trabalhem visando à qualidade em todos os seus setores, inclusive nos Serviços de Informação. Procurou-se traçar, também, o perfil de competências técnicas e pessoais, que podem ser desenvolvidos com vistas à Qualidade.

As organizações passam a buscar, no mercado de trabalho, profissionais capazes de gerenciar seu acervo informacional. E estes devem gerir seu Centro de Informação ou seu Serviço de Informação baseados em modelos de Gestão da Qualidade, principalmente se for considerado que muitas organizações possuem políticas para a Qualidade.

Cabe dizer que há a certeza, então, de que, dentro dessa dinâmica, é importante que as ações direcionadas à formação profissional e à educação continuada dos Profissionais da Informação estejam sedimentadas na compreensão dos processos de transformação por que passa o mundo do trabalho, e, também, nas práticas administrativas que exigem conhecimentos específicos sobre a Qualidade, seus fundamentos e aplicabilidades. Assim, o delineamento do perfil profissional vem atrelado a essas novas formas de gestão do trabalho, que envolvem a atuação em equipe, a interdisciplinaridade, o aprendizado contínuo e novas atitudes comportamentais.

Valorizando a temática sobre a formação e capacitação voltada para os princípios da Qualidade nos Serviços de Informação e validando a hipótese desta pesquisa, em que se afirma que o Profissional da Informação precisa ter capacitação adequada na área da Gestão da Qualidade para atuar no mercado emergente, conclui-se que:

- $\quad$ Por meio da pesquisa de campo, percebeu-se que o profissional tem conhecimento de que seu serviço precisa ser direcionado e 
avaliado seguindo os princípios da qualidade; assim sendo, utilizam algumas técnicas voltadas para este aspecto. No entanto, possuem pouca capacitação nessa área, voltada especificamente para o objeto em questão, o que talvez explique o mínimo de conhecimento que apresentaram sobre as ferramentas da qualidade e sua aplicabilidade.

- Os profissionais pesquisados possuem incentivo pessoal e incentivo profissional para buscar a educação continuada e a maioria externou seu interesse em realizar cursos para se capacitarem. Assim, viu-se que existe a demanda por ofertas de educação continuada em Gestão da Qualidade, mas, também, que, por parte da organização, ainda existe, talvez, o desconhecimento ou a desvalorização do Profissional da Informação neste ambiente de atuação.

- $\quad$ Pela pesquisa de busca das ofertas de capacitação, temos que as ofertas de Cursos Lato-sensu estão começando a se destacar, mas a maioria dos cursos tem menos de um ano ou até um ano de existência. É possível afirmar que os cursos com menos de 360 horas de duração não teriam aproveitamento significativo para a compreensão e fixação do conhecimento do tema proposto. Da mesma forma, os cursos de Pós-graduação Strito-sensu poderiam ter o tema "Gestão da Qualidade" melhor explorado, visto que, por meio da pesquisa, foi constatado que somente alguns cursos destacam e exploram essa temática em suas ementas.

A prática do Profissional da Informação em empresas e organizações está começando a crescer, bem como, a oferta de capacitação que busquem contemplar e subsidiar o ambiente organizacional, o que se pode considerar é que 
poderiam ser mais explorados estudos específicos na área da Gestão da Qualidade em Serviços de Informação nos programas de Pós-graduação da área, visto que a temática está diretamente atrelada à Gestão da Informação, ou seja, a prática cotidiana do Profissional da Informação em qualquer ambiente de trabalho.

Dessa forma, considerou-se que o objetivo geral e os específicos desta pesquisa foram atingidos na medida em que esta:

- identificou e analisou o nível de atuação do Profissional da Informação, Bibliotecário na área de Gestão da Qualidade em Serviços da Informação no ambiente emergente (organizações e empresas).

- identificou a oferta de educação continuada sobre Gestão da Qualidade em Serviços de Informação, em todas as suas formas, incluindo pesquisas feitas na web, por meio de portais e sites que trazem em seu conteúdo informações a respeito da temática aqui explorada, tais como: cursos, treinamentos, consultorias, artigos, debates, detectando-se assim, que são poucos os cursos de Pósgraduação da área que enfatizam o tema em suas ementas;

- identificou, diante dessas ofertas, as carências no processo de formação para e educação continuada do Profissional da Informação para a inserção no mercado, bem como as principais competências técnicas e pessoais deste profissional, baseando-se nos estudos internacionais da Special Libraries Association e pontuando as que tinham relação com a Gestão da Qualidade;

- refletiu, também, sobre a qualificação do Profissional da Informação voltado para a Gestão da Qualidade em Serviços de Informação atuantes em empresas, possibilitando entender o processo de oferta 
e demanda por qualificação e também entender o processo do aprender/fazer ou teoria/prática, no dia-a-dia destes profissionais.

Entende-se que os resultados da pesquisa de campo confirmam a demanda do profissional por capacitação na área da Qualidade e a diversidade de formas do profissional adquirir este conhecimento por meio da educação continuada, demonstrando a importância de a Ciência da Informação oferecer tal formação.

Com esta reflexão, aponta-se alguns fatos sobre a educação continuada do Profissional da Informação, tratando do tema sobre a Gestão da Qualidade em Serviços de Informação, assim, procurou-se, neste trabalho, apresentar de forma clara e sucinta o cotidiano da prática profissional voltada para a Qualidade. Nesse sentido, tratamos aqui a 'Qualidade' como componente decisivo das atividades que exigem gerir um Serviço de Informação, seja ele de qualquer ambiente. E mais, as fundamentações que envolvem esse componente devem ser trabalhadas nas fases da formação do profissional, líder deste processo de gestão.

De acordo com constatação disponível na literatura da área, conhecer a percepção do Serviço de Informação e de seus clientes sobre a Qualidade dos produtos e serviços oferecidos é vital para se implementar melhorias nas práticas vigentes. Assim, condutas visando à Qualidade, tanto nos processos de atendimento ao cliente quanto no desenvolvimento de competências técnicas ou pessoais, não só levam à efetividade na Gestão dos Serviços de Informação como trazem resultados ao ambiente organizacional.

As reflexões finais desta pesquisa vão no sentido de mostrar que a interação das transformações que englobam o homem e seu ambiente resulta em um processo contínuo de aprendizagem, em que valores são repensados a ponto de serem criadas condições que permitam o crescimento profissional, dando uma nova direção ao "Moderno Profissional da Informação"; estas condições permitem 
a aprendizagem contínua e evitam a alienação, a inércia ou até mesmo a obsolescência do profissional.

Por fim, considera-se importante ressaltar que, na formação do Profissional da Informação, a concepção de ensino e aprendizagem permite que o mesmo elabore soluções para as rotinas e os problemas enfrentados na atividade profissional. Assim, o profissional que souber unir o aprender / fazer e ser crítico e criativo diante das transformações - sejam elas sociais ou tecnológicas - saberá responder às novas exigências do mercado de trabalho. Por esse motivo, considera-se que as rotinas acerca da Gestão da Qualidade em Serviços de Informação devem aparecer na trajetória educativa e formativa do Profissional da Informação, permitindo capacitá-los, continuamente, para a produção de novos conhecimentos acerca desta prática profissional e espera-se que as reflexões aqui apresentadas possam contribuir para que a área da Ciência da Informação responda a tais necessidades. 


\section{Recomendações:}

Assim, diante dessas conclusões, recomenda-se:

\section{1) Às Entidades de Classe:}

- que instituam estudos periódicos sobre demanda de mercado do Profissional da Informação para serem definidas as ações onde estes órgãos possam intervir, como por exemplo, na valorização e divulgação da profissão, tendo em vista que a preocupação com a qualidade (dos produtos e serviços, dos processos e da gestão das organizações) tem que ser hoje uma preocupação permanente de todos (e de cada um) dos gestores e colaboradores da empresa/organização.

2) Às instituições formadoras da área da Ciência da Informação:

reformulem ou revisem as ementas dos cursos oferecidos pelos programas de Pós-graduação da área, no sentido de incluírem ou explicitarem a temática da Qualidade em suas ementas, considerada pertinente principalmente em linhas de pesquisa já existentes que tratam da Gestão ou Administração da Informação. 


\section{3) Ao Profissional da Informação, Bibliotecário e pesquisadores :}

- $\quad$ repensem suas atividades, focadas na implantação de projetos e na reestruturação de seus Serviços de Informação visando à qualidade - assim terão subsídios para certificar seus serviços, valorizando a imagem da profissão em qualquer que seja o ramo da organização.

- $\quad$ divulguem suas experiências e vivências nesta área para seus pares, pois há carência de estudos científicos ou relatos de experiências contínuos voltados para a compreensão desta temática. 
ADBS. Referentiel des métiers-types et competences des professionnels de l'information et de la documentation. Paris: ADBS, 1998.

AMBONI, Narcisa de Fátima. Qualidade em serviços: dimensões para orientação e avaliação das bibliotecas universitárias federais brasileiras. In: SEMINÁRIO NACIONAL DE BIBLIOTECAS UNIVERSITÁRIAS, 13., 2004, Natal. Anais... Natal: BCZM, 2004. 1 CD-ROM.

. Qualidade em serviços: dimensões para orientação e avaliação das bibliotecas universitárias federais brasileiras. 2002, 227 f. Tese (Doutorado em Engenharia de Produção) - Centro Tecnológico da Universidade Federal de Santa Catarina, Florianópolis, 2002.

ANDRADE, Marcos Vinícius Mendonça. Gestão da qualidade em bibliotecas universitárias: indicadores de desempenho e padrões de qualidade. 2004, 115 f. Dissertação (Mestrado em Sistemas de Gestão) - Universidade Federal Fluminense, Niterói, 2004.

ARECO, Angela Maria Barreto. Qualidade Total: a nova aspiração bibliotecária. In:CONGRESSO DE BIBLIOTECONOMIA E DOCUMENTAÇÃO E CIÊNCIA DA INFORMAÇÃO E ENCONTRO NACIONAL EM INFORMAÇÃ̃O E DOCUMENTAÇÃO JURÍDICA, 4., 1992, São Paulo. Anais... São Paulo: APB, 1992. p. 98-103.

ARANHA, F. E-service em bibliotecas: geração de valor para pesquisadores por meio de cooperação indireta. Revista de administração de empresas, São Paulo, v. 40, n. 4, p. 84-93, 2000.

ARRUDA, Maria da Conceição Calmon; MARTELETO, Regina Maria; SOUZA, Donaldo Bello. Educação, trabalho e o delineamento de novos perfis profissionais: o bibliotecário em questão. Ciência da Informação, Brasília, v. 29, n. 3, p. 14-24, set./dez. 2000.

ASSOCIAÇÃO BRASILEIRA DE NORMAS TÉCNICAS. Certificação. Disponível em: <http://www.abnt.org.br/certificacao.htm>. Acesso em: 15 maio 2006.

ASSOCIAÇÃO BRASILEIRA DE NORMAS TÉCNICAS; COMITÊ BRASILEIRO DA QUALIDADE. Certificação ISO-9000, Empresas certificadas ISO 9000, Organizações Credenciadas. Disponível em:

<http://200.20.212.34/cb25i/RetornaOCCred.asp?Chamador =CB25 $>$. Acesso em: 15 maio 2006.

ASSOCIAÇÃO BRASILEIRA DE NORMAS TÉCNICAS. NBR ISO 9000: Sistemas de gestão da qualidade - fundamentos e vocabulário. Rio de Janeiro, 2000. 
BAPTISTA, Ivani. Diagnóstico do nível de satisfação do cliente da biblioteca central da Universidade Estadual de Maringá com vistas à qualidade. In: SEMINÁRIO NACIONAL DE BIBLIOTECAS UNIVERSITÁRIAS, 11., 2000, Florianópolis. Anais... Florianópolis: UFSC, 2000. Disponível em: $<$ http://snbu.bvs.br/snbu2000/docs/pt/doc/poster014.doc>. Acesso em: 15 maio 2006.

BARBALHO, Célia Regina Simonetti. Gestão pela qualidade: referencial teórico. Transinformação, Campinas, v. 8, n. 3, p. 97-120, set./dez. 1996.

. Padrão de conformidade para Unidades de Informação: apresentação do modelo inglês. Informação \& Informação, Londrina, v. 2, n. 2, p. 47-54, jul./dez. 1997.

Qualidade \& Unidades de informação: uma parceria em busca de melhoria. 1995, 133 f. Dissertação (Mestrado em Biblioteconomia) - Faculdade de Biblioteconomia, PUC-Campinas, Campinas, 1995.

BARBÊDO, Simone Angélica Del-Ducca. Sistema de gestão da qualidade em serviços: estudo de caso em uma biblioteca universitária. 2004, $134 \mathrm{f}$. Dissertação (Mestrado em Engenharia de Produção) - UNIFEI, Itajubá, 2004. Disponível em: <http://www.ppg.efei.br/cpgp/Dissertacao/2004/89.pdf>. Acesso em 15 maio 2006.

et al. Avaliação dos serviços e identificação de oportunidades através do Desdobramento da Função Qualidade: aplicação em uma biblioteca da área de saúde. In: CONGRESSO BRASILEIRO GESTÃO DE DESENVOLVIMENTO DE PRODUTO, 4., 2003, Gramado. Disponível em: <http://www.iem.efei.br/sanches/Pesquisa/Artigos\%20publicados/a40.PDF>. Acesso em: 15 maio 2006.

BARBÊDO, S. A. D; VERGUEIRO, W. Qualidade em Bibliotecas Universitárias da Área Pública: a contribuição do GESPÚBLICA. In: SEMINÁRIO NACIONAL DE BIBLIOTECAS UNIVERSITÁRIAS, 14, 2006, Salvador. Anais... Salvador: UFBA, 2006. 1 CD-ROM.

; TURRIONI, J. B. Sistema de Gestão da Qualidade e um modelo de integração estrutural em bibliotecas: analise comparativa em dois estudos de casos. In: SIMPEP, 10, 2003, Bauru. Anais..., Bauru: UNESP, 2003. Disponível em:

<http://www.simpep.feb.unesp.br/anais10/gestaoqualidprodutividade/arq01.PDF>. Acesso em: 17 jun. 2006.

Sistemas de gestão da qualidade no setor de serviços: um estudo de aplicabilidade em bibliotecas de ensino superior de uma cidade mineira. Revista Pesquisa e Desenvolvimento Engenharia de Produção, 
Itajubá, n. 1, p. 63-76, dez. 2003b. Disponível em: <http://www.revistaped.unifei.edu.br/n1_art05.pdf>. Acesso em: 15 maio 2006.

BELLUZZO, Regina Célia Baptista. Da capacitação de recursos humanos à gestão da qualidade em bibliotecas universitárias: paradigma teórico-prático para ambiente de serviço de referência e informação, 1995. 259f. Tese (Doutorado em Comunicação). Escola de Comunicação e Artes. Universidade de São Paulo, São Paulo, 1995.

BELLUZZO, Regina Célia Baptista; MACEDO, Neusa Dias de. A gestão da qualidade em serviços de informação: contribuição para uma base teórica. Ciência da Informação, Brasília, v. 22, n. 2, p. 124-32, maio/ago. 1993.

BERAQUET, V. S. M., VALENTIM, M. L. P. Competências exigidas do profissional da informação e novas estratégias de formação. In: ENCUENTRO DE DIRECTORES, 4 e DOCENTES DE BIBLIOTECOLOGIA DEL MERCOSUR, 2, Montevidéu, Anais... Montevidéu, 2000, 11 p.

BHOPHY, P.; COULLING, Kate. Quality managemet for information and library managers. AslibGower, 1996.

BOEKHORST, P. Measuring quality: the IFLA guidelines for performance measurement in academic libraries. IFLA Journal, v. 21, n. A, 1995.

BONETTI, T. M.; MACHADO, C. S. A gestão da qualidade aplicada às bibliotecas universitárias da Universidade do Sul de Santa Catarina - princípios e implementações. In: CONGRESSO DE BIBLIOTECONOMIA E DOCUMENTAÇÃO E CIÊNCIA DA INFORMAÇÃO, 21, 2005, Curitiba. Anais... Curitiba: FEBAB, 2005. 1 CD-ROM.

BOTELHO, T. M. G.; CORTE, A . R. O mercado de trabalho do profissional da informação na área de biblioteconomia na região Centro-Oeste. Revista de Biblioteconomia de Brasília, Brasília, v. 15, n. 2, jul./dez., 1987. p. 249-284.

CARDOSO, J. C. LUZ, A R. Os arquivos e os sistemas de gestão da qualidade. Arquivistica.net, Rio de Janeiro, v. 1, n. 1, p. 51-64, jan./jun. 2005. Disponível em:<http://www.arquivistica.net>. Acesso em: 29 fev. 2006.

CARVALHO, Kátia de. O profissional da informação: o humano multifacetado. Datagramazero, v. 3, n. 5, out. 2002. Disponível em: <http://www.datagramazero.com.br/ . Acesso em: 05 maio 2006.

CASTELLS, Manuel. A sociedade em rede. São Paulo: Paz e Terra, 1999.

CASTRO FILHO, C. M.; VERGUEIRO, W. Gestão de pessoas em bibliotecas universitárias sob a ótica das teorias da qualidade: reflexões sobre a realidade 
brasileira. In: SEMINÁRIO NACIONAL DE BIBLIOTECAS UNIVERSITÁRIAS, 13, 2004, Natal. Anais... Natal: BCZM, 2004. 1 CD-ROM.

CHEN, C. C. ; RASKIN, S.; TEBBETS, D. R. Products of graduate library and information science schools: unadapted resources? Education for Information, Amsterdam, v.2, n. 3, sept. 1984. p. 163-190.

CIANCIONE, R. B. Gerência da informação: mudanças nos perfis profissionais. Ciência da Informação, Brasília, v. 20, n. 2, 1991. p. 204-208.

CRONIN, B. The education of library-information professionals: a conflict of objectives? London: ASLIB, 1982.

CRONIN, B. STIFFLER, M.; DAY, D. The emergent market for information professionals: educational opportunities and implications. Library Trends, Chicago, v. 42, n. 2, p. 257-276, fall 1993.

CROWLEY, Bill; BRACE, Bill. A choise of future is it libraries versus information? American Libraries, v. 30, n. 4, p. 76-79, apr. 1999.

CUNHA, Miriam Vieira. O Profissional da informação e mercado de trabalho. Informação \& Sociedade. v. 10, n.1, 2000a. Disponível em: $<$ http://www.informacaoesociedade.ufpb.br/ojs2/index.php/ies/article/viewFile/347/ 269>. Acesso em: 12 dez. 2006. 5 p.

. O Profissional da informação: formação e mercado de trabalho-1 (Revisão de Literatura). Ensaios APB, n. 82, São Paulo: APB, 2000b.

. O Profissional da informação: formação e mercado de trabalho-2 (Revisão de Literatura-Abordagem funcional). Ensaios APB, n. 83, São Paulo: APB, 2000c.

. O Profissional da informação: formação e mercado de trabalho-3 (Revisão de Literatura- Abordagens Institucional e Educativa e Funções). Ensaios APB, n. 84, São Paulo: APB, 2000d.

DAVENPORT, Thomas H. Ecologia da Informação: porque só a tecnologia não basta para o sucesso na era da informação. São Paulo: Futura, 1998.

; PRUSAK, L. Conhecimento empresarial: como as organizações gerenciam o seu capital intelectual. Rio de Janeiro: Campus,1998.

DEBONS, A. et al. The information professional: survey and emerging field. New York: M. Dekker, 1981.

DELPIZZO, C. E. et al. A psicologia organizacional como facilitadora do processo de implantação do programa de gestão da qualidade da UNISUL. In: 
CONGRESSO DE BIBLIOTECONOMIA E DOCUMENTAÇÃO E CIÊNCIA DA INFORMAÇÃO, 21, 2005, Curitiba. Anais... Curitiba: FEBAB, 2005. 1 CD-ROM.

DEMING, William Edwards. Qualidade: a revolução da administração. Rio de Janeiro: Marques Saraiva, 1990. 367 p.

DIAS, M. M. K.; BELLUZO, R. C. B. Gestão da informação em ciência e tecnologia sob a ótica do cliente. Bauru: EDUSC, 2003.

DOSA, M. Education for new professional roles in the information society. Education for information, Amsterdam , v. 3, n. 3, p. 203-217, Sept. 1985.

DRUKER, P. Além da revolução da informação. HSM Management, São Paulo, n.18, p. 45-55, jan./fev. 2000.

FERREIRA, Angela de Moura. Desdobramento da qualidade em serviços: o caso da biblioteca da Escola de Engenharia da UFRGS. 1997, 171 f. Dissertação (Mestrado em Engenharia de Produção) - Universidade Federal do Rio Grande do Sul, Porto Alegre. 1997.

FERREIRA, A. B. H. Novo dicionário da língua Portuguesa. 2. ed. Rio de Janeiro: Nova fronteira, 1986.

FERREIRA, Danielle Thiago. O ambiente de qualidade em um sistema de informação e a aplicação do programa 5s. In: SEMINARIO NACIONAL DE BIBLIOTECAS UNIVERSITÁRIAS, 12., 2002, Recife. Anais... Recife: Universidade Federal de Pernambuco, 2002a.

. Profissional da informação: perfil de habilidades demandadas pelo mercado de trabalho. 2002. 182 f. Dissertação (Mestrado em Planejamento e Administração de Sistemas de Informação. Pós-graduação em Biblioteconomia e Ciência da Informação, PUC-Campinas, Campinas, 2002b.

. Profissional da informação: perfil de habilidades demandadas pelo mercado de trabalho. Ciência da Informação, Brasília, v. 32, n. 1, jan./abr. 2003.

. O profissional da informação e a gestão da qualidade em serviços de informação. In: SEMINÁRIO NACIONAL DE BIBLIOTECAS UNIVERSITÁRIAS, 14, 2006, Salvador. Anais... Salvador: UFBA, 2006. 1 CD-ROM.

; SANTOS, R. N. M. Profissional da Informação: perfil de habilidades demandadas pelo mercado. Revista de Biblioteconomia de Brasília, Brasília, v. 23-24, n. 2, 1999-2000. p. 161-172. Número especial. Publicada em julho de 2001.

FEIGENBAUM, Armand Vallin. Total Quality Control. 3. ed. Singapore: McGrawHill, 1994. 863 p. 
FID. Results of Fid's survey of the modern information professional.

Disponível em: <http:// fid.conicyt.cl:8000/mip.htm>. Acesso em: 05 maio 2006.

FIGUEIREDO, Nice Menezes de; LIMA, Regina Célia Montenegro de.

Desenvolvimento profissional e inovação tecnológicas: professional development and technological innovations. Revista da escola de biblioteconomia da UFMG, Belo Horizonte, v. 15, n. 1, p. 47-67, mar.1993.

- Metodologias inovadoras para a educação continuada de bibliotecários.

Revista de Biblioteconomia de Brasília, Brasília, v. 18, n. 1, p. 161-172, jan./jun., 1990.

. Proposta para a criação de um centro nacional de aperfeiçoamento do pessoal da informação. In: CONGRESSO BRASILEIRO DE BIBLIOTECONOMIA E DOCUMENTAÇÃO, 14, 1987, Recife. Anais... Recife, 1987.

FISCHER, L. O conceito de modelo de gestão de pessoas: modismo e realidade em gestão de recursos humanos nas empresas brasileiras. In: DUTRA, J. S. (Org.) Gestão por competências. São Paulo: Gente, 2001.

FLEURY, M. T. L. Cultura da qualidade e mudança organizacional. Revista de administração de empresas, São Paulo, v. 33, n. 2, p. 26-34, mar./abr. 1993.

FONSECA, Nadia Lobo da et al. Aplicação da metodologia de indicadores da qualidade para planejamento da gestão em bibliotecas universitárias da UERJ. In: SEMINÁRIO NACIONAL DE BIBLIOTECAS UNIVERSITÁRIAS, 13, 2004, Natal. Anais... Natal: BCZM, 2004. 1 CD-ROM.

. Desenvolvimento de indicadores de qualidade para o planejamento da gestão em unidades de informação da Rede SIRIUS - Rede de Bibliotecas UERJ. In: SEMINÁRIO NACIONAL DE BIBLIOTECAS UNIVERSITÁRIAS, 12., 2002, Recife. Anais... Recife: UFPE, 2002.

FREITAS, J. D. O papel dos gerentes no processo de implementação da Gestão da Qualidade total na administração pública no estado de Goiás. Dissertação, 2004, 99 f. (Mestrado). Faculdade de Engenharia Mecânica, Universidade Estadual de Campinas, 2004.

GIL, Antonio Carlos. Métodos e técnicas de pesquisa social. São Paulo: Atlas, 1987.

GODOY, Arilda S. Pesquisa qualitativa: tipos fundamentais. Revista de Administração de empresas, São Paulo, v. 35, n. 3, p. 20-29, maio/jun. 1995. 
GOMES, M.Y.F. et al. Perspectivas profissionais face às novas tecnologias. In: CONGRESSO BRASILEIRO DE BIBLIOTECONOMIA E DOCUMENTAÇÃO, 1996, São Luis. Anais... São Luis, 1996.

GOMES, Romeu. A análise de dados em pesquisa qualitativa. In: MINAYO, Maria Cecília de Souza (Org.). Pesquisa social: teoria, método criatividade. 7.ed. Petrópolis: Vozes, 1997. p. 67-80.

GOMES FILHO, Antônio Costa. Qualidade: momentos da verdade no serviço de atendimento aos usuários. 2001. 137 f. Dissertação (Mestrado em Biblioteconomia) - Pontifícia Universidade Católica de Campinas. Campinas, 2001.

; HONESKO, A. Qualidade e empreendedorismo em Unidades de Informação: uma proposta integrada. Guarapuava: UNICENTRO, 2004. 117 p.

. Qualidade: momentos da verdade no serviço de atendimento aos usuários. In:SEMINÁRIO NACIONAL DE BIBLIOTECAS UNIVERSITÁRIAS, 12., 2002, Recife. Anais... Recife: UFPE, 2002. 15 p.

GUIMARÃES, José Augusto Chaves. Moderno profissional da informação: elementos para sua formação no Brasil. In: Transinformação, Campinas: v. 9, n. 1, jan./abr. 1997.

GUIMARÃES, M. C. S. et al. Indicadores de desempenho de bibliotecas no campo da saúde. In: SEMINÁRIO NACIONAL DE BIBLIOTECAS UNIVERSITÁRIAS, 14, 2006, Salvador. Anais... Salvador: UFBA, 2006. 1 CD-ROM.

HARMON, G. The invisible manpower market for information scientists. 1975, Boston. ANUAL MEETING OF ASIS. Proceedings... Boston, 1975. p. 59-60.

HERNON, P. ALTMAN, E. Service quality in academic libraries. New Jersey: Ablex, 1996.

HOMMERDING, Nadia M. S. O profissional da Informação e a gestão do conhecimento nas empresas: um novo espaço para atuação, com ênfase no processo de mapeamento do conhecimento e disponibilização por meio da intranet, 2001, 210 f. Dissertação (Mestrado em Comunicação) - Escola de Comunicação e Artes, Universidade de São Paulo, São Paulo, 2001.

HUIDOBRO, E. G-M. Aportaciones de la gestion de calidad a bibliotecas y sevicios de documentación. Revista Espanhola de Documentación Cientifica, v. 18, n. 1, 1995.

IGAMI, M. P. Z. et al. O uso do SERVQUAL na verificação da qualidade dos serviços de unidades de informação: o caso da biblioteca do IPEN. In: 
SEMINÁRIO NACIONAL DE BIBLIOTECAS UNIVERSITÁRIAS, 13, 2004, Natal. Anais... Natal: BCZM, 2004. 1 CD-ROM.

ISHIKAWA, Kaoru. TQC "Total Quality Control": estratégia e administração da qualidade. São Paulo: IMC, 1986. 220 p.

KREMER, J. A Formação dos bibliotecários nos Estados Unidos.Extralibris, 2006. Disponível em:

$<$ http://academica.extralibris.info/bibliotecario/a_formacao_de_bibliotecarios_n.htm 1>. Acesso em: 06 jun. 2006.

LAPEYERE, J. Garantir lê service: l'enganement client. Paris: D'oganizations, 1998. $167 \mathrm{p}$.

LIMA, I. F. de et al. O bibliotecário na sociedade da informação e do conhecimento. In: SEMINÁRIO NACIONAL DE BIBLIOTECAS UNIVERSITÁRIAS, 14, 2006, Salvador. Anais... Salvador: UFBA, 2006. 1 CD-ROM.

LINGUANOTTO, Ana Rita Junqueira et al. Indicadores de qualidade para o serviço de referência e informação: uma proposta de aplicação às bibliotecas do SIBi/USP. In: SEMINÁRIO NACIONAL DE BIBLIOTECAS UNIVERSITÁRIAS, 11., 2000, Florianópolis. Anais... Florianópolis: UFSC, 2000. 21 p.

LONGO, R. M. J. VERGUEIRO, W. Gestão da qualidade em serviços de informação do setor público: características e dificuldades para sua implantação. Revista Digital de Biblioteconomia e Ciência da Informação, v. 1, n. 1, jul./dez 2003. Disponível em: <http://server01.bc.unicamp.br/revbib/artigos/art_4.pdf>. Acesso em: 22 out. 2006.

LOPES, M I V.; POBLACION, D. A ; VIA, S. C. O mercado de trabalho em Comunicações e Artes e os profissionais formados pela ECA nas décadas de 70 e 80. São Paulo: ECA/USP, 1992.

LUZ, Carolina da. Implantação de programas da qualidade pela cerificação ISO 9001 como diferencial competitivo para as organizações. 1986, 93 f. Dissertação (Mestrado em Engenharia de Produção) - Universidade Federal de Santa Catarina, Florianópolis, 2002.

MAIA, C. A Serviços e atividades não convencionais desenvolvidas por profissionais da informação no Distrito Federal: estudo exploratório. Revista de Biblioteconomia de Brasília, v. 14, n. 2, p. 267-286, jul./dez.1986.

MARENGO, Lúcia. A sociedade de informação e o mercado de trabalho: análise das ofertas de trabalho na grande São Paulo (1992/1994). 1995. 122 f. Dissertação (Mestrado em Biblioteconomia) - Faculdade de Biblioteconomia, Pontifícia Universidade Católica de Campinas, Campinas. 1995. 
MARTINS, Neire do Rossio et al. Avaliação da qualidade de um serviço do sistema de arquivos da Unicamp: um modelo piloto de pesquisa com os usuários. In: CONGRESSO INTERNACIONAL DE ARQUIVOS BIBLIOTECAS CENTROS DE DOCUMENTAÇÃO E MUSEUS, 1., 2002, São Paulo. Textos... São Paulo: Imprensa Oficial, 2002. p. 277-93. Disponível em:

$<$ http://www.unicamp.br/siarq/publicacoes/artigo_integrar_neire.pdf $>$. Acesso em: 15 maio 2006.

MARTINS, R. D. Perfil do bibliotecário: uma realidade brasileira. In: SEMINÁRIO NACIONAL DE BIBLIOTECAS UNIVERSITÁRIAS, 14, 2006, Salvador. Anais... Salvador: UFBA, 2006. 1 CD-ROM.

MARTINS, Valéria dos Santos Gouveia. Sistemas de informação das bibliotecas da UNICAMP: identificação e avaliação dos principais indicadores de para gestão estratégica. 2004. Dissertação (Mestrado Profissional em Gestão da Qualidade Total) Faculdade de Engenharia Mecânica, Universidade Estadual de Campinas, Campinas, 2004.

; LOTTI, Luciane Politi. Guia para implantação da norma NBR ISO 9001:2000 em Bibliotecas. In: SEMINÁRIO NACIONAL DE BIBLIOTECAS UNIVERSITÁRIAS, 13, 2004, Natal. Anais... Natal: BCZM, 2004. 1 CD-ROM.

MASON, R. What is an information professional? Journal of Education for Library and Information Science, Arlington, v. 31, n. 2, p. 122-138, fall 1990.

MATTOS, João M. A sociedade do conhecimento. Brasília: ESAF/UnB, 1982.

McGREGOR, Douglas. O lado humano da empresa. 2. ed. São Paulo: Martins Fontes, 1992. $225 \mathrm{p}$.

MEDEIROS, Ana Lígia S. et al. Qualidade e produtividade em bibliotecas: estudo de caso da Biblioteca Mário Henrique Simonsen. In: SEMINÁRIO NACIONAL DE BIBLIOTECAS UNIVERSITÁRIAS, 11., 2000, Florianópolis. Anais... Florianópolis: UFSC, 2000.

MEDEIROS, R. Educação continuada como parte da formação do profissional bibliotecário: uma ação estruturante. Revista Brasileira de Biblioteconomia e Documentação, v. 2, n. 1, jan./jun. 2006.

MIRANDA, A . The role of professionalism in curriculum development for information personnel: the case of Brazil. In: INTERNARTIONAL COLLOQUIUM ON THE HARMONIZATION OF EDUCATION AND TRAINING PROGRAMMES FOR LIBRARY AND INFORAMTION AND ARCHIVAL PERSONNEL.

Proceedings... Munchen: K.G Saur, 1989. 
MONTALLI, K. M. L. Pólos tecnológicos e bibliotecas universitárias: um novo desafio para os bibliotecários. Ciência da Informação, Brasília, v. 23, n. 2, maio/ago. 1994. p. 197-205.

MOORE, N. The emerging markets for librarians and information workers. Boston SPA: The British Library, 1987.

MOSTAFA, S. P. Philosophy of education for information: British and Brazilian SLIS. London, 1991.

; PACHECO, M. R. L. O mercado emergente da informação. Ciência da Informação, Brasília, v. 24, n. 2, maio/ago. 1994. p. 171-180.

MORETTI, A. B.; PEREIRA JUNIOR, G. Auditoria interna do sistema de gestão pela qualidade. In: SEMINÁRIO NACIONAL DE BIBLIOTECAS

UNIVERSITÁRIAS, 13, 2004, Natal. Anais... Natal: BCZM, 2004. 1 CD-ROM.

MORETTI, J. W. O total quality control de A. Feigenbaum como modelo de sistemas de Gestão da qualidade. Dissertação (Mestrado) - Faculdade de Engenharia Mecânica, Universidade de São Paulo, 2003.

MULLER, Suzana P. M. O ensino de Biblioteconomia no Brasil. Ciência da Informação, Brasília, v.14, n.1, p.3-15, jan/jun,1985.

MUELLER, Suzana Pinheiro Machado. Perfil do bibliotecário, serviços e responsabilidades na área de informação e formação profissional. Revista de Biblioteconomia de Brasília, Brasília, v. 17, n. 1, p. 63-70, jan./jul. 1989.

NEELAMEGHAN, M. A . Principes directeurs pour l'elaboration des politiques relatives a la foramtion theorique et pratique ainsi qu'au developpment du personnel des bibliotheques et de l'information. Paris: Unesco, 1978.

NEVES, Elisabete da Cruz. Profissional da informação: habilidades e competências de gestor do conhecimento. 2002. 125 f. Dissertação (Mestrado em Planejamento e Administração de Sistemas de Informação) - Programa de Pósgraduação em Biblioteconomia e Ciência da Informação, PUC-Campinas, Campinas. 2002.

; LONGO, Rose Mary Juliano. Atuação do profissional da informação na gestão do conhecimento. Revista de Biblioteconomia de Brasília, Brasília, v. 2324, n. 2, p. 161-172. 1999-2000. Número especial. Publicada em julho de 2001.

NUNES, V. V. F.; SILVA, G. F. da. Estratégias de ação para gestão da qualidade nos serviços informacionais do sistema de bibliotecas da Universidade Estadual de Feira de Santana: um estudo de caso. In: SEMINÁRIO NACIONAL DE BIBLIOTECAS UNIVERSITÁRIAS, 13, 2004, Natal. Anais... Natal: BCZM, 2004. 1 CD-ROM. 
OAKLAND, J. S. Gerenciamento da qualidade total. São Paulo: Nobel, 1994.

PALADINI, E. P. Gestão da qualidade: teoria e prática. São Paulo: Atlas, 2000.

PINHEIRO, Edna Gomes; COSTA, Maria de Fátima Oliveira. Qualidade Total em Bibliotecas Universitárias a filosofia de Deming e a Biblioteca Universitária: uma nova relação em busca da gestão da qualidade. Biblioteca Universitária, maio 2000. Disponível em: <http://www.biblioteca.ufc.br/artqualidad.html>. Acesso em 15 maio 2006.

; Macieir, M. H. L. (Des)fazendo o mito sobre liderança: traçados e limites da atuação do profissional da informação na função de lider. In: SEMINARIO NACIONAL DE BIBLIOTECAS UNIVERSITÁRIAS, 10, 1998, Fortaleza. Anais... Fortaleza: UNIFOR, 1998.. Disponível em:

<http://www.sibi.ufrj.br/snbu/snbu2002/oralpdf/94.a.pdf>. Acesso em: 3 fev. 2007.

PINTO, Virgínia Bentes. Informação: a chave para a qualidade total. Ciência da Informação, Brasília, v. 22, n. 2, p. 133-7, maio/ago. 1993.

POLKE, A M.; ARAUJO, E. M. B.; CESARINO, M. A . N. Análise do mercado do bibliotecário em Belo Horizonte. Revista da Escola de biblioteconomia da UFMG, Belo Horizonte, v. 5, n. 2, set. p. 65-77. 1986.

PORTO, Yeda da Silva. Formação continuada:a prática pedagógica recorrente. In: Marin, Alda J (Org) Educação continuada. Campinas: Papirus, 2000.

RAMOS, Maria Etelvina Madalozzo. Padrões como instrumento de avaliação da qualidade em bibliotecas universitárias. In: SEMINARIO NACIONAL DE BIBLIOTECAS UNIVERSITÁRIAS, 12., 2002, Recife. Anais... Recife: Universidade Federal de Pernambuco, 2002. Disponível em: <http://www.sibi.ufrj.br/snbu/snbu2002/oralpdf/94.a.pdf>. Acesso em: 15 maio 2006.

REBELLO, Maria Alice de França Rangel. Avaliação da qualidade dos produtos/serviços de informação: uma experiência da Biblioteca do Hospital Universitário da Universidade de São Paulo. Revista Digital de Biblioteconomia e Ciência da Informação, Campinas, v. 2, n. 1, p. 80-100, jul./dez. 2004. Disponível em: <http://server01.bc.unicamp.br/revbib/sumario. php?vol=2\&num=1\&mes=jul./dez.\& edit=3\&ano=2004>. Acesso em: 15 maio 2006.

- Implantação do programa 5S para a conquista de um ambiente de qualidade na Biblioteca do Hospital Universitário da Universidade de São Paulo. Revista Digital de Biblioteconomia e Ciência da Informação, Campinas, v. 3, n. 1, p. 165-182, jul./dez. 2005. Disponível em: 
<http://server01.bc.unicamp.br/revbib/sumario. php?vol=2\&num=1\&mes=jul./dez.\& edit=3\&ano=2004>. Acesso em: 15 maio 2006.

REIS, Margarida Maria de Oliveira; BLATTMANN, Ursula. Gestão de processos em bibliotecas. Revista Digital de Biblioteconomia e Ciência da Informação, Campinas, v. 1, n. 2, p. 1-17, jan./jun. 2004. Disponível em: <http://server01.bc.unicamp.br/revbib/artigos/art_6.pdf>. Acesso em: 15 maio 2006.

ROBREDO J. Considerações prospectivas para as próximas décadas sobre a evolução tecnológica no Brasil II. O perfil dos novos profissionais da informação. Revista de Biblioteconomia de Brasília, Brasília, v. 22, n. 3, p. 13-31, jul./dez. 1989.

et al. Tendências observadas no mercado de trabalho dos bibliotecários e técnicos da informação, nas bibliotecas especializadas do Distrito Federal e qualificações requeridas. Revista de Biblioteconomia de Brasília, Brasília, v. 12, n. 2, p.123-147, jul./dez. 1984.

ROCHA, Eliana da Conceição; GOMES, Suely Henrique de A. Gestão da qualidade em unidades de informação. Ciência da Informação, Brasília, v. 22, n. 2, p. 142-152, maio/ago.1993.

ROCHA FILHO, José Queiroz da. Qualidade total em serviços de informação: o caso da siderúrgica nacional. In: INFOIMAGEM, 1995, São Paulo. Anais... São Paulo: CENADEM,1995.

RODRIGUES, Mara E. F. Relação Ensino-Pesquisa: em discussão a formação do Profissional da Informação. Datagramazero, v. 3, n. 5, out. 2002a. Disponível em: <http://www.datagramazero.com.br/>. Acesso em: 5 maio 2006.

. A formação profissional em biblioteconomia: superando limites e construindo possibilidades". Encontros Bibli, Florianópolis, n. 13, maio 2002b. Disponível em: <http://www.encontros-bibli.ufsc.br/>. Acesso em: 3 jul. 2006.

ROZADOS, Helen Beatriz Frota. Indicadores como ferramenta para avaliação de Serviços de Informação. In: CONGRESSO BRASILEIRO DEBIBLIOTECONOMIA, DOCUMENTAÇÃO E CIÊNCIA DA INFORMAÇÃO, 21., 2005, Curitiba.

Anais...Curitiba: FEBAB, 2005a. s.n.

. Uso de indicadores na gestão de recursos de informação. Revista Digital de Biblioteconomia e Ciência da Informação, Campinas, v. 3, n. 1, p. 60-76, jul./dez. 2005b. Disponível em: <http://server01.bc.unicamp.br/seer/ojs/viewarticle.php?id=41\&layout=abstract>. Acesso em: 8 fev. 2006. 
SAAD, M. R. M. et al. A DIBD e sua trajetória na conquista do prêmio paulista de qualidade de gestão. In: SEMINÁRIO NACIONAL DE BIBLIOTECAS UNIVERSITÁRIAS, 13., 2004, Natal. Anais... Natal: BCZM, 2004. 1 CD-ROM.

SALASÁRIO, M. I. C. et al. Metodologia de implantação e avaliação da qualidade de bibliotecas universitárias especializadas através da ótica dos usuários/clientes: o caso dos 4 A. In: SEMINÁRIO NACIONAL DE BIBLIOTECAS UNIVERSITÁRIAS, 13., 2004, Natal. Anais... Natal: BCZM, 2004. 1 CD-ROM.

SAMPAIO, Maria Imaculada Cardoso et al. Avaliação continuada da qualidade dos produtos e serviços oferecidos pelo SIBI/USP. In: SEMINÁRIO NACIONAL DE BIBLIOTECAS UNIVERSITÁRIAS, 12., 2002, Recife. Anais... Recife: UFPE, 2002a. Disponível em: <http://www.sibi.ufrj.br/snbu/snbu2002/oralpdf/98.a.pdf>. Acesso em: 15 maio 2006.

.Curso à distância sobre qualidade em serviços de informação. In: SEMINÁRIO NACIONAL DE BIBLIOTECAS UNIVERSITÁRIAS, 13., 2004, Natal. Anais... Natal: BCZM, 2004a. 1 CD-ROM.

. PAQ - Programa de avaliação da qualidade de produtos e serviços de informação:uma experiência no SIBi/USP. Ciência da Informação, Brasília, v. 33, n. 1, p. 142-148, jan./abril 2004b. Disponível em:

<http://www.ibict.br/cienciadainformacao/viewarticle.php?id=93\&layout=abstract>. Acesso em: 15 maio 2006.

. Percepção do cliente em relação à qualidade dos produtos e serviços oferecidos pelo SIBI/USP. In: SEMINÁRIO NACIONAL DE BIBLIOTECAS UNIVERSITÁRIAS, 12., 2002, Recife. Anais... Recife: UFPE, 2002b. 14p. Disponível em: <http://www.sibi.ufrj.br/snbu/snbu2002/oralpdf/97.a.pdf >. Acesso em: 15 maio 2006.

SANTOS, Luciano Costa. Projeto e análise de processos de serviços: avaliação de técnicas e aplicação em uma biblioteca. 2000. 110 f. Dissertação (Mestrado em Engenharia de Produção) - Universidade Federal de Santa Catarina, Florianópolis, 2000. Disponível em:

<http://www.lgti.ufsc.br/public/luciano.pdf>. Acesso em: 15 maio 2006.

et al. Gerenciando processos de serviços em bibliotecas. Ciência da Informação, Brasília, v. 32, n. 2, maio/ago, 2003, p. 85-94. Disponível em: $<$ http://www. ibict.br/cienciadainformacao/viewarticle.php?id=155\&layout=abstra ct>. Acesso em: 15 maio 2006.

SANTOS, Jussara Pereira. O perfil do profissional bibliotecário. In: VALENTIM, Marta Lígia Pomim (Org.), DANTE, Gloria Ponjuán... [et al.]. O profissional da informação: formação, perfil e atuação profissional. São Paulo: Polis, 2000. 
SARACEVIC, T. The interdisciplinanary nature of information science. Ciência da Informação. Brasília, v. 24, n. 1, p. 36-41, jan./abr. 1995.

SENAC. Administração de recursos humanos: programa de qualidade e desenvolvimentos de RH. Bauru: SENAC, 2000.

SENGE, Peter. Além da $5^{a}$ disciplina. HSM Management, São Paulo, n. 19, p. 1822, mar./abr. 2000.

SILINGOVSCHI, Regina Rita Liberati. A "Gestão da Qualidade" na administração e organização da Unidade de Informação 4 da rede de bibliotecas UNOESTE de Presidente Prudente. UEL, 2001. Disponível em:<http://www.biblioestudantes.hpg.ig.com.br/129.doc>. Acesso em: 15 maio 2006.

SILVA, Ana Estela Codato. Gestão da Qualidade em Bibliotecas: aspectos críticos. In: SEMINÁRIO NACIONAL DE BIBLIOTECAS UNIVERSITÁRIAS, 12., 2002, Recife. Anais... Recife: UFPE, 2002. 14 p. Disponível em: <http://www.sibi.ufrj.br/snbu/snbu2002/oralpdf/12.a.pdf>. Acesso em: 15 maio 2006.

. Organização do processo de trabalho em bibliotecas. In: SEMINÁRIO NACIONAL DE BIBLIOTECAS UNIVERSITÁRIAS, 11., 2000a, Florianópolis. Anais... Florianópolis: UFSC, 2000. 11p. Disponível em: <http://snbu.bvs.br/snbu2000/docs/pt/doc/t016.doc>. Acesso em: 15 maio 2006.

SILVA, Antônio Manoel dos Santos et al. O plano de Gestão da Qualidade e sua implantação na Rede de Bibliotecas da UNESP: relato de uma experiência. São Paulo: APB, 1995. (Ensaios APB, 24).

SILVA, S. B. da. O novo contexto no qual se encontra inserido o profissional da informação. In: SEMINÁRIO NACIONAL DE BIBLIOTECAS UNIVERSITÁRIAS, 14, 2006, Salvador. Anais... Salvador: UFBA, 2006. 1 CD-ROM.

SILVA, Sueli Maria Goulart. Qualidade nas bibliotecas universitárias: a influência dos objetivos. Informação e Sociedade: Estudos. João Pessoa, v. 10, n. 1, 2000b, p. 54-69. Disponível em:

<http://www.informacaoesociedade.ufpb.br/1010003.html>. Acesso em: 15 maio 2006.

SILVA, Sueli Maria Goulart. Qualidade nas bibliotecas universitárias: a influência dos objetivos. Informação e Sociedade, v. 10, n. 1, p. 54-69, 2000.

SILVA, Z. A P. M. Educação Continuada, Caminho da Cidadania. Bauru: s.n, s.d. Disponível em: <http://www.bauru.unesp.br/fc/boletim/educon/educonci.htm>. Acesso em: 12. jul. 2006. 
SOUTO, Leonardo Fernandes (Org.). O profissional da informação em tempos de mudanças. Campinas: Alínea, 2005. 102 p.

SOUZA, C. M. de. Desenvolvimento e requalificação profissional: desafios profissionais do século XXI. Niterói: s.n., s.d. Disponível em:

<http://www.utem.cl/deptogestinfo/12. Acesso em: 29 ago. 2006.

SPECIAL LIBRARIES ASSOCIATION. Compentencies for special librarians of the $21^{\text {st }}$ century. Washington, 1996. Disponível em:

<http://www.fgv.br/dg/diti/bib/geral/htm/hpbb13.htm>. Acesso em: 25 jun. 2006.

. Compentencies for special librarians of the $21^{\text {st }}$ century. Washington, 2003. Disponível em: < http://www.sla.org/content/learn/comp2003/97comp.cfm>. Acesso em: 25 jun. 2006.

ST. CLAIR, Guy. Total quality management in information services. London: Bowker-Saur, 1996.

STONE, e. W. The growth of continuing education. Library Trends, Urbana, v. 34, n. 3, p. 489-513, winter 1986.

SUAIDEN, Emir José; ARAÚJO JÚNIOR, Rogério Henrique. Biblioteca pública e a excelência nos produtos e serviços: a técnica do benchmarking. Informação e Sociedade: Estudos, João Pessoa, v. 11, n. 1, 2001, p. 15-34. Disponível em: $<$ http://www.informacaoesociedade.ufpb.br/1110101.pdf>. Acesso em: 15 maio 2006.

TALAMO, M.F.G.M. Cursos de graduação profissionalizantes: formação e mercado de trabalho. Revista Brasileira de Biblioteconomia e Documentação, São Paulo, v. 26, n. 1/2, jan./jun. 1993.

TARAPANOFF, Kira. Perfil do profissional da informação no Brasil: diagnóstico de necessidade de treinamento e educação continuada. Brasília: IEL/DF, 1997. 134 p.

. O profissional da Informação em áreas de ciência e tecnologia:

características e tendências. Ciência da Informação, Brasília, v. 18, n. 2, p. 103119, jul/dez. 1989.

. O profissional da Informação: pensando estrategicamente. In: SIMPÓSIO BRASIL-SUL DE INFORMAÇÃO. 1996, Londrina. Anais... Londrina, 1996, v.1, p. 115-141.

TARAPANOFF, Kira; SUAIDEN, Emir; OLIVEIRA, Célia L. Funções sociais e oportunidades para profissionais da informação. Datagramazero, v. 3, n. 5, out. 2002 . Disponível em: <http://www.datagramazero.com.br/> . Acesso em: 5 maio 2006. 
VALLS, V. M. A documentação na ISO 9001: 2000. Falando de Qualidade, São Paulo, v. 12, n. 133, p. 100-105, jun. 2003.

. A Gestão da qualidade em serviços de informação com base na ISO 9000. Revista Digital de Biblioteconomia e Ciência da Informação, v.3, n.2, p. 64-83, jul./dez. 2005. Disponível em: <http://www.unicamp.br/bc>. Acesso em: 05 maio 2006.

. O enfoque por processos da NBR ISO 9001 e sua aplicação nos serviços de informação. Ciência da Informação, Brasília, v. 33, n. 2, p. 172-8, maio/ago. 2004. Disponível em:

<http://www.ibict.br/cienciadainformacao/viewarticle.php?id=303\&layout=abstract>. Acesso em: 15 maio 2006.

. O profissional da informação no sistema de qualidade nas

empresas: um novo espaço para atuação com ênfase no controle de documentos e registro da qualidade, 1998, 126 f. Dissertação (Mestrado) - Escola de Comunicação e Artes, Universidade de São Paulo, 1998.

. Gestão da qualidade em serviços de informação no Brasil:

estabelecimento de um modelo de referência baseado nas diretrizes da NBR ISO 9001. 2005, 247 f. Tese (Doutorado) - Escola de Comunicação e Artes, Universidade de São Paulo, 2005.

; VERGUEIRO, Waldomiro. A gestão da qualidade em serviços de informação no Brasil: uma nova revisão de literatura, de 1997 a 2006.

Perspectivas em ciência da informação, v.11, n.1, p.118-137, jan/abr. 2006.

; _ A gestão da qualidade em serviços de informação no Brasil: uma revisão de literatura. Perspectivas em ciência da informação, v.3, n.1, p. 47-59, jan/jun. 1998.

VALENTIM, Marta L. P. O Profissional da informação: formação, perfil e atuação profissional. São Paulo: Polis, 2000. 135 p. (Coleção palavra-chave, 11).

VANTI, Nadia. Ambiente de qualidade em uma biblioteca universitária: aplicação dos $5 \mathrm{~S}$ e de um estilo participativo de administração. Ciência da Informação, v. 28, n. 3, p. 333-339, set./dez. 1999.

VERGUEIRO, Waldomiro. Gestão da qualidade em bibliotecas públicas: o difícil caminho para as instituições brasileiras. São Paulo: APB, 1995. (Ensaios APB, n. 25).

. O olhar do cliente como fator de qualidade para a gestão de bibliotecas universitárias: estudos de caso em instituições brasileiras. In: CONGRESSO 
BRASILEIRO DE BIBLIOTECONOMIA E DOCUMENTAÇÃO, 19., 2000a, Porto Alegre. Anais... Porto Alegre: PUC-RS, 2000. Disponível em:

$<$ http://www.biblioestudantes.hpg.ig.com.br/texto_76.pdf>. Acesso em 15 maio 2006.

. Qualidade em serviços de informação. 2000, 222 f. Tese (Livre Docência) - Escola de Comunicações e Artes, Universidade de São Paulo, São Paulo, 2000b. 2002. $124 \mathrm{p}$.

Qualidade em serviços de informação. São Paulo: Arte \& Ciência,

. Qualidade em serviços de informação: o foco no cliente. São Paulo: APB, 2000c. 2 v. (Ensaios APB, n. 74-75).

. Serviços ao cliente em bibliotecas universitárias brasileiras, com estudo de caso sob o enfoque na melhoria contínua. Revista Brasileira de Biblioteconomia e Documentação, São Paulo, v. 1, n. 2, p. 48-59, 2000d (Nova Série).

; BELLUZZO, R. C. B. Indicadores de qualidade em bibliotecas universitárias em face da globalização da informação. In: CONGRESSO BRASILEIRO DE BIBLIOTECONOMIA E DOCUMENTAÇÃO, 18., 1997, São Luiz. Anais... São Luiz: APBEM/FINEP, 1997. 1 Disquete.

; CARVALHO, Telma de. Definição de indicadores de qualidade:a visão dos administradores e clientes de bibliotecas universitárias. Perspectivas em Ciência da Informação, Belo Horizonte, v. 6, n. 1, p. 27-40, jan./jun. 2001.

; I Indicadores de qualidade em bibliotecas universitárias brasileiras: o ponto de vista dos clientes. In: CONGRESSO BRASILEIRO DE BIBLIOTECONOMIA E DOCUMENTAÇÃO, 19., 2000a, Porto Alegre. Anais... Porto Alegre: PUC-RS, 2000. Disponível em:

$<$ http://www.biblioestudantes.hpg.ig.com.br/texto_55.pdf>. Acesso em: 15 maio 2006.

. Gestão da Qualidade em bibliotecas universitárias brasileiras: um enfoque na certificação. In: SEMINÁRIO NACIONAL DE BIBLIOTECAS UNIVERSITÁRIAS, 12., 2002, Recife. Anais... Recife: SNBU, 2002 a. Disponível em:

<http://www.ufpe.br/snbu/docs/142.a.pdf>. Acesso em: 15 maio 2006.

. Programas de calidad em las bibliotecas brasileñas: panoramas y perspectivas. Scire, Zaragoza, v. 9, n. 1, enero/jun. 2003, p. 75-83.

. Quality in Brazilian academic libraries: proposal of indicators from the customers'point of view. In: CAIS 2000: DIMENSIONS OF A GLOBAL INFORMATION SCIENCE. Annual Conference, 28., 2000b, Edmonton. Proceedings... Edmonton: Canadian Association for Information Science, 2000. Disponível em:<http://www.slis.ualberta.ca/cais2000/vergueiro.htm>. Acesso em: 15 maio 2006. 
VERGUEIRO, Waldomiro. Quality indicators and marketing: the convergence between the providers and the customers point of views in brazilian university libraries. In: IFLA. Education and research for marketing and quality management in libraries. Munchen: Saur, 2002b, p. 236-244.

. et al. La calidad en los servicios de información: búsqueda y definición de indicadores en bibliotecas universitarias brasileras. In: CONGRESO INTERNACIONAL DE INFORMACIÓN - INFO'99. 1999, La Habana, Cuba. Ponencias. La Habana: IDICT, 1999. 1 CD-ROM.

Proposta de metodologia para a identificação de indicadores da qualidade: aplicação em bibliotecas universitárias da área odontológica. In: SEMINÁRIO NACIONAL DE BIBLIOTECAS UNIVERSITÁRIAS, 10., 1998, Fortaleza. Anais... Fortaleza, 1998, 8 p.

VICENTINI, Regina Aparecida Blanco. Analise dos padrões e indicadores de qualidade para disponibilização das teses e dissertações na biblioteca digital da Unicamp. 2004. Dissertação (Mestrado Profissional em gestão da Qualidade Total) Faculdade de Engenharia Mecanica, - Universidade Estadual de Campinas, Campinas, 2004.

VIEIRA, A S. et al. Demanda de mercado por gerentes de recursos informacionais: um estudo preliminar. Revista da Escola de Biblioteconomia da UFMG, Belo Horizonte, v. 19, n.2, p. 296-307, set.1990.

WAH, L. Muito além de um modismo. HSM Management, São Paulo, n. 22, p. 51-64. set./out. 2000.

WALTER, Maria Tereza. Implantação da Norma ISO 9001:2000 na Biblioteca Ministro Victor Nunes Leal do Supremo Tribunal Federal. Ciência da Informação, Brasília, v. 34, n. 1, p. 104-133, jan./abr. 2005. Disponível em:

<http://www.ibict.br/cienciadainformacao/viewarticle.php?id=633\&layout=abstract>. Acesso em: 8 fev. 2006.

WASSERMAN, P.; BUNDY, M. L. A program of research into the identification of manpower requirements, the educational preparation and the utilization of manpower in the library and information professions: final report. Washington: US Department of Health, Education and Welfare, 1969.

WHITEHALL, T. Quality in library and information service: a review. Library Management, v. 13, n. 5, 1992.

XAVIER, E. F. T. Qualidade nos Serviços ao cliente: um estudo de caso em bibliotecas da área odontológica. Dissertação, 2001, 224 f. (Mestrado) - Escola de Comunicação e Artes, Universidade de São Paulo, 2001.

ZANELA, Mariluci. Melhoria da qualidade nos serviços oferecidos pela biblioteca do Centro de Estudos do Mar da Universidade Federal do Paraná. In: CONGRESSO BRASILEIRO DE BIBLIOTECONOMIA, DOCUMENTAÇÃO E CIÊNCIA DA INFORMAÇÃO, 21., 2005, Curitiba. Anais... Curitiba: FEBAB, 2005. s.n. 


\section{APÊNDICES}

APÊNDICE 1: Questionário

APÉNDICE 2: Carta de Apresentação

APÊNDICE 3: Carta de Agradecimento 


\section{APÊNDICE 1: Questionário}

Prezado Profissional,

Solicito seu apoio à pesquisa intitulada "O Profissional da Informação e a Gestão da Qualidade em Serviços de Informação: Capacitação e Mercado de Trabalho", orientada pelo Prof. Dr. Waldomiro Vergueiro, respondendo o questionário a seguir.

Agradeço-lhe, antecipadamente, a colaboração.

Danielle Thiago Ferreira

1) Parte I- Identificação

1.1 Nome:

1.2 Nome da Empresa/Organização que trabalha:

1.3Formação:

Graduação:

Pós-Graduação:

Ano:

Ano:

2) Parte II - Atuação

2.1 Quais os serviços que o Centro de Informação ou a Biblioteca, onde você atua, oferece ao usuário?

() Pesquisa bibliográfica

()Atendimento, Consulta e Empréstimo

() Pesquisa em bancos de dados, periódicos eletrônicos.

() Outros

2.2 Você avalia o grau de satisfação do usuário com os serviços prestados?

() $\mathrm{Sim}$.

() Não

2.3 Como você avalia os serviços prestados?

() Caixa de sugestões

() Questionário 
() Entrevista

() Outro.

2.2 No seu dia-a-dia, você procura trabalhar de forma a utilizar conceitos básicos visando à qualidade quando procuram os serviços de sua Biblioteca/ Centro de Informação?
() $\mathrm{Sim}$
() Não

2.3 Você já utilizou algumas dessas técnicas ou desenvolveu algum desses programas no seu dia-a-dia?

() Controle de processos e produtos

() Ferramentas qualidade

() Benchmarking

() Avaliação de desempenho

() Contato com os clientes

() Nenhuma.

2.4 Você já utilizou alguma dessas ferramentas especificas da qualidade para avaliação e diagnóstico de seu Serviço de Informação?

()Fluxograma

() Gráfico de Pareto

()Diagrama de causa e efeito

()Folha de verificação

() Histograma (diagrama de freqüência)

() Carta de controle

() Gráfico de dispersão

()Brainstorming

() Técnica nominal de grupo

() Análise do campo de forças

()Checklist

()Outros. Quais?

() Nenhum 
2.5 Você se sentiu preparado para aplicar técnicas e desenvolver projetos voltados para a Gestão da Informação ou da Qualidade quando precisou? () $\operatorname{Sim}$ () Não

2.6 Como se preparou para aplicar ou desenvolver projetos voltados para a Gestão da Informação ou da Qualidade?

() Cursos

() Treinamentos

() Palestras

() Leituras

() Pesquisa via Web

() Outro. Qual?

3) Parte III - Capacitação

3.2 Você acha que é necessário conhecimento especifico, curso ou capacitação para atuar com Gestão da Informação e Gestão da Qualidade?
() $\mathrm{Sim}$
() Não

3.1 Você já realizou algum curso/treinamento especifico para atuar com Gestão de Informação ou Qualidade?

() Sim. Quais?

() Não. Por quê?

3.3 Gostaria de realizar cursos nestas áreas? Se sim, o que gostaria que fosse enfocado nestes cursos?

() Sim. Quais?

() Não. Por quê? 
3.4 Com relação à educação continuada, você tem motivação, disponibilidade ou incentivo para atualizar-se ? Existe algum incentivo por parte da empresa/organização (ajuda de custo, transporte, etc.) ?

4) Parte IV-Competências:

4.1 Dentre as principais competências técnicas e humanisticas do Profissional da Informação para gerenciar um Centro de Informação/Biblioteca com qualidade, quais as que você considera mais importante? (dar o grau de importância qualificando-a com: $1^{\circ}, 2^{\circ}, 3^{\circ}$ ).

Competências técnicas:

( ) conhecimento especializado do conteúdo dos Recursos de Informação existentes na Biblioteca, incluindo a habilidade de avaliá-los criticamente e filtrá-los;

( ) conhecimento especializado dos assuntos de interesse da organização onde esse profissional atua;

( ) habilidade de desenvolver e administrar Serviços de Informação convenientes, acessíveis e de baixo custo que estejam alinhados com as orientações estratégicas da organização;

( ) habilidade para oferecer excelente treinamento e apoio aos usuários dos Serviços de Informação existentes na organização;

( ) habilidade para levantar necessidades de Informação, desenvolver e vender serviços e produtos de informação com alto valor agregado, atendendo às necessidades identificadas;

( ) saber usar a Tecnologia da Informação para adquirir, organizar e disseminar informação;

( ) saber usar abordagens apropriadas de negócios e de marketing para comunicar a importância dos Serviços de Informação para a cúpula administrativa da organização;

( ) saber desenvolver produtos de Informação específicos para uso interno ou externo à organização ou para clientes individuais;

( ) saber avaliar os resultados do uso da Informação e conduzir pesquisa voltada para a solução de problemas de Gestão de Informação;

( ) saber aprimorar continuamente os Serviços de Informação em resposta às mudanças de necessidades;

( ) ser um membro efetivo da alta gerência e atuar como consultor em questões de informação dentro da organização. 
Competências Pessoais:

( ) comprometer-se com a excelência no desempenho de suas atividades profissionais;

( ) buscar desafios e visualizar novas oportunidades dentro e fora da organização;

( ) ter uma visão geral e abrangente da organização;

( ) buscar parcerias e alianças;

( ) criar um ambiente de respeito mútuo e confiança;

( ) ter habilidades efetivas de comunicação;

( ) trabalhar bem em equipe;

( ) exercer liderança;

( ) planejar, priorizar e focar os pontos críticos;

( ) comprometer-se a aprender durante toda a vida e a planejar a carreira pessoal;

( ) ter habilidade pessoal para negócios e saber criar novas oportunidades;

( ) reconhecer o valor das redes de contato pessoal e profissional;

( ) ser flexível e otimista em tempos de mudanças constantes.

Agradeço a colaboração! 


\section{APÊNDICE 2: Carta de Apresentação}

Prezado Profissional,

Meu nome é Danielle Thiago Ferreira, sou doutoranda do programa de Pósgraduação em Ciência da Informação da Escola de Comunicação e Artes da USP, e, venho por meio desta, solicitar encarecidamente que o questionário em anexo seja respondido pois este faz parte de uma pesquisa, que diz respeito à minha Tese de Doutorado, intitulada "O Profissional da Informação e a Gestão da Qualidade em Serviços de Informação: Capacitação e Mercado de Trabalho", orientada pelo Prof. Dr. Waldomiro Vergueiro. Esta pesquisa enfoca a atuação e capacitação do Profissional da Informação/Bibliotecário na área de Gestão da Informação e Gestão da Qualidade em Serviços de Informação em Centros de Informação/ Bibliotecas de Organizações e Empresas, por isso recorro aos profissionais atuantes nestes ambientes para analisarmos as tendências desta área, quanto as capacitações e competências.

As respostas devem ser dadas pelo Profissional da Informação/Bibliotecário, responsável pela Biblioteca ou Centro de Informação da Empresa. Pode-se realizar comentários, além das respostas a serem dadas.

Assim, agradeço o tempo dispensado respondendo a este questionário, pois sua participação será muito importante para os objetivos aos quais se propõe este trabalho.

Por existirem prazos, peço-lhe a gentileza de enviar-me suas respostas no próprio questionário e o mais breve possivel. Qualquer dúvida ou problema, por favor, entre em contato por e-mail ou telefone.

Desde já agradeço a colaboração!

\section{Danielle Thiago Ferreira}

danif Cunicamp.br

USP-ECA-/Pós-graduação em Ciência da Informação

OXX19-32135155/91136204 


\section{APÊNDICE 3: Carta de Agradecimento}

\section{Prezado Senhor(a):}

Pela presente vimos agradecer sua resposta ao questionário. Sua valiosa colaboração permitirá uma análise criteriosa de dados para a conclusão da pesquisa.

Coloco-me, assim, à sua disposição para qualquer informação e dúvida a respeito da pesquisa e reitero os protestos de estima e consideração.

Atenciosamente,

\section{Danielle Thiago Ferreira}

danifounicamp br

USP-ECA-/Pós-graduação em Ciência da Informação

OXX19-32135155/91136204 
ANEXOS

ANEXO 1: MEC- Proposta de diretrizes curriculares - Ciência da Informação ANEXO 2: Pós-Graduação - Strictu-Senso - Ciência da Informação ANEXO 3: Pós-Graduação - Latu-Senso 


\title{
DEPARTAMENTO DE POLITICAS DO ENSINO SUPERIOR
}

\author{
PROPOSTA DE DIRETRIZES CURRICULARES
}

\author{
ÁREA: CIÊNCIA DA INFORMAÇÃO \\ CURSOS: ARQUIVOLOGIA, BIBLIOTECONOMIA, MUSEOLOGIA
}

\section{HISTÓRICO}

A Secretaria de Educação Superior do Ministério da Educação e do Desporto (SESu/MEC) designou, em março de 1998, uma Comissão de Especialistas de Ensino de Ciência da Informação, com a incumbência de elaborar diretrizes curriculares para os cursos de Arquivologia, Biblioteconomia e Museologia a serem ministrados no País.

Neste trabalho foram levadas em consideração as sugestões enviadas pelas Instituições de Ensino Superior - IES em atendimento ao Edital (SESu/MEC) $n^{\circ} 4$, de 10 de dezembro de 1997, bem como as disposições da Lei $n^{\circ} 9.131$, de 25 de novembro de 1995, da Lei nº 9.394, de 20 de dezembro de 1996, do Parecer (Câmara de Ensino Superior do Conselho Nacional de Educação/MEC) $n^{\circ} 776$, de 3 de dezembro de 1997, e da legislação privativa das três profissões. Uma versão preliminar das diretrizes da área, divulgada em setembro de 1998, recebeu criticas e contribuições das entidades representativas da Biblioteconomia, especialmente da Associação Brasileira do Ensino de Biblioteconomia e Documentação - ABEBD, da Associaçäo Nacional de Ciência da Informação e Biblioteconomia - ANCIB e do Conselho Federal de Biblioteconomia CFB, cujas propostas foram aqui incorporadas. O mesmo ocorreu com os subsídios oferecidos, posteriormente, por consultores ad hoc das áreas de Arquivologia e Museologia.

\section{JUSTIFICATIVA}

O entendimento da Ciência da Informação como campo de estudo que abarca todos os fenômenos ligados à produção, organização, difusão e utilização de informações, nas diferentes áreas do conhecimento, foi objeto das discussões iniciais da Comissão. Em que medida os três cursos esgotam campo tão abrangente? Até que ponto partilham, em condições de relativa igualdade, suas características básicas? O sentido pretensamente aglutinador da chamada Ciência da Informação daria conta das especificidades da Arquivologia, da Biblioteconomia e, em particular, da Museologia? O termo é mais controvertido do que aquele formulado por Otlet quando, ao propor Documentação como conceito aplicável a diferentes organismos (centros e serviços de bibliografia e documentação, bibliotecas, arquivos históricos, arquivos administrativos e museus), acabou por promover, sobretudo entre bibliotecários e documentalistas, uma inesperada e tensa demarcação de territórios profissionais e modalidades de formação.

Longe de oferecer respostas às inúmeras questões que povoam a literatura sobre o tema ou de alimentar o nominalismo que em grande parte a caracteriza, a Comissão admitiu a afinidade entre a Arquivologia, a Biblioteconomia e a Museologia: em primeiro lugar, a partir de seu objeto comum, a informação registrada, acatadas as respectivas formas de vê-la, processá-la e utilizá-la, 
consoante diferentes tradições e marcos teóricos; e, em segundo, como disciplinas instituidoras de ambientes de mediação entre acervos ("estoques" informacionais) e necessidades do usuário, acentuando uma ou outra extremidade da relação. Considerou também oportuno recomendar, nessa abordagem, uma real e produtiva ação multidisciplinar, como indicado no item "Tópicos de estudo". Não se trata apenas de encontrar matérias comuns, numa perspectiva de economia e racionalidade curricular, como proposto pela Organização das Nações Unidas para a Educação, Ciência e Cultura - UNESCO em 1974, em seu projeto de harmonização, mas de permitir a fertilização mútua no trato com questões cuja complexidade e amplitude são, via de regra, insuficientemente resolvidas no âmbito de uma única disciplina. O pressuposto é que o trabalho conceitual sugerido pela convivência com problemas plurifacetados resulte em desafio para as ortodoxias e em estímulo para novas pesquisas, reforçando, em lugar de dissolvê-las, as diferentes identidades profissionais em pauta.

Quaisquer que sejam as fórmulas plurais - Ciência(s) da Informação, Ciências Documentárias, Gestão da Informação, Gestão do Conhecimento, Gestão da Memória, Gestão do Patrimônio Cultural etc. - encontradas pelas IES para oferecer os cursos aqui considerados, é preciso justificar conceitualmente os mecanismos de sua articulação com a área, levando em conta a existência de um patamar que priorize a interlocução com disciplinas afins.

Fixando-se nas carreiras tradicionais, que formam o arquivista, o bibliotecário e o museólogo, a Comissão admite também outras possibilidades para as IES, dependendo do perfil institucional desejado e das demandas sociais existentes:

1) criar ênfases especificas para cada uma das carreiras, justapondo à denominação básica do profissional os termos que identifiquem as modalidades adotadas (a medida supõe, sempre que necessárias, parcerias com diferentes cursos, caso em que as carreiras aqui consideradas assumem o caráter de formação complementar a conhecimentos sedimentados em outras áreas);

2) introduzir carreiras novas que mantenham afinidade conceitual com a área;

3) propor, numa perspectiva mais radical e atenta à flexibilidade que hoje se exige do profissional, o próprio bacharelado na área, com a conseqüente transformação das carreiras tradicionais em habilitações e com o processo de verticalização deslocado para estudos pós-graduados.

\section{PERFIL DO EGRESSO}

Independentemente das parcerias, especializações e curriculos adotados, a formação do profissional supõe o desenvolvimento de habilidades específicas, a formação de espirito crítico e o domínio das práticas essenciais de produção e difusão do conhecimento na área. Só assim o egresso estará em condições de suprir demandas relativas ao seu campo de atuação, trabalhando em arquivos, bibliotecas, centros de documentação, centros de memória, museus, órgãos de gestão do patrimônio cultural e instituições congêneres como espaços onde se praticam a reflexão, a pesquisa e a produção de conhecimento.

De acordo com os projetos acadêmicos dos cursos e sua organização curricular, poderão ser acentuadas determinadas características do egresso que, sem prejuizo do desenvolvimento de competências, habilidades, atitudes e procedimentos básicos, componham perfis específicos.

\section{COMPETENNCIAS E HABILIDADES}

- Utilizar as metalinguagens pertinentes;

- Demarcar campos específicos e integrar conteúdos de áreas correlatas em uma perspectiva multidisciplinar;

- Produzir e divulgar conhecimentos; 
- Gerar produtos resultantes dos conhecimentos adquiridos;

- Desenvolver e aplicar instrumentos de trabalho adequados;

- Processar documentos, quaisquer que sejam os suportes, linguagens e formatos, de acordo com as teorias, paradigmas, métodos e técnicas da área;

- Gerenciar instituições, serviços e sistemas de documentação e informação;

- Desenvolver ações expositivas, visando a extroversão dos acervos sob sua responsabilidade;

- Desenvolver ações pedagógicas voltadas tanto para a melhoria do desempenho profissional, como para a ampliação do conhecimento em geral;

- Realizar atividades profissionais autônomas de modo a orientar, dirigir, assessorar, prestar consultoria, realizar perícias, emitir e assinar laudos técnicos e pareceres;

- Responder às demandas sociais determinadas pelas transformações tecnológicas que caracterizam o mundo contemporâneo;

- Refletir criticamente sobre sua prática profissional.

\section{ATITUDES E PROCEDIMENTOS}

- Sensibilidade para a necessidade informacional de usuários reais e potenciais;

- Flexibilidade e capacidade de adaptação;

- Curiosidade intelectual e postura investigativa para continuar aprendendo;

- Criatividade;

- Senso crítico;

- Rigor e precisão;

- Capacidade de trabalhar em equipes profissionais;

- Respeito à ética e aos aspectos legais da profissão;

- Espírito associativo.

\section{TÓPICOS DE ESTUDO}

\section{Conteúdos básicos}

Os conteúdos básicos da área dividem-se em matérias comuns aos três cursos e em matérias de domínio específico:

\section{Matérias comuns}

1.1 A construção do conhecimento

Epistemologia. Metodologia da pesquisa. Heurística.

1.20 estatuto do documento

Produção de evidência versus atribuição de sentido. A informação orgânica e a inorgânica. As unidades físicas de referência: documento, peça, série, coleção, arquivo e acervo (cartorial e operacional). As unidades intelectuais de referência: assunto e função. $O$ documento como indício, prova e testemunho.

11.30 fluxo documental: da gênese ao acesso Produtores e usuários da informação (mediações e interfaces). A contextualização como ferramenta. Seleção / avaliação. Representação e comutação: polissemia e monossemia.

1.4 As instituições

Funções pragmáticas, cognitivas, estéticas e vivenciais. Gestão, custódia, conservação, depósito legal e curadoria. Patrimônio, memória, herança, cultura. 


\section{Matérias especificas}

\begin{tabular}{|l}
\hline ARQUIVOLOGIA \\
\hline Fundamentos teóricos da \\
Arquivologia: \\
História dos arquivos e da \\
Arquivologia. As interfaces da \\
Arquivologia com o Direito, a \\
Administração e a História. Os \\
princípios de proveniência, \\
organicidade, unicidade e \\
integridade. Ciclo vital dos \\
documentos: teoria das três \\
idades. Funções arquivísticas: \\
produção, avaliação, \\
classificação, descrição, \\
conservação e difusão. Bases \\
legais e éticas da profissão.
\end{tabular}

\section{A gênese documental:}

O contexto de produção dos documentos de arquivo. Modalidades redacionais antigas e contemporâneas: Paleografia e Diplomática. Caracteres extrínsecos dos documentos: categoria, gênero, espécie, tipo, sinais de validação, forma, formato $e$ suporte. Recebimento, registro, distribuição e tramitação.

\section{Avaliação:}

Valores primários e secundários. Elaboração de tabelas de temporalidade $e$ destinação de documentos: guarda temporária, guarda permanente e eliminação. Diagnóstico de arquivos.

\section{técnico:}

\section{Processamento}

Caracteres intrínsecos dos documentos: proveniência, função e teor. Análise documentária. Classificação e ordenação: fundos, grupos e séries. Descrição e elaboração

\section{BIBLIOTECONOMIA \\ Fundamentos teóricos da \\ Biblioteconomia:}

História das bibliotecas e da Biblioteconomia. O papel e a missão do bibliotecário na sociedade. As etapas de geração, tratamento, difusão, recepção e uso da informação. As interfaces da

Biblioteconomia com as demais ciências. Bases legais e éticas da profissão.

\section{Organização e tratamento da informação:}

Descrição física e temática da informação e do conhecimento. Aplicação de códigos, normas e formatos disponiveis. Uso da informática nos serviços de informação. Desenvolvimento e gestão de bancos de dados, bases de dados e bibliotecas digitais. Metodologia de análise e avaliação de sistemas de informação. Automação de unidades de informação.

\section{Recursos e serviços de informação:}

Fundamentos, princípios, processos e instrumentos do serviço de referência: seleção, aquisição, avaliação, descarte, preservação, conservação e restauração de recursos de informação. Normas para desenvolvimento de coleções Fontes de informação impressas, eletrônicas e digitais: conceitos, tipologia, acesso, utilização e avaliação. Estudo e educação de usuários. A indústria da informação: geração, produção e comercialização de documentos, fontes e serviços de informação. Serviços de referência e informação. Serviços de extensão e ação cultural.
MUSEOLOGIA

Fundamentos teóricos da Museologia:

História dos museus e da Museologia. Teoria museológica. A Semiologia aplicada ao museu. Colecionismo e novas formas de musealização. Funções científicas, educativas e sociais. As interfaces da Museologia com as demais ciências. Bases legais e éticas da profissão.

\section{Documentação:}

Aquisição, registro, classificação, indexação e inventário de acervo. Pesquisa de identificação e

contextualização. Sistemas de recuperação de informações.

Tecnologias da informação

aplicadas aos museus.

\section{Conservaçāo:}

Guarda, acondicionamento e transporte. Estudo de materiais. Condições ambientais. Conservação preventiva. Operações de intervenção.

\section{Comunicação:}

A linguagem dos objetos e sua decodificação. Comunicação visual e exposições. Recursos cenográficos. Da fruição contemplativa à argumentativa: observação, apreciação, participação, interação. Ação educativa e ação cultural. Monitoria.

Projetos editoriais: as publicações no museu. Redes e sistemas museológicos.

Gestão de programas e serviços em museus: Planejamento, organização, execução, controle, avaliação. Gestão de recursos humanos, financeiros, físicos, de produção e materiais. 
de instrumentos de pesquisa: guias, inventários, catálogos, índices e edição de textos.

Conservação:

acondicionamento, armazenamento, preservação e restauração. Tecnologias da informação aplicadas aos arquivos.

Politicas de arquivo: Jurisdição e acesso.

Programas de difusão.

Estratégias institucionais de gestão e custódia de arquivos. Compatibilização da informação: sistemas e redes. A utilização do documento de arquivo pelo produtor, pelo pesquisador e pelo cidadão.
Gestão de unidades e serviços de informação:

Princípios e evolução da administração e da teoria organizacional. Funções da administração: planejamento, organização, execução, controle, mensuração e avaliação. Gestão de marketing, de recursos humanos, de recursos financeiros, de recursos físicos, de produção e de materiais. Qualidade aplicada ao contexto das unidades serviços de informação. (grito meu)

\section{Conteúdos diversificados}

No caso de as IES adotarem fórmulas pluridisciplinares - seja para promover ênfases especificas em determinados aspectos das carreiras, seja para transformá-las em complementação dos conhecimentos auferidos em outras -, é preciso prever as articulações possiveis com os cursos afins, dentro e fora da instituição.

Quanto aos cursos seqüenciais, podem apresentar diferentes niveis de abrangência. $O$ acesso a eles é estabelecido pelas próprias IES e não implica a realização do mesmo processo seletivo empregado para as carreiras convencionais. Devem ser mais curtos e ágeis, conferindo certificado de nivel superior aos que os concluem e habilitando-os a ingressar no mercado de trabalho para o exercício de determinadas profissões ainda não formalmente reconhecidas.

\section{DURAÇÃO DOS CURSOS}

Os cursos de Arquivologia, Biblioteconomia e Museologia deverão ter uma carga horária mínima de 2400 horas, incluidas as dedicadas a estágios e atividades complementares.

\section{ESTÁGIOS E ATIVIDADES COMPLEMENTARES}

Mecanismos de interação do aluno com o mundo do trabalho em sua área, os estágios são desenvolvidos no interior dos programas do curso, com intensidade variável segundo a natureza das matérias, sob a responsabilidade imediata de cada docente. Constituem instrumentos privilegiados para associar desempenho e conteúdo de forma sistemática e permanente. A carga horária destinada a estágios deve corresponder, no mínimo, a 10\% da carga total de cada curso.

Recomenda-se ainda o desenvolvimento de atividades complementares de monitoria, pesquisa, participação em seminários e congressos, visitas programadas, trabalhos de conclusão de curso e outras atividades acadêmicas e culturais, igualmente orientadas por docentes (de preferência em regime de tutoria), com vistas à paulatina autonomia intelectual do aluno.

As IES devem garantir espaço para o processo de auto-formação, em que o aluno, devidamente orientado, elabora seu perfil especifico, aprofundando-se em conteúdos para os quais se sente vocacionado e adquirindo as habilidades instrumentais que the faltam para um bom desempenho profissional. 


\section{ESTRUTURA GERAL DOS CURSOS}

\section{Estrutura modular}

Os conteúdos curriculares deverão ser desenvolvidos com o máximo de flexibilidade, de modo a permitir aos alunos a aquisição de competências e habilidades e a corresponder a seus interesses específicos. Os Projetos Pedagógicos das IES definirão, nesse sentido, as modalidades de seriação, o sistema de créditos e pré-requisitos, as matérias opcionais, as combinações que permitem habilitações específicas e os cursos seqüenciais, dimensionando, entre outros aspectos, a articulação da teoria e da prática, o sistema de avaliação do processo ensino-aprendizagem e as interfaces dos cursos com a pós-graduação e com o mercado de trabalho.

\section{Tamanho da turma}

As turmas deverão ter, no máximo, 40 alunos.

\section{Corpo Docente}

Em virtude de seu caráter profissional, os cursos exigem, na composição do corpo docente, uma preponderância de pessoal com titulação especifica na área, tanto quanto possivel em nível de pós-graduação (Mestrado e Doutorado), respeitando as proporções indicadas na legislação em vigor.

\section{Conexão com a avaliação institucional}

Todo processo de avaliação implica, a partir de objetivos pré-estabelecidos, a mensuração dos resultados obtidos, em função dos meios disponibilizados. Deste modo, variáveis como qualificação, titulação, regime de trabalho, infra-estrutura de pesquisa etc., que são de responsabilidade das IES e de seus mantenedores, devem ser referenciais para todo e qualquer processo de avaliação.

As IES adotarão formas alternativas de avaliação que favoreçam a verificação de: a) desempenho técnico-cientifico (clareza, fundamentação, perspectivas divergentes, pertinência, inter-relações e domínio de conteúdos, questionamentos, síntese, soluções alternativas); b) desempenho didático-pedagógico (cumprimento de objetivos, integração de conteúdos, procedimentos metodológicos e material de apoio); c) desempenho de aspectos atitudinais (participação, assiduidade, ética, criatividade etc.).

As avaliações serão realizadas de acordo com a periodicidade do curso, competindo às IES a escolha de métodos e técnicas que priorizem aspectos qualitativos. Cabe-lhes ainda acompanhar o rendimento dos discentes ao longo do curso, com o intuito de descobrir as razões do baixo desempenho e/ou da evasão escolar.

\section{Avaliações Periódicas}

As avaliações têm como foco a melhoria contínua das atividades docentes e discentes, contemplando, a par do desempenho acadêmico, a produção científica, os serviços de extensão à comunidade e a melhoria contínua dos processos de apoio administrativo às atividades acadêmicas. Tais avaliações deverão tomar por base dados e indicadores específicos, mediante instrumentos que meçam a formação dos estudantes tanto em termos de conhecimentos teóricos, como práticos.

\section{Padrões de Qualidade}

Visando ao padrão de qualidade dos Cursos, estes deverão estar atentos para: 
a) a articulação de seus projetos pedagógicos com o projeto global das IES em que estão inseridos;

b) a qualificação permanente do corpo docente;

c) a manutenção da excelência acadêmica e a criação de estrutura de acompanhamento do egresso, no sentido de verificar sua inserção profissional;

d) a constante melhoria das condições estruturais dos Cursos no que se refere a bibliotecas, laboratórios de ensino e pesquisa e serviços de treinamento e aperfeiçoamento profissional;

e) o incentivo à produção docente e discente;

f) a instituição de intercâmbio entre os diferentes programas de formação no Brasil e no exterior, mediante o estabelecimento de parcerias com outras entidades;

g) a promoção de programas de divulgação profissional e de educação continuada em diferentes niveis (extensão, aperfeiçoamento e pós-graduação lato e stricto sensu).

\section{Interface dos cursos com a pós-graduação}

É condição fundamental para o desenvolvimento desta proposta a articulação entre ensino, pesquisa e extensão, que deverá ser garantida pelas instituições não só pela infra-estrutura material e de pessoal, mas sobretudo pela constituição de ambientes que envolvam alunos de graduação, pós-graduandos e profissionais da área num processo de reflexão crítica e troca de experiências, permitindo a interlocução entre a universidade e a sociedade.

As IES devem, nesse sentido:

a) estimular a disseminação e divulgação da produção científica da graduação e da pósgraduação nos diferentes meios de comunicação;

b) promover seminários, debates, fóruns, oficinas, grupos de pesquisas e outras atividades que integrem os dois niveis;

c) assegurar a participação de mestrandos nas atividades da graduação e de graduandos nas atividades da pós-graduação, visando intercâmbio de experiências e informações;

d) incentivar a discussão dos conteúdos de ambos os cursos, de modo a identificar pontos comuns e a aprofundar conhecimentos. 
ANEXO 2: Pós-Graduação - Strictu-Senso - Ciência da Informação 
- UFPB

\section{CURSO DE PÓS-GRADUAÇÃO EM CIÊNCIA DA INFORMAÇÃO - UFPB - MESTRADO}

Coordenador: Carlos Xavier de Azevedo Netto

Vice-coordenadora : Joana Coeli Ribeiro Garcia

\section{Área de Concentração: Informação, Conhecimento e Sociedade}

A área de concentração: Informação, Conhecimento e Sociedade objetiva estimular estudos e pesquisas que visem a reflexão crítica a partir das temáticas de duas linhas, a- Memória, organização, acesso e uso da informação e b- Ética, gestão e políticas de informação como subsídios a consolidação científica da área de ciência da informação em nível nacional e internacional. Estes estudos tomam como base as descrições dos grupos de trabalho da Associação Nacional de Pesquisa e Pós-graduação em Ciência da Informação (ANCIB).

\section{1 - Linha de Pesquisa: Memória, Organização, Produção e Uso da Informação}

A linha de pesquisa: memória, organização, produção e uso da informação incorpora: preservação da memória, representação de informação e de conhecimento, web semântica, usos e impactos da informação

\section{Nome do Docente / E-mail}

Carlos Xavier de Azevedo Netto - UFPB (carlosxavier @occsaufob, br)

Dulce Amélia de Brito Neves - UFPB (dulcemelogmail.com)

Francisca Arruda Ramalho - UFPB (artranciscabhotmall com)

Guilherme de Ataide Dias - UFPB (gulhermeatade(onab.com)

Marcos Galindo - UFPE (galindodurpabr)

Mirian de Albuquerque Aquino - UFPB (ririabugomanilcom)

Olga Maria Tavares - UFPB (olgatavaresohotmailcom)

Ricardo Prudêncio - UFPE (pudencionicardo@omalicom)

\section{2-Linha de Pesquisa: Ética, Gestão e Políticas de Informação}

A linha de pesquisa: ética, gestão e políticas de informação incluem estudos sobre: ética e informação, inclusão social, gestão do conhecimento, gestão de unidade, de serviços e produtos de informação, políticas de informação: cultural, científica e tecnológica.

\section{Nome do Docente / E-mail}

Eliany Alvarenga de Araújo - UFPB (y alvarenga@gmal com) Joana Coeli Ribeiro Garcia - UFPB (Goantcoeliouol combr) Maria Auxiliadora Diniz de Sá - UFPB (arurseáopenlie,con)
PESUUSE NOSTR

Pesquise aqui...

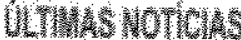

14 de Abril de 2007

07/12/2005 - VI ENANCIB Resultado do Prêmio ANCIB 2005 de Melhores Teses e Dissertações

\section{EverTos}

\section{Endereço}

Escola de Ciência da Informação - UFMG Av. Antônio Carlos, 6627 sala 4019 31270-010 Belo Horizonte, MG Fone: +55 (31) 34995208 
- UFBA

\section{UNIVERSIDADE FEDERAL DA BAHIA - UFBA}

\section{PROGRAMA DE PÓS-GRADUAÇÃo EM CIÊNCIA DA INFORMAÇÃo}

Área de Concentração: Informação e Conhecimento na Sociedade Contemporânea

Início dos Cursos: Mestrado, 1998

Endereço: UFBA/ICI: Avenida Reitor Miguel Calmon s/n - Canela Salvador - BA - Brasil - CEP: 58059-900

TEL: (0XX71) 336-6755 - FAX: (0XX71) 336-6574

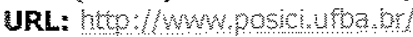

E-mail: posicioustos.

Coordenador: Nanci Oddone

\section{Linhas de Pesquisa (LP):}

INFORMAÇÃO E CONTEXTOS SOCIO-ECONÔMICOS (1)

TEORIA E GESTÃO DO CONHECIMENTO (2)

\section{Nome do Docente / E-mail}

BAIARDI, Amilcar LP: (1) / balardioufte br

BALANCO, Paulo LP: (1) / balanco Quftoa br

BURNHAM, Terezinha Fróes LP: (2) / troesbioufba br

CUSTÓDIO, Kátia Maria Coelho de C. LP: (1) / katenearvahoguel.combr

JAMBEIRO, Othon LP: (1) / othonoufbator

SANTOS, Zeny Duarte dos LP: (2) / zenvds(uffipa on

SILVA, Helena Pereira LP: (1) / helenans(a)uta.

TEIXEIRA, Francisco Lima LP: (2) / tereirauUfus br

VARELA, Aida V. LP: (2) / aidavarelagizipmall.combr

\section{Programa: UFBA - Mestrado 1998}

Área de Concentração: Estratégias de disseminação da Informação

\section{Linhas de Pesquisa / Ementas}

Teoria e Gestão do Conhecimento: Compreende estudos da relação intormação e conhecimento; informação e tecnologias de informação e comunicação; informação e processo cognitivo; da inteligência organizacional, abrangendo gestão da informação e gestão do conhecimento. Inclui a compreensão: do desenvolvimento do conhecimento na Sociedade; e da definição da Ciência da Informação e sua relação com a epistemologia.

Informação e Contextos Socio-Econômicos: Compreende estudos da história e das relações da informação com a economia, com os processos políticos, com a inclusão social e digital, com a vida social e cultural, e com a identidade nacional. Abrange a compreensão do Estado, das empresas e da sociedade civil na organização, gestão e regulação nacional e internacional da informação.

\section{Dados baseados no documento:}

Programas de Pós-Graduação em Ciência da Informação no Brasil , elaborado pelo Núcleo de Produção Científica da Escola de Comunicação e Artes (ECA) da Universidade de São Paulo (USP), sob a coordenação da Profa. Dra. Dinah Agular Población, 2003.

\section{PESWU⿺辶寸 WOSTE}

Pesquise aquí...

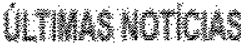

14 de Abril de 2007

07/32/2005 - VI ENANCIB Resultado do Prêmio ANCIB 2005 de Melhores Teses e Dissertações

\section{EvEnTos}

Endereço:

Escola de Ciência da Informacăo - UFMG Av. Antônio Carlos, 6627 sala 4019 31270 010 Belo Horizonte, $M G$ Fone: +55 (31) 34995208 


\section{UFMG}

\section{UNIVERSIDADE FEDERAL DE MINAS GERAIS - UFMG}

\section{PROGRAMA DE PÓS-GRADUAÇÃO EM CIÊNCIA DA INFORMAÇÃO}

Área de Concentração: Produção, Organização e Utilização da Informação

Início dos Cursos: Mestrado, 1976. Doutorado, 1997.

Endereço: Av. Antônio Carlos, 6627 - C.P.1606 - Campus da Pampulha - Belo Horizonte - MG - Brasil - CEP: $30161-970$

TEL: (0XX31) 3499-6103/5206 - FAX: (0XX31) 3499-5207

URL: bttol/wwweclufmg.bropge

E-mail: pogciaseciumg br

Coordenadora: Marlene de Oliveira

\section{Linhas de Pesquisa (LP):}

INFORMAÇÃO CULTURA E SOCIEDADE (1)

INFORMAÇÃO GERENCIAL E TECNOLÓGICA (2)

ORGANIZAÇÃO E USO DA INFORMAÇÃO (3)

\section{Nome do Docente / E-mail:}

ALVARENGA, Lídia LP: (3) / Udiaavarengaseciufmo,br ANDRADE, Maria Eugênia LP: (2) / eugeniaandradẹeciumm br AUN, Marta Pinheiro LP: (2) / martapinheirolaeci.ufme br BARBOSA, Ricardo R. LP: (2) GP; 8(L)/ ricardobarboszacied, ump br BAX, Marcello Peixoto LP: (2) / baxpeciumbing BORGES, Mônica Erichsen N. LP: (2) / mmassifôeciutumg br CABRAL, Ana Maria Rezende LP: (1) / acabraloeciufmo by CENDON, Beatriz Valadares LP: (2) / cendongeci, whoth br CRIVELLARI, Helena Maria Tarchi LP: (2) / helenacrivelangecinmo br DIAS, Eduardo José Wense LP: (3) / ediasoucciumpor DUMONT, Ligia Maria Moreira LP: (1) / dumontoeciumo b: FERREIRA, Marta Araújo Tavares LP: (2) / marauioujeci.umg.b: MARTELETO, Regina Maria LP: (1) / reginamaroecumg,ur MOURA, Maria Aparecida LP: (3) / mamouracieciumobr NAVES, Madalena Martins Lopes LP: (3) / madalena(Seciummo br NEVES, Jorge Tadeu de Ramos LP: (2) / Itmewes (⿹勹巳eci ufno br

OLIVEIRA, Marlene de LP: (2) / mürenequedutmo,br

SANTOS, Alcenir Soares dos LP: (1)/alcenimoci. whmo br

\section{Programa: UFMG - Mestrado 1976; Doutorado 1997}

Área de Concentração: Produção, organização e utilização da informação

\section{Linhas de Pesquisa / Ementas}

Gestão da Informação e do Conhecimento: Focaliza aspectos relacionados com a gestão da informação e do conhecimento em contextos organizacionais. Alguns dos tópicos estudados são: acesso, disseminação e uso da informação em organizações, fontes e serviços de informação para negócios, gestão do conhecimento tecnológico, informação e aprendizagem organizacional, informação e empreendedorismo, informação e gestão estratégica, inteligência empresarial, políticas de informação e inovação e tecnologias da informação para a gestão.

Informação, Cuitura e Sociedade: Investiga a informação enquanto fenômeno social, apreendendo-a a partir de seus domínios epistemológicos e contextos sociais. São contemplados estudos e pesquisas que abrangem as inter-relações da informação. As pesquisas têm como elementos comuns a preocupação em discutir problemas relativos à democratização do acesso à informação, onde se procura evidenciar, também, as contradições, os limites e as alternativas que se apresentam no âmbito da sociedade da informação.

Organização e Uso da Informação: Estuda aspectos do tratamento e do uso da informação, procurando explorar a interação existente entre as duas funções nos sistemas de informação e de recuperação da informação. Inclui estudos sobre descrição física e temática de documentos tradicionais e digitais, bem como estudos bibliométricos.

\section{Dados baseados no documento:}

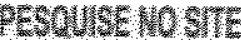

Pesquise aquil..

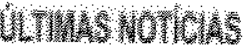 \\ 14 de Abril de 2007}

07/12/2005 - VI ENANCIB Resultado do Prêmio ANCIB 2005 de Melhores Teses e Dissertaçôes

\section{Eventos}

Endereço:

Escola de Ciência da Informação - UFMG Av. Antônio Carlos, 6627 sala 4019 31270-010 Belo Horizonte, MG Fone: +55 (31) 34995208 
Programas de Pós-Graduação em Ciência da Informação no Brasil , elaborado pelo Núcleo de Produção Científica da Escola de Comunicação e Artes (ECA) da Universidade de São Paulo (USP), sob a coordenação da Profa. Dra. Dinah Aguiar Población, 2003.

Copyright (C) 2005 - ANCIB Associação Nacional de Pesquisa e Pós-Graduação em Ciência da Informação Todos os direitos reservados. Năo é permitida a reproduçẫo sem prévia autorização.

Pesquise aqui.. 
- UFRGS

\section{UNIVERSIDADE FEDERAL DO RIO GRANDE DO SUL}

\section{PROGRAMA DE PÓS-GRADUAÇÃo EM COMUNICACÃ̃o E INFORMAÇÃo}

Endereço: Rua Ramiro Barcelos, 2705 - $2^{\circ}$ andar - Bairro Santana - CEP: 90.035 - 007 - Porto Alegre - RS

Fone: (51) 3316 5116

Fax: (51) $3316-5368$

Email: pogcomoufras br

URL: hto:/Wmoworomufres,br

Coordenadora: Ida Regina Chitto Stumpf

Area de Concentração: Comunicação e Informação

Nivei: Mestrado (1995) e Doutorado (2000)

Linha de Pesquisa 1: Informação, Tecnologias e Práticas Sociais

Esta linha contempla pesquisas de cunho teórico, metodológico e aplicado, enfocando a geração, o desenvolvimento e o uso da informação e das tecnologias da informação e da comunicação, para compreensão da cibercultura, da interação mediada por computador e dos demais fenômenos ligados à dinâmica das práticas sociais.

\section{Professores: Alex Primo, Ida Regina C.Stumpf, Sonia Caregnato, Sérgio Capparelli e Virgínia} Fonseca

Linha de Pesquisa 2: Comunicação, Representações e Práticas Culturais

Esta linha contempla pesquisas de cunho teórico, metodológico e aplicado, vinculadas às representações midiáticas e às práticas culturais e sua relação com os meios, compreendendo: os processos de comunicação e de produção de sentido, imagens e discursos: representações e poderes constituidos no campo da comunicação e da política; identidades, diversidades culturais e memória social; consumo cultural e os processos de recepção; sociabilidade cultura popular e cidadania.

\section{Professores: Iiza Torinho, Karla Muller, Nilda Jacks, Marcia Benetti Machado, Maria Helena Weber} Valdir Morigi

Copyright (c) 2005 - ANCIB Associação Nacional de Pesquisa e Pós-Graduação em Ciência da Informação Todos os direitos reservados. Não é permitida a reprodução sem prévia autorização.

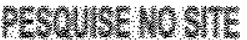

Pesqiuise aqui...

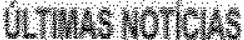

14 de Abril de 2007

07/12/2005 - VI ENANCIB . Resultado do Prêmio ANCIB 2005 de Melhores Teses e Dissertaçöes

\section{EVEMTOS}

\section{Endereç:}

Escola de Ciência da Informação - UFMG Av. Antönio Carlos, 6627 sala 4019 31270-010 Belo Horizonte, $\mathrm{MG}$ Fone: +55 (31) 34995208

Pesquise aqui.. 
- UFSC

\section{UNIVERSIDADE FEDERAL DE SANTA CATARINA - UFSC}

\section{PROGRAMA DE PÓS-GRADUAÇÄO EM CIÊNCIA DA INFORMAÇÄO}

Área de Concentração: Gestão da Informação

Início dos Cursos: Mestrado, 2003.

Endereço: UFSC/CIN: Campus Universitário - Trindade Florianópolis - SC - Brasi

CEP: $88040-900$

TEL: (0XX48) 331-8516 - FAX: (0XX48) 331-8516

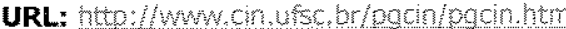

E-mail: pgcingein utscbr

Coordenador: Miriam Vieira da Cunha

Linhas de Pesquisa (LP):

FUUXO DA INFORMAÇÃO (1)

PROFISSIONAIS DA INFORMAÇÃO (2)

\section{Nome do Docente / E-mail}

ABREU, Aline LP: (1) almedudeps unsc br

BASTOS, Rogério C. LP: (1) rogentoO Selufsc br

BLATTMANN, Úrsula LP: (1) ursulagcedufsc br

CAFE, Ligia LP:(1) Iiglacicinufse ob

COSTA, Maria Damiani LP: (1) maridacostágig combr

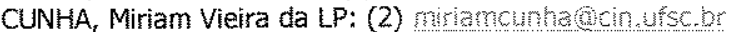

PEREIRA, Magda Chagas LP: (2) megdạcinufsc.br

RADOS, Gregório Jean Varvakis LP: (1) oregoọdeps.ufscobr

SILVA, Edna Lúcia da L.P: (1) ednaluguol com br

SOUZA, Francisco das Chagas de LP: (2) souzadama arma. hi

VIEIRA, Angel Freddy Godoy LP: (1) godoyocin utsebr

\section{Programa: UFSC - Mestrado 2003}

Área de Concentração: Gestão da Informaçẫo

\section{Linhas de Pesquisa / Ementas}

Fluxo da Informação: Estudar os canais de produção, distribuição e circulação da informação, os processos e suportes informacionais e a apropriação da informação nas unidades de informação, visando construir suportes teóricos para a compreensão do funcionamento das unidades de informação e para o entendimento da dinâmica dos fluxos de informação na sociedade contemporânea.

Profissionais da Informaçäo: Estudar as necessidades de busca e uso de informação da sociedade, em diferentes setores, que determinam a configuração das atividades dos gestores da informação, visando construir metodologias que permitam avaliar as condições de oferta de educação e capacitação profissional nas áreas que compóem o campo de atuação dos profissionais de ciência da informação.

\section{Dados baseados no documento:}

Programas de Pós-Graduação em Ciência da Informaçăo no Brasil , elaborado pelo Núcleo de Produção Científica da Escola de Comunicação e Artes (ECA) da Universidade de São Paulo (USP), sob a coordenação da Prota. Dra. Dinah Aguiar Población, 2003.

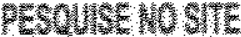

Pesquise aqui...

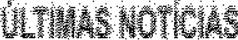 \\ 14 de Abril de 2007}

3 07/12/2005 - VI ENANCIB Resultado do Prêmio ANCIB 2005 de Melhores Teses e Dissertaçōes

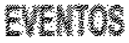

\section{Endereç:}

Escola de Ciência da Informação - UFMG Av. Antônjo Carlos, 6627 sala 4019 31270-010 Belo Horizonte, MG Fone: +55 (31) 34995208 


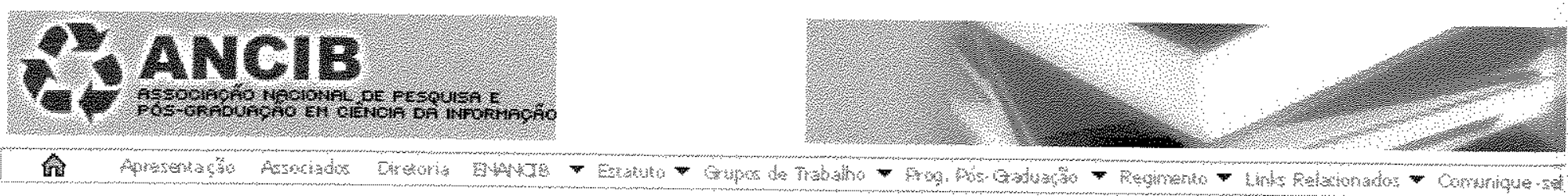

- UNB

\section{UNIVERSIDADE DE BRASÍLIA - UnB}

\section{PROGRAMA DE PÓS-GRADUAÇÃO EM CIÊNCIA DA INFORMAÇÃO E DOCUMENTAÇÃO \\ Área de Concentração: Transferência da Informação \\ Início dos Cursos: Mestrado, 1978. Doutorado, 1992.}

Endereço: UNB/FA/CID: Campus Universitário "Darcy Ribeiro" - Asa Norte Caixa Postal 04561 - Brasília - DF Brasil

CEP: $70919-970$

TEL: (0XX61) 3307-2410 TEL/FAX: (0XX61) 3307-2842-FAX: (0XX61) 3273-8454

URL: hoto:/Wwid cid unb holpos

E-mail: vocinfounb, bn

Coordenadora: Profa. Sely Costa

\section{Linhas de Pesquisa (LP):}

GESTÃO DA INFORMAÇÃO E DO CONHECIMENTO (1)

ARQUITETURA DA INFORMAČ̃O (2)

COMUNICAÇÃO DA INFORMAÇÃO (3)

\section{Nome do Docente / E-mail}

AMARAL, Sueli Angélica do LP: (1) / samaraloumb b:

ANTUNES, Walda de Andrade LP: (1) / we-cobiowa-corbicom:tr

BAPTISTA, Sofia Galvão LP: (1) / sofiagounb. Wr

COSTA, Sely Maria de Sousa LP: $(1,3)$ / selmarount br

CUNHA, Murilo Bastos da LP: (1) / murilobchunb br

LIMA-MARQUES, Mamede LP: (2) / mamedeounb br

LOPEZ, Andre P. A. (1) / apdopezoconreweb combr

MANINI, Miriam (1) / mpmaninicuolcombr

MIRANDA, Antonio L.C. de LP: (3) / cmirandaldunt by

MUELLER, Suzana Pinheiro Machado LP: $(1,3)$ / muellergunb br

ROBREDO, Jaime LP: (2) / jrobredodunb br

RODRIGUES, Georgete Medleg LP: (1) / georcetetionb b:

SIMEAO, Elmira L.M. (3) / elmiraOunb.or

SOUSA, Renato Tarciso (1) / rsousacumb or

SUAIDEN, Emir José LP: (1) / emirounbur

TARAPANOFF, Kira LP: (1) / kat309Gunb.br

ZANDONADE, Tarcisio (3) / tar.zan @unb.br

\section{Programa: UnB - Mestrado 1978; Doutorado 1992}

Área de Concentração: Transferência da informação

\section{Linhas de Pesquisa / Ementas}

Arquitetura da Informação: Estudos teóricos e práticos sobre a análise da informação, indexação, estruturas informacionais, representação do conhecimento e recuperação da informação.

Comunicação da Informação: Modelos e processos da comunicação da informação científica, tecnológica, comunitária, arquivistica, organizacional e para negócios. Suportes informacionais tradicionais e eletrônicos. Direito autoral. Influência dos contextos acadêmico, industrial, empresarial, organizacional e social no comportamento informacional.

Gestão da Informação e do Conhecimento: Estudos teóricos, metodológicos e práticos sobre gestão da informação e do conhecimento em sistemas de informação, bibliotecas, arquivos e demais unidades de informação e sobre a formação e mercado de trabalho dos profissionais da informação. Análise das necessidades e dos comportamentos dos individuos e das comunidades na busca e no uso da informação.

\section{PESOUNSE WOSTE}

Pesquise aquì..

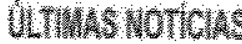

14 de Abril de 2007

S. 07/12/2005 - VI ENANCIB Resultado do Prêmio ANCIB 2005 de Melhores Teses e Dissertações

\section{EVEVIOS}

\section{Endereço:}

Escola de Ciência da Informação - UFMG Av. Antônio Carlos, 6627 sala 4019 31270-010 Belo Horizonte, MG Fone: +55 (31) 34995208 
- UNESP

\section{UNTVERSIDADE ESTADUAL PAULISTA - UNESP}

\section{PROGRAMA DE PÓS-GRADUAÇÃO EM CIÊNCIA DA INFORMAÇÃO}

Área de Concentração: Informação, Tecnologia e Conhecimento

Cursos: Mestrado acadêmico e Doutorado

Início dos Cursos: Mestrado, 1998.

Endereço: Campus Marilia: Av. Hygino Muzzi Filho, 737 - Campus Universitário Marília - SP - Brasil - CEP: 17525900

TEL: (OXX14) 3402-1300

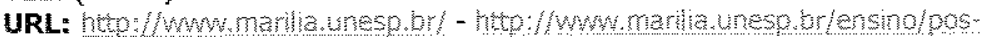

Grad/ciancia informacaolapresentaca हn m

E-mail: posoradbmatlia unest.br

Coordenadora: Silvana Aparecida B. Gregório Vidotti

Vice-Coordenadora: Mariângela Spotti lopes Fujita

\section{Linhas de Pesquisa (LP):}

INFORMAÇÃO E TECNOLOGIA (1)

ORGANIZAÇÃO DA INFORMAÇÃO (2)

\section{Nome do Docente / E-mail}

BARROS, Maria Helena T.C. de LP: (1) / mobamosomarilia.uneso.br

FADEL, Bárbara LP: (1) / bafadeicterra combr

FOREST, Miriam Cell P. Porto LP: (1) / mfforestiout com, br

FUJTT, Mariângela Spotti Lopes LP: (2) / goldstaroftastutudor

GUIMARÃES, José Augusto Chaves LP: (2) / Oulmajaçumarilia uneso br

MORAES, João Batista Ernesto de LP: (2) / jotâmarila unesp.br

MUCHERONI, Marcos Luiz LP: (1) / mucheronisundanet br

MURGUIA MARAÑON, Eduardo Ismael LP: (1) / murcuia omarila unesp br

NARDI, Maria Isabel Asperti LP: (2) / belnardiumi zaz,com, br

SANTOS, Plácida L. V. A Costa LP: (1) / pacidadomarila unesp br

SMIT, Johanna Wihelmina LP: (2) / chdjoke@usp. bs

VIDOTTh, Silvana Aparecida B. Gregório LP: (1) / vidotivamarilia, unesp br

\section{Programa: UNESP - Mestrado 1998}

Área de Concentração: Informação, tecnologia e conhecimento

\section{Linhas de Pesquisa / Ementas}

Informação e Tecnologia: Estudos e pesquisas relacionados à geração, transferência, utilização e preservação da informação e dos documentos nos ambientes científico, tecnológico, empresarial e da documentação em geral, associados a métodos e instrumentos proporcionados pelas tecnologias da informação e da comunicação.

Organização da Informação: Organização da informação como elemento de qualidade na recuperação: pressupc̃e referenciais teóricos e metodológicos de organização do conhecimento em análise, síntese e representação e a elaboração de produtos documentátios com aplicabilidade na formação e atuação profissional.

\section{Dados baseados no documento:}

Programas de Pós-Graduação em Ciência da Informação no Brasil , elaborado pelo Núcleo de Produção Científica da Escola de Comunicação e Artes (ECA) da Universidade de São Paulo (USP), sob a coordenação da Profa. Dra. Dinah Aguiar Población, 2003.
PESWUEE NONTE

Pesquise aqui...

\section{Utivins Noticias \\ 14 de Abril de 2007}

207/12/2005 - VI ENANCIB Resultado do Prềnio ANCIB 2005 de Melhores Teses e Dissertações

\section{Erenos}

\section{Endereco:}

Escola de Ciência da Informação - UFMG Av. Antônio Carlos, 6627 sala 4019 31270-010 Belo Horizonte, MG Fone: +55 (31) 34995208 


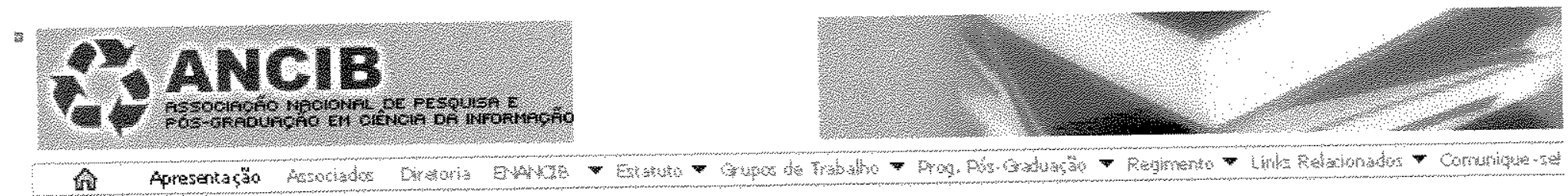

\section{- USP}

\section{UNIVERSIDADE DE SÃO PAULO - USP/Escola de Comunicações e Artes}

\section{PROGRAMA DE PÓS-GRADUAÇÃo EM CIÊNCIA DA INFORMAÇÃo}

Área de Concentração: Cultura e Informação

Início dos Cursos: Mestrado e Doutorado: 2006 (Origem: Mestrado, 1972. Doutorado, 1980, Programa de PósGraduação em Ciências da Comunicação)

Endereço: ECA/USP: Av. Prof. Lúcio Martins Rodrigues, 443, $2^{\circ}$ andar São Paulo - SP - Brasil - CEP: 05508-900

TEL: (OXX11) 3091-4076 - FAX: (0XX11) 3091-4325

URL: hetp:/Www eca usp.br/

E-mail: codousp br

Coordenadora: Profa. Dra. Marilda Lopes Ginez de Lara

\section{Linhas de Pesquisa (LP):}

ACESSO À INFORMACCÃO (1)

MEDIAÇ̃̃O E AÇÃO CULTURAL (2)

\section{Nome do Docente / E-mail}

ALMEIDA, Maria Christina Barbosa de LP: (2) / mobdalmecuspp br

COELHO NETTO, José Teixeira LP: (2) / jotekeloususpr

CINTRA, Anna Maria Marques LP: (1) / acintra(i) sticom, br

FERREIRA, Sueli Mara Soares Pinto LP: (1) / smerretiuso br

FUJINO, Asa LP: (1) / asa. funnoggmail.com

GROSMANN, Martins LP: (2) / amomannousp br

LARA, Marilda Lopes Ginez de LP: (1) / laramaßousp.br

KOBASHI, Nair Yumiko LP: (1) / nvkobastiouse br

NORONHA, Daisy Pires LP: (1) / dasynor(ussp br

PASSARELLI, Brasilina LP: (1)/ inagofuturouspbr

PERROTTI, Edmir LP: (2) / perrotícusp br

POBLACIÓN, Dinah A. de M. Aguiar LP: (1) / dinahmapóaso br

SMIT, Johanna Wihelmina LP: (1) / codjokeousse. br

TÁLAMO, Maria de Fatima G.M. LP: (1) / montalabusebr

VERGUEIRO, Waldomiro C.S. LP: (1) / wdesverguUusp br

\section{Programa: USP - Mestrado 1972; Doutorado 1980 (Programa C.Comunicação - Área de Concentração C. da Informação e Documentação); Programa de Pós-Graduação em Ciência da Informaçäo; 2006}

Área de Concentração: Cultura e Informação

\section{Linhas de Pesquisa / Ementa}

Acesso à Informação: Estudos teóricos e metodológicos nos aspectos relacionados à produção, organização para transferência e uso visando o acesso e a apropriação da informação. A abordagem desses conteúdos tem como princípio a observação dos modos de produção da sociedade contemporânea, os contextos sócio-culturais e econômicos de difusão e divulgação da informação, a diversidade de públicos e, em última análise, a função social da informação.

A linha de pesquisa organiza seus conteúdos visando contemplar diferentes facetas do acesso à informaçẫo:

a) estudos bibliométricos, cientométricos e informétricos da produção científica e técnica

b) construcão da informação documentária através da análise das condições, processos e instrumentos de organização da informação para transferência e apropriação, observando seu desenvolvimento no universo da linguagem;

c) difusão da informação tendo como foco a emissão, a recepção e as diferentes configurações dos públicos;

d) estudos sobre apropriação da informação em diferentes contextos culturais e por audiências diversas.

e) pesquisa, concepção, planejamento, implementação e avaliação de sistemas e produtos informacionais;

e) pesquisa, concepção, planejamento e projetos de arquitetura de sistemas virtuais no contexto da interação com diferentes públicos alvo.

A abordagem utiliza um referencial interdisciplinar dialogando com diferentes áreas do saber, como a Lingüística, a Lógica, as Ciências Sociais, a Administração, a Educação, a Psicologia, a Ciência da Computação, a Arquitetura, a Antropologia e Sociologia entre outros.

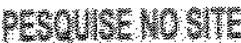

Pesquise aqui...

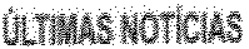

14 de Abril de 2007

07/12/2005 - VI ENANCIB Resultado do Prêmio ANCIB 2005 de Mehores Teses e Dissertaçôes

\section{EvETOS}

\section{Endereco:}

Escola de Ciência da Informaç̧̃̃o - UFMG Av. Antônio Carlos, 6627 sala 4019 31270 -010 Belo Horizonte, MG Fone: +55 (31) 34995208 
Mediação e Ação Cultura: Baseada nos estudos de Poltítica Cuttural - entendida como ciência da organizaçăo dos sistemas culturais - esta linha apresenta-se como un campo de natureza processual, situacional e relacional que se propõe a construir teoricamente um conhecimento do mundo da cultura tal como ele se revela nos constructos informacionais formalizados (biblioteca, museu, sistemas virtuais etc) como nele intervir com instrumentos determinados visando o apoio à produção, distribuição, acesso e uso dos bens culturais, promovendo a socialização do conhecimento e da informação correspondente. A ação cultural é entendida como processo de criação ou organização das condições necessárias para que as pessoas e grupos inventem seus próprios fins no universo da cultura institucionalizada, e a mediação cultural como o domínio das ações que visam fazer a ponte entre a obra de cultura, seu produtor e seu público a partir das instituições formais de modo a permitir que os sentidos de uma e outro, além dos objetivos do terceiro, possam convergir para um ponto comum. A linha de pesquisa organiza seus conteúdos visando contemplar criticamente:

a) O sistema de produção de sentido cultural, em particular a produção, a circulação, a distribuição, a preservação e o uso da informação de cunho cuitural, em sua natureza própria e tendo em vista sua acessỉ̉ilidade e socialização;

b) As principais instituições desse sistema, tradicionais e contemporâneas, como a biblioteca e o museu, com seus componentes, bem como as novas midias a elas relacionadas (o universo da telemática);

c) Os programas de política cultural elaborados e executados pelos diferentes atores políticos e sociais, materializados nas figuras do Estado, das entidades da sociedade civil e da iniciativa privada.

A conjunção entre ação e mediação permite assim a configuração de estudos e proposições relativos à área e que, além de empregarem o conhecimento disciplinar de áreas de referência como a museologia, a biblioteconomia, a documentação e a arquivologia, se atualizam na interação com segmentos criativos da Sociedade da Informação possibilitando uma atuação consciente e ativa nas novas formas de mediação da informação da sociedade contemporânea. A linha conforma seus campos de estudo e reflexão de modo interdisciplinar, dialogando com outras áreas de saber como a História das Idéias, a Filosofia, a História e a Teoria da Cultura, a Sociologia, a Antropologia, o Cinema, as Artes Visuais, entre outras. 
ANEXO 3: Pós-Graduação - Latu-Senso 


\section{INBRAPEC/CENTRO DE PÓS-GRADUAÇÃO -}

\section{GESTÃO E TÉCNICAS DA QUALIDADE - SÃO PAULO}

Objetivo:

Em comprometimento com a Política da Qualidade, o objetivo geral do curso é de alcançar, através da formação dos alunos, a excelência na construção e produção do conhecimento acerca da qualidade e sua gestão, trazendo envolvimento e comprometimento, disponibilizando conhecimentos teóricos e vivenciais de empresa, permitindo que o aluno identifique problemas e soluções, aplique ações e melhoria dentro de processos da qualidade, como também maior integração com as diretrizes estabelecidas para a acreditação da empresa.

Público-alvo:

O Curso "Lato Sensu" Especialização em Gestão e Técnicas da Qualidade destinase a profissionais com formação superior, que pretendam atuar ou que atuam em empresas públicas e privadas.

\section{Disciplinas:}

1. Política e filosofia da qualidade

2. Identificação, análise e técnicas de falhas em Sistema da Qualidade

3. Direito aplicado ao sistema da qualidade

4. Metodologia científica e monografia

5. Cálculos de incerteza

6. Recursos humanos e gestão da qualidade

7. Técnicas de treinamento em qualidade

8. Gestão e registro de documentos da qualidade

9. Administração e liderança empresarial

10. Auditoria em qualidade

11. Orientação monográfica

12. Sistema da qualidade: ISO 9.000

13. Sistema da qualidade: ISO 14.000

14. Sistema da qualidade: ISO 17.025

15. Sistema da qualidade: Gestão da Responsabilidade Social SA 8000 e ISO 16.001

Coordenação:

Profa MSc. Silvia C.D. de Oliveira

\section{Carga Horária:}

376 horas (trezentos e setenta e seis horas) 


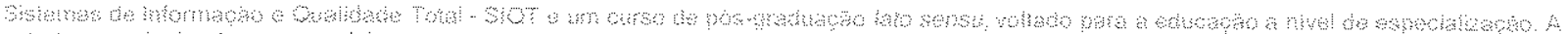

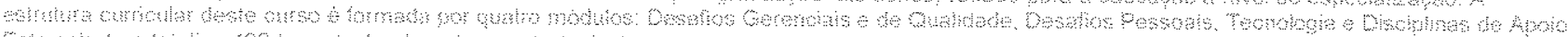

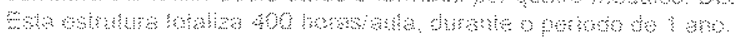

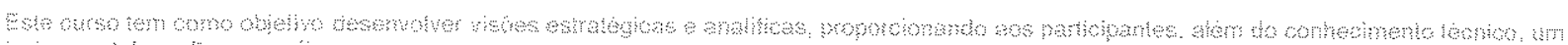
minmentat mo mes permin



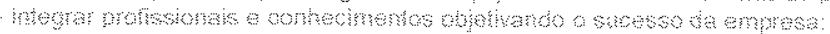

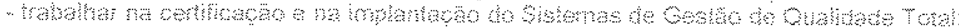

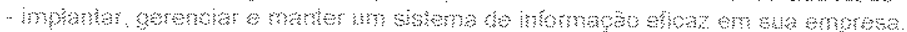

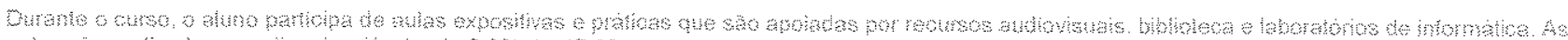

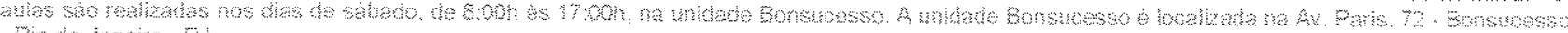

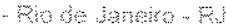

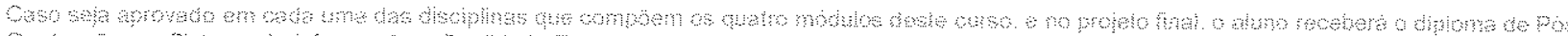

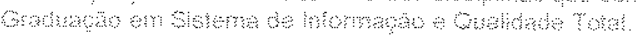

UNISUAM - Praça da Naçoses, 34 - Bonsucesso - Fio de Janeiro - RU - Tel: (0xx21) 3882-9752 Coordenacão: Prof M.Sc. Ana Cameiro - anecameirodunisuam edubr 
Objetivos do curso: Capacitar e atualizar profissionais para o exercicio de atividades administrativas em Unidades de Informação; proporcionar uma visão gerencial associada aos recursos, serviços e produtos de Unidades de Informação e fornecer referenciais teórico-metodológicos nas áreas relativas à organização da informação e aos aspectos tecnológicos da informação.

Público Alvo: Curso Superior Completo nas áreas de Biblioteconomia, Ciência da Informação, Sistemas de Informação e áreas afins. Demais interessados. O curso é elaborado para graduados, desde os que estão concluindo agora os cursos de graduação até os que já estão graduados há mais tempo. Há uma preocupação em atender o público de forma diferenciada, tanto com relação às áreas do conhecimento, como no tempo de
graduação.

Apresentação do curso: As mudanças tecnológicas e sociais ocorridas nas últimas décadas têm provocado uma grande ansiedade em profissionais que trabalham com informação, e principalmente aqueles que estão à frente de Bibliotecas, Centros de Documentação e qualquer outra unidade de informação.

A área da informação vem absorvendo os avanços da informática e das telecomunicações e os profissionais aprendendo cada vez mais a lidar com novos campos e diferentes áreas. A introdução da Informática, as facilidades das telecomunicações e a aceleração do uso de meios eletrônicos no acesso e tratamento da informação mudaram o conceito das Bibliotecas, Centros de Documentação ou qualquer outra unidade de informação, criaram necessidades de novas formas de mediação para obtenção e transferência de informação e documentos, e passaram a exigir um profissional com um perfil mais completo e com maior conhecimento e formação para continuar atuando na área da informação.

O gerenciamento de unidades de informaçäo requer, hoje em dia, conhecimentos e habilidades diferenciadas para atuar com novas práticas e diferentes profissionais, e para isso apresentamos a proposta de um curso que visa atender essa necessidade.

Justificativa da Importância: Embora exista um reconhecido curso de Biblioteconomia na cidade há mais de trinta anos nunca foi oferecido um curso de pós-graduação que atendesse a demanda existente.

A cidade e região têm uma grande concentração de universidades públicas e particulares, empresas, escolas de primeiro e segundo graus, conseqüentemente há um grande número de profissionais nesta área. Estes profissionais necessitam de atualização, especialmente voltada para as questões gerenciais, dessas unidades de informação e, comumente, cursos dessa natureza são oferecidos nos grandes centros, o que dificulta 0 acesso dos interessados a esses novos conhecimentos.

Importante salientar que o curso proposto conta com um excelente corpo docente, altamente capacitado, com atuação e formação em renomadas universidades e grande experiência acadêmica e profissional.

Programa do curso: Metodologia do Trabalho Científico. Planejamento Estratégico e Ferramentas da Qualidade para Gestores da Informação. Administração por Projetos. Gestão de Pessoas. Marketing para Unidades de Informação. Tópicos Especiais. Sistemas de Representação e Organização do Conhecimento. Noções de Arquivo e Gerenciamento Eletrônico de Documentos. Métodos e Técnicas de Indexação. Tesauro e Terminologia. Desenvolvimento de Sistemas de Informação. Sistema de Armazenamento e Recuperação de Informações (Hipermídia). Planejamento e Geração de Base de Dados

\section{Trabalho de Conclusão de Curso (TCC)}

O Trabalho de Conclusão de Curso (TCC) é uma monografia a ser desenvolvida ao longo do curso, sob orientação, abordando tema específico da área da especialização e objetiva permitir ao pós-graduando uma visão integradora dos módulos cursados e das demais atividades ao longo do curso possibilitando o melhor aproveitamento dos estudos, demonstrando domínio do objeto de estudo e capacidade de expressar-se lucidamente sobre ele. OTCC deve ser entregue até 60 dias após o término das aulas presenciais. Depois das correções e avaliação, mais 30 dias para a entrega da versão final em capa dura e disquete.

Alguns sábados (três ou quatro, no máximo), além dos previstos para as aulas presenciais, serão destinados para as atividades de orientação.

Curso Presencial: o curso oferecido é presencial, com aulas em sala, permitindo a necessária interação com o facilitador e os demais colegas, valorizando a socialização dos conhecimentos e os contatos pessoais, indispensáveis para a melhor formação dos participantes. 
Prazo de Matricula: As matrículas serão aceitas exclusivamente no periodo compreendido entre 16/01/2006 e 04/03/2006 na Diretoria de Pós-Graduação e Cursos de Extensão da UNICEP - Campus II - à Rua Miguel Petroni, 5111, Jardim Centenário, São Carlos-SP, nos horários: $2^{\mathrm{a}}$ feiras - das 8 h00 às $12 \mathrm{~h} 00$ e das $14 \mathrm{~h} 00$ às $19 \mathrm{~h} 00 ; 3^{\mathrm{a}}$ a $6^{\mathrm{a}}$ feiras - das $8 \mathrm{~h} 00$ às $21 \mathrm{~h} 45 \mathrm{e}$ aos sábados das 8 h00 às 18 h00. A data de 04/03/2006 é a data máxima para matrículas devido ao processo de seleção exigido por lei.

Local das Aulas: As aulas serão ministradas no Campus || do Centro Universitário Central Paulista à Rua Miguel Petroni, 5111, Jardim Centenário em São Carlos-SP. Excepcionalmente, algumas aulas poderão ser ministradas no Campus I da Instituição (Campus Vila Alpes). O "Campus Miguel Petroni" da UNICEP dispõe de salas de aula em módulos e laboratórios adequados, equipamentos e recursos áudio-visuais, biblioteca, amplos estacionamentos, cantina e portaria 24 horas bem como as demais condições necessárias para o oferecimento de cursos de qualidade, com segurança e tranqüilidade para todos. O "campus" fica próximo da Rodovia Washington Luis, o que também facilita o acesso.

Aulas: Aos sábados - alternados - das $8 \mathrm{~h} 00$ às $12 \mathrm{~h} 30$ e das $13 \mathrm{~h} 30$ às $18 \mathrm{~h} 00$. Duração do Curso: 20 meses. Inicio em 18/Março/2006. Cada sábado corresponde a 12 horas/aula, incluindo as atividades complementares e as de avaliação.

Datas das aulas: Estão previstas aulas nas datas: 18/03, 01/04, 06/05, 20/05, 03/06, 24/06, 08/07, 29/07, $19 / 08,02 / 09,23 / 09,07 / 10,28 / 10,18 / 11,02 / 12$ e 16/12/2006. O calendário para 2007 será divulgado posteriormente, com início previsto para a $2^{a}$ quinzena de Janeiro. Os intervalos entre as datas das aulas permitem o desenvolvimento das atividades extra-classe e os trabalhos de avaliação.

Corpo Docente: Altamente qualificado e com ampla experiência. Professores de Universidades Públicas e Particulares. Mestres e Doutores. Especialistas na área. Profissionais da área em atividade.

Material Didático: Material didático com conteúdo de qualidade e disponibilizado para todos os participantes. Publicações especializadas e séries de textos produzidos especialmente para os cursos de pós-graduação. Também, poderão utilizar a Biblioteca da UNICEP. Excepcionalmente, algumas disciplinas poderão indicar livrotexto para as aulas em substituição ao material apostilado.

Certificados: Os concluintes do curso receberão certificados de Especialistas, na área do curso, nos termos da Resolução $n^{\circ} 1$ de 3 de abril de 2001 do Conselho Nacional de Educação, válidos e reconhecidos em todo o território nacional.

Módulo nos Estados Unidos da América: O Centro Universitário Central Paulista (UNICEP) e a Indiana University of Pennsylvannia, Indiana - PA - USA (IUP) firmaram um convênio internacional para oferecer aos alunos do curso o "Executive Program in International Business Studies from Brazilian Executives from UNICEP" .É um programa de complementação de estudos do MBA - UNICEP a ser realizado nos Estados Unidos, nas instalações da IUP, com 36 horas de aulas/seminários e visitas, compreendendo estudo de casos das empresas a serem visitadas. O coordenador do convênio é o Prof. Dr. Sergio Perussi e as viagens ocorrem em julho de cada ano.

Seleção para o curso: A seleção para o curso ocorrerá através da análise do Curriculum Vitae do interessado e se dará após o prazo de encerramento das inscrições. Os candidatos selecionados serão comunicados por email ou telefone.

Coordenação Acadêmica: Prof ${ }^{a}$ Ms. Gláucia Maria Saia Cristianini, Graduada em Biblioteconomia. Mestre em Administração e Planejamento de Sistemas de Informação pela PUC - Campinas. Especialista em Sistemas Automatizados de Informação em Ciência e Tecnologia. Professora Universitária. Diretora da Biblioteca do Instituto de Ciências Matemáticas e de Computação - ICMC - USP, São Carlos-SP.

Coordenação Geral:

Pós-Graduação da UNICEP.

Prof. Dr. Alberto N. Senapeschi, Doutor em Ciências pela USP e Diretor de 
CURSOS - ADMINISTRAÇÃO / QUALIDADE

SISTEMAS DE QUALIDADE E PRODUTIVIDADE - FOCO EM SISTEMAS PARA GESTÃO

INTEGRADA

Organizado nos termos da Resolução CES 01/2001 do Conselho Nacional de Educação

$59^{\circ}$ TURMU

\title{
COORDENAÇ̃̃O ACADÊMICA
}

\author{
Prof. Luiz Eduardo Gouvêa Alves
}

Livre-docente em Administração pela Universidade de Franca.

especializacao@estacio.br

\section{OBJETIVOS}

- Aprofundar a percepção da moderna concepção dos sistemas integrados, suas interações com a comunidade e com as noções holísticas de qualidade de vida como fator de desenvolvimento e competitividade.

- Capacitar profissionais para um novo mercado em que uma crescente demanda de perfil empreendedor está focada para o trinômio: qualidade de vida, recursos renováveis, responsabilidade social, ergonomia e segurança (O Ser Humano Integral).

- Proporcionar informações para o desenvolvimento de empreendimentos próprios com a utilização da metodologia pertinente a auditorias em sistemas de qualidade e produtividade sem perder de vista a sustentabilidade.

- Possibilitar a utilização de modelos de Gerenciamento de Projetos.

\section{PRE-REQUISITO}

Diploma de curso superior.

\section{PÚBLICO-ALVO}

Profissionais e demais interessados em atuar na área de qualidade e produtividade que exerçam atividades gerenciais.

\section{DISCIPLINAS}

- Síntese Histónica dos Processos de Qualidade e Produtividade - $24 \mathrm{~h} / \mathrm{a}$ sintese histórica dos processos de Qualidade. Educação e treinamento. As mudanças técnicoestruturais (Reengenharia. Benchmark. ABC, ABV e TQM). Qualidade em serviços. A gestão da mudança e as estratégias de implantação. Planejamento multifuncional de Qualidade e Produtividade. Gestão integrada, seus aspectos e tendências. Ergonomia e conforto. Análise de risco, segurança, ambiente e Responsabilidade Social.

\section{O Ser Humano, a Empresa e a Responsabilidade Social - 24 h/a}

As Organizações do século XXI. O homem, suas relações de trabalho e o ambiente empresarial. $\mathrm{O}$ ser humano face às mudanças de comportamento. Comportamento Humano. Sistemas de Motivação Humana. Teorias de Motivação. Componentes do Processo da Negociação organizacional. Gestão de Conflito Motivacional. O ser Humano, sua interação com programas de excelência. Gestão de Pessoas. 
A melhoria do processo e o tratamento das não-conformidades. O PDCA. Metodologia para a Análise e para a Solução de Problemas Gerenciais.

\section{Ferramentas da Qualidade - $\mathbf{2 4}$ h/a}

Ferramentas Básicas: Brainstorming. Votação múltipla. Técnicas de grupo nominal. Diagramas de causa e efeito. Fluxogramas. Análise de campos de força. Matriz GUT. Coleta de dados. Folha de verificação. Estratificação. Diagrama e análise de Pareto. Histograma. Box-plot. Matriz 5W - 1H. Ferramentas gerenciais: Diagrama de seta. Diagrama KJ. A matriz em "T". Pentagrama. Diagrama das relações. Diagrama de afinidades.

\section{Recrutamento, Seleção e Qualidade de Vida - 24 h/a}

O que é Qualidade de Vida? Qualidade de Vida no Trabalho. Modelos de recrutamento e seleção de pessoas. Características do Exame Admissional. Cargos: habilidades e características. Progressão na carreira. Conceitos de função e atribuições funcionais. $O$ "Empowerment". O Capital Intelectual das empresas e de seus profissionais. Recompensas e penalidades. A terceirização e suas características. A quarterização e suas características. $O$ trabalho temporário. Vínculos empregatícios.

\section{Modelos Ambientais e Análise e Prevenção do Risco - 24 h/a}

Conceitos básicos de Hidrologia: O Ciclo Hidrológico; parâmetros de qualidade de águas e a Resolução n 20/86 do CONAMA. A evolução histórica da gestão dos recursos hídricos no mundo e no Brasil. O modelo de gestão através do mercado de águas. Os modelos de gestão negociada e integrada. O modelo francês. O caso brasileiro. A Política Nacional de Recursos Hídricos - Lei $n^{\circ} 9.433 / 97$, seus fundamentos, objetivos, diretrizes gerais. A estruturação politico-institucional do sistema de gestão de recursos hídricos brasileiros: o Conselho Nacional de Recursos Hídricos, a Secretaria de Recursos Hídricos, os Comitês de Bacias Hidrográficas e as Agências de Bacia. Os instrumentos da Lei $n^{\circ}$ 9.433/97: os planos diretores, o sistema de informação, o enquadramento dos corpos de água em classes, a outorga de direito de uso e a cobrança pela água bruta. A Agência Nacional de Águas - ANA - Lei $\mathrm{n}^{\circ}$ 9.984/00. Modelagem Ambiental. Conceituações: impacto, meio ambiente, sociedade. Problemas socioambientais. Indicadores de impacto. Custos ecológicos e sociais. Planejamento. Sistema de Gestão Ambiental - SGA. Atividades Industriais de Produção. Avaliação de Impactos Ambientais de Empreendimentos. Aspectos de Impactos. Análise de Risco Industrial, Tecnológico e Ambiental. Estudo de Caso - Elaboração de Estudo Ambiental de Diagnóstico Ámbiental. Avaliação. Participação da comunidade.

\section{$\square$ Sistemas ISO - $24 \mathrm{~h} / \mathrm{a}$}

Normas série ISO 9000. Normas série ISO 14000. Modelos de Normalização e Auditoria. Normas e Procedimentos Operacionais. Estudos de caso. Modelos preconizados. Comentários sobre modelos de gestão integrada.

\section{CARGA HORÁRIA TOTAL}




\section{Faculdade de Engenharia Mecânica Mestrado Profissional Unicamp Gestão da Qualidade Total}

\section{Objetivos}

O curso de Mestrado Profissional é dirigido aos profissionais da área de Engenharia e Administração de Empresas. O programa visa a preparação de profissionais para atuar em Planejamento, Controle e Melhoria da Qualidade, aplicado às organizações produtivas. Os cursos são flexíveis e visam uma atualização científica e tecnológica necessária à formação de lideranças no setor produtivo. O curso proporciona a seus alunos uma visão especializada e multidisciplinar na área de Qualidade, com a formação e treinamento voltados a problemas práticos, garantindo um melhor retorno sobre o investimento na capacitação profissional. Através de uma equipe de professores altamente qualificada, pretende-se transmitir um conjunto de conhecimentos técnicos e práticos específicos, com uma abordagem generalista das tecnologias e conteúdos, possibilitando a retransmissão destes conhecimentos no que se refere à qualificação da mão de obra.

\section{Reconhecimento ( $<$ voltar)}

O Curso de Mestrado Profissional em Engenharia Mecânica foi avaliado e recomendado pela Coordenação de Aperfeiçoamento de Pessoal de Nível Superior (CAPES) e recebeu conceito 5.

\section{Integralização (《< voltar)}

Para conclusão do Curso de Mestrado Profissional em Engenharia Mecânica em qualquer uma de suas áreas, o aluno deverá perfazer o total de 90 créditos, equivalentes a 1350 horas de atividades.

o Curso Mestrado Profissional em Engenharia Mecânica é constituído de:

- Um módulo compreendendo um total de 6 disciplinas, de 9 créditos cada uma, completando um total de 54 créditos;

- Redação do trabalho final escrito, perfazendo 36 créditos;

- Exame de proficiência em lingua estrangeira;

- Apresentação e defesa do trabalho final perante uma banca examinadora.

Aos participantes que finalizarem o curso completo (módulo de disciplinas, exame de qualificação, exame de proficiência, redação e apresentação à banca examinadora do trabalho final), será outorgado o título de Mestre Profissional em Gestão da Qualidade Total. O prazo de conclusão pode variar de 12 até 24 meses, de acordo com a disponibilidade e a dedicação do participante.

\section{Descrição do Curso (《<voltar)}

O curso será desenvolvido através da realização de um conjunto de módulos, constituído de disciplinas básicas e aplicadas, permitindo a montagem de um programa com currículo flexivel, que atende as necessidades de capacitação do profissional, garantindo assim, uma formação focada a uma determinada área de atuação.

Esses módulos serão constituídos de um conjunto sinérgico de disciplinas oferecidas ao longo do ano, em sala de aula ou laboratório. Estes módulos poderão também ser direcionados a aplicações específicas, em função das necessidades da empresa interessada no curso, com as adaptações que se fizerem necessárias. 
Todas as disciplinas serão ministradas por professores do corpo docente do curso de Pós-graduação da Faculdade de Engenharia Mecânica da UNICAMP.

As aulas teóricas poderão ser realizadas na UNICAMP ou na empresa. O mesmo acontecerá com os trabalhos práticos, conforme o acordo preestabelecido entre a empresa e a coordenação do curso.

A Faculdade de Engenharia Mecânica da UNICAMP possui auditórios e salas especialmente preparados com equipamentos para a realização dessas aulas teóricas, tais como retroprojetores, telas, projetores de slides, vídeos, etc, que serão colocados à disposição dos docentes responsáveis dos cursos.

As aulas práticas serão desenvolvidas utilizando a infra-estrutura de laboratórios existentes na FEM/UNICAMP, podendo uma parte ser desenvolvida em cooperação com o setor produtivo.

No final da realização, pelo aluno, do conjunto de disciplinas constituintes do curso, o mesmo deverá realizar o trabalho final com orientação de um professor do curso. Todo aluno terá um professor orientador da FEM, e no caso de um determinado curso ser oferecido na indústria, o aluno poderá ter um co-orientador na indústria.

\section{Elenco das disciplinas do Mestrado Profissional em Gestão da Qualidade Total $(<<$ voltar)}

MR 144 Redação Cientifica

MR 250 Fundamentos da Gestão da Qualidade Total

MR 251 Técnicas para Gestão da Qualidade Total

MR 252 Fundamentos de Técnicas Estatísticas Aplicadas

MR 253 Técnicas Estatísticas para Gestão da Qualidade Total

MR 254 Normas da Qualidade e Prêmios da Qualidade

MR 255 Sistemas de Informação e sistemas da Qualidade

MR 256 Tópicos de Gestão da Qualidade Total

MR 257 Estudos Orientados para Dissertação sobre Qualidade

\section{Contatos («< volitar)}

Universidade Estadual de Campinas

Faculdade de Engenharia Mecânica

Comissão de Pós-Graduação/Mestrado Profissional

Caixa Postal 6122 - CEP 13083-970 - Campinas - SP

Tel.: (0XX19) 3788-3229 Fax: (0XX19) 3289-3722

e-mail:mprof@rem.unicamo.br 


\title{
Fundação Escola de Sociologia e Política de São Paulo Escola Pós-Graduada de Ciências Sociais \\ Curso de Especialização - lato sensu: \\ Gerência de Sistemas e Serviços de Informação
}

\author{
Disciplina: Gestão da Qualidade em Serviços de Informação (GQSI) \\ Carga Horária: 32 Horas/Aula \\ Profa Dra Responsável: Valéria Martin Valls \\ Titulação: Doutora e Mestre em Ciências da Comunicação pela ECA/USP
}

\section{Programa de Disciplina}

\section{Ementa:}

A Gestão da Qualidade tornou-se uma tendência mundial na administração das mais diversas Organizações. Embora a história do movimento da qualidade esteja relacionada diretamente às práticas industriais, ela vem sendo implantada com sucesso na área de serviços, principalmente em razão de suas características e da peculiaridade de seus clientes, que não adquirem um bem tangivel e sim algo intangível, que depende diretamente da interação de seres humanos.

Com o advento das normas da série ISO 9000, a implantação de Sistemas de Gestão da Qualidade teve um grande impulso e atualmente implantar e manter um sistema baseado nestas normas deixou de ser um diferencial competitivo para tornar-se condição básica nas relações comerciais internacionais, especialmente com a globalização de mercados.

Especialmente na área de Serviços de Informação, a literatura está repleta de experiências e trabalhos teóricos buscando analisar a administração de bibliotecas, centros de informação, arquivos técnicos e demais serviços a partir dos fundamentos e conceitos da Gestão da Qualidade.

Conhecer seus fundamentos e sua aplicabilidade nos Serviços de Informação é fundamental para que o Profissional da Informação implante e gerencie estes serviços de forma integrada e alinhada à Política da Instituição mantenedora.

\section{Objetivos:}

Dentro do enfoque apresentado, o Curso tem como objetivo apresentar os fundamentos da Gestão da Qualidade, sua aplicação na área de serviços e especificamente a Qualidade em Serviços de Informação. Complementando a base teórica, serão apresentados também os requisitos e princípios da série de normas ISO 9000 . 


\section{Conteúdo Programático:}

- Aspectos conceituais da Gestão da Qualidade: abordagem histórica, fundamentação teórica, conceitos e princípios, ferramentas da qualidade, etc;

- A implantação e certificação de Sistemas de Gestão da Qualidade com base na NBR ISO 9001;

- A Qualidade em Serviços;

- A Gestão da Qualidade em Serviços de Informação.

Critérios de Avaliação:

Leituras dirigidas.

Elaboração e entrega de resenha individual.

Entrega e apresentação de trabalho ou projeto de final do módulo. 